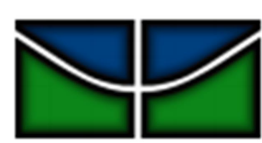

UnB

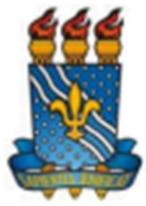

UFPB

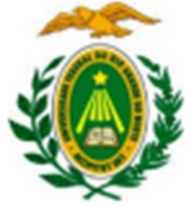

UFRN

UNIVERSIDADE DE BRASÍLIA - UnB UNIVERSIDADE FEDERAL DA PARAÍBA - UFPB

UNIVERSIDADE FEDERAL DO RIO GRANDE DO NORTE - UFRN

Programa MultiInstitucional e Inter-Regional de Pós Graduação em Ciências Contábeis

ANA KARLA DE LUCENA GOMES

DESEMPENHO ORGANIZACIONAL DAS MICRO E PEQUENAS EMPRESAS LOCALIZADAS EM JOÃO PESSOA: Estudo comparativo entre empresas que participam de redes de cooperação e empresas que não participam 


\section{DESEMPENHO ORGANIZACIONAL DAS MICRO E PEQUENAS EMPRESAS LOCALIZADAS EM JOÃO PESSOA: Estudo comparativo entre empresas que participam de redes de cooperação e empresas que não participam}

Dissertação apresentada ao Programa MultiInstitucional e Inter-Regional de PósGraduação em Ciências Contábeis da Universidade de Brasília, Universidade Federal da Paraíba e Universidade Federal do Rio Grande do Norte, em cumprimento às exigências para obtenção do grau de Mestre em Ciências Contábeis.

Orientador: Prof. Dr. Aldo Leonardo Cunha Callado. 
G633d Gomes, Ana Karla de Lucena.

Desempenho organizacional das micro e pequenas empresas localizadas em João Pessoa: estudo comparativo entre empresas que participam de redes de cooperação e empresas que não participam / Ana Karla de Lucena Gomes.João Pessoa, 2016.

113f. : il.

Orientador: Aldo Leonardo Cunha Callado

Dissertação (Mestrado) - UnB-UFPB-UFRN

1. Contabilidade. 2. Desempenho organizacional. 3. Micro e pequenas empresas. 4. Redes de cooperação horizontal. 


\section{DESEMPENHO ORGANIZACIONAL DAS MICRO E PEQUENAS EMPRESAS LOCALIZADAS EM JOÃO PESSOA: Estudo comparativo entre empresas que participam de redes de cooperação e empresas que não participam}

Dissertação apresentada ao Programa MultiInstitucional e Inter-Regional de Pós-Graduação em Ciências Contábeis da Universidade de Brasília, Universidade Federal da Paraíba e Universidade Federal do Rio Grande do Norte, em cumprimento às exigências para obtenção do grau de Mestre em Ciências Contábeis.

\section{COMISSÃO EXAMINADORA}

Prof. Dr. Aldo Leonardo Cunha Callado

Programa Multiinstitucional e Inter-regional de Pós-graduação em Ciências Contábeis da UnB/UFPB/UFRN

Orientador

\section{Prof. Dr. Paulo Roberto Nóbrega Cavalcante}

Programa Multiinstitucional e Inter-regional de Pós-graduação em Ciências Contábeis da UnB/UFPB/UFRN

Membro Examinador Interno

Prof. Dr. Cláudio de Araújo Wanderley

Universidade Federal de Pernambuco - UFPE

Membro Examinador Externo

\section{JOÃO PESSOA}


"Ao Rei eterno, o Deus único, imortal e invisível, sejam honra e glória para todo sempre. Amém.” (1 Timóteo 1:17) 


\section{AGRADECIMENTOS}

Agradeço primeiramente ao Deus todo poderoso, Senhor da minha vida, meu protetor, meu escudo, minha fortaleza, minha torre forte, meu abrigo, meu refúgio, fonte inesgotável de misericórdia. Deus, o Teu amor é infinito e sou eternamente grata a Ti por todas as bênçãos derramadas. Obrigada por me sustentar, me conceder forças e sabedoria na condução deste trabalho e, sobretudo, por Tua graça ter me alcançado.

À minha mãe, Ana Zélia Lucena pelas suas incessantes orações e jejuns, conselhos, apoio e amor. Mãe, obrigada por ser esse exemplo de mulher batalhadora e guerreira, que vai à luta e não desiste dos sonhos. Obrigada pelos ensinamentos e por ter se dedicado sempre em me proporcionar educação de qualidade. Nunca esquecerei a forma como a senhora me alfabetizou em três meses (risos). Te amo!

Ao meu pai, Antônio Gomes, pelo exemplo de homem trabalhador, digno e responsável. Obrigada por ter feito sempre e por continuar fazendo o possível e o impossível para que nada me falte. Deus foi muito generoso comigo quando me concedeu o senhor. Espero poder proporcionar-lhe alegrias através das minhas conquistas. Te amo pai.

À minha irmã, Danielle a quem eu admiro muito pela sua bondade e simplicidade. Mana você é um presente de Deus, além de uma irmã é uma amiga e confidente que me ajuda em todos os momentos em que preciso. Sei que Deus irá lhe retribuir por tudo que tens feito pela nossa família. Te amo sister 52.

Ao meu marido, Nelson Justino, por ter sido a pessoa que me incentivou e influenciou para que eu fizesse o mestrado acadêmico. És um exemplo de profissional, competente e dedicado em quem me espelho. Obrigada pelos momentos em que pode me auxiliar e pela compreensão durante o período em que estive com todas as atenções voltadas para a conclusão desta pesquisa. Lov $u$ !

Ao meu tio Luís, por ser um exemplo de homem de fé em Deus, dedicação e amor. Muitíssimo obrigada pelas suas orações, que o Senhor Jesus lhe abençoe cada dia mais.

A toda família Lucena, muito obrigada pela existência de todos, são sem dúvida a melkivı família do mundo. Em especial para minha "Mainha", a matriarca da família, Dona Dalila, obrigada pelo seu carinho, amor, simplicidade e ensinamentos.

À minha família Gomes, que apesar do distanciamento, sei que torce pelo meu crescimento pessoal e profissional.

Aos contadores do coração, Emiliano, Esthelina, Talita Pires e Talita Torres pela torcida, pelo apoio, cooperação e incentivo. Muito obrigada pela amizade de cada um, vocês são especiais.

Ao meu orientador Dr. Aldo Callado, pela paciência, compreensão e apoio concedido para concretização deste trabalho. Obrigada.

A todos os professores do Programa Multiinstitucional e Inter-regional de Pós-graduação em Ciências Contábeis, pelo aprendizado em sala de aula: Dra. Aneide Araújo, Dr. Wenner Lucena, Dr. Edilson Paulo, Dr. Paulo Amilton, Dra. Márcia Reis, Dr. Adilson de Lima, Dr. Adriano Paixão, Dr. Aldo Callado, Dr. Paulo Aguiar e Dr. Paulo Roberto. 
Aos colegas da turma 28: Inajá, André, Marcelo, Camila, Agamenon, Leandro, Roberto, Vitor Godeiro, Victor Ranieri, Polyandra e João Marcelo. Aprendi muito com cada um de vocês. Agradeço em especial a Fabiana, por ter me recebido em sua casa durante as disciplinas em Natal, muito obrigada pela hospitalidade.

Às secretárias Iva e Wilma, com quem pude contar sempre que precisei. Parabéns pela competência e dedicação ao trabalho.

À Coordenação de Aperfeiçoamento de Pessoal de Nível Superior (Capes), pela bolsa de estudo concedida. 


\section{RESUMO}

Tendo em vista a série de acontecimentos que advém da virada do século e que representam desafios para o mercado tornando sua dinâmica mais rápida, há a necessidade por parte das organizações de implementar práticas que possam assegurar a sua sobrevivência e competitividade. Especialmente nas micro e pequenas empresas (MPEs) em que a competição globalizada apresenta-se desvantajosa quando comparadas às médias e grandes empresas, é possível utilizar mecanismos que possibilitem a busca por diferenciais competitivos, a exemplo da inserção da empresa em uma rede de cooperação. Muitos são os estudos que reconhecem os motivos e benefícios das estratégias cooperativas, no entanto, poucos são os que se propõe a comparar o desempenho organizacional das empresas cooperadas versus as empresas que não participam de nenhuma relação interorganizaconal. Dessa forma, o presente estudo teve como objetivo verificar se as MPEs inseridas em redes horizontais de cooperação apresentam desempenho organizacional superior àquelas que atuam independente de qualquer relação interorganizacional, através da percepção do gestor. Por meio de uma survey com 67 MPEs inseridas em redes de cooperação e 154 MPEs não cooperadas analisou-se o desempenho organizacional com base na percepção do respondente a respeito de aspectos associados às medidas de desempenho: satisfação dos clientes; satisfação dos funcionários; crescimento da empresa; lucratividade da empresa e desempenho geral. Os resultados analisados por meio do teste de Mann-Whitney indicam que, de acordo com a percepção do gestor, as empresas inseridas em redes de cooperação apresentam desempenho organizacional maior quando confrontadas com as empresas não cooperadas. Adicionalmente, verificou-se que o fato de uma empresa ser de determinado segmento ou possuir certa quantidade de funcionários, influencia na ocorrência desta ser ou não uma MPE cooperada.

Palavras-Chaves: Desempenho Organizacional. Micro e Pequenas Empresas. Redes de Cooperação Horizontal. 


\begin{abstract}
In view of the series of events that came from the turn of the century and represent challenges for the market since it makes their dynamic faster, there is a need for organizations to implement practices to ensure their survival and competitiveness. Especially for micro and small enterprises (MSEs) in which the global competition presents disadvantageous when compared to the medium and large enterprises, it is possible to use mechanisms that enable the search for competitive advantages, such as the company's inclusion in a network of cooperation. There are many studies that recognize the reasons and the benefits of cooperative strategies, however, there are few that aims to compare organizational performance of cooperative companies versus companies that do not participate in any interorganizational relationship. Thus, this study aimed to verify if the MSEs inserted in horizontal cooperation networks have superior organizational performance to those that operate without any interorganizational relationship, through manager's perception. Through a survey with 67 MSEs inserted in cooperation networks and 154 MSEs not cooperated, it was analyzed the organizational performance based on the perception of the respondent regarding aspects associated with performance measures: customers satisfaction; employees satisfaction; growth of the company; company profitability and overall performance. The results analyzed using the Mann-Whitney test indicate, through manager's perception, that the companies entered into cooperation networks have higher organizational performance when compared to noncooperative companies. Additionally, it was found that the fact of a company being part of a certain segment or having a certain number of employees, influences the occurrence of it to be or not a cooperative MSE.
\end{abstract}

Keywords: Organizational performance. Micro and small enterprises. Horizontal cooperation networks. 


\section{LISTA DE QUADROS}

Quadro 1: A contribuição das MPEs para o desenvolvimento econômico.

Quadro 2: Aspectos que caracterizam as três fases do processo de cooperação

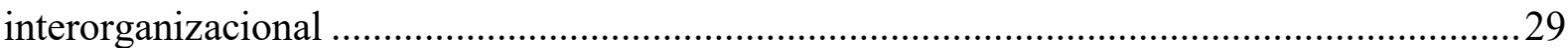

Quadro 3: Descrição dos tipos de relação interorganizacional desenvolvidos a partir do Mapa de Orientação Conceitual de Marcon e Moinet ....................................................................... 33

Quadro 4: Operacionalização das Variáveis de Medição do Desempenho Organizacional a

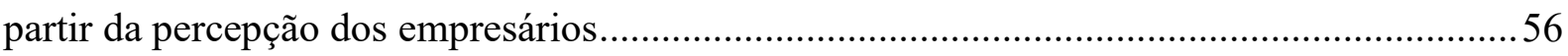

Quadro 5: Composição do escore total para medição do desempenho total...........................57 


\section{LISTA DE TABELAS}

Tabela 1: Universo de Redes de Cooperação localizadas no estado da Paraíba 50

Tabela 2: Universo e amostra da pesquisa

Tabela 3: Perfil das empresas cooperadas e não cooperadas e resultados do teste Quiquadrado

Tabela 4: Análise de Correspondência Múltipla para a tabela multidimensional Porte $\mathrm{x}$ Segmento x Grupo com solução completa em sete dimensões

Tabela 5: Medidas descritivas do perfil da empresa e seus testes de Mann-Whitney para comparação dos grupos das empresas cooperadas e não cooperadas.

Tabela 6: Perfil do respondente das empresas cooperadas e não cooperadas e resultados do teste Qui-quadrado.

Tabela 7: Medidas descritivas do perfil do respondente e seus testes de Mann-Whitney para comparação dos grupos de empresas cooperadas e não cooperadas

Tabela 8: Medida de fidedignidade Alfa de Cronbach para o desempenho organizacional em comparação aos concorrentes correspondente a cada item ausente e para todos os itens com seu intervalo de confiança

Tabela 9: Medidas descritivas do desempenho organizacional medido pela satisfação dos clientes em comparação aos concorrentes e respectivos testes de Mann-Whitney para comparação das empresas cooperadas e não cooperadas

Tabela 10: Medidas descritivas do desempenho organizacional medido pela satisfação dos funcionários em comparação aos concorrentes e respectivos testes de Mann-Whitney para comparação das empresas cooperadas e não cooperadas

Tabela 11: Medidas descritivas do desempenho organizacional medido pelo crescimento da empresa em comparação aos concorrentes e respectivos testes de Mann-Whitney para comparação das empresas cooperadas e não cooperadas

Tabela 12: Medidas descritivas do desempenho organizacional medido pela lucratividade da empresa em comparação aos concorrentes e respectivos testes de Mann-Whitney para comparação das empresas cooperadas e não cooperadas

Tabela 13: Medida de fidedignidade Alfa de Cronbach para o desempenho organizacional em comparação ao ano anterior correspondente a cada item ausente e para todos os itens com seu intervalo de confiança 
Tabela 14: Medidas descritivas do desempenho organizacional medido pelo crescimento da empresa em comparação ano anterior e respectivos testes de Mann-Whitney para comparação das empresas cooperadas e não cooperadas 82

Tabela 15: Medidas descritivas do desempenho organizacional medido pela lucratividade da empresa em comparação ano anterior e respectivos testes de Mann-Whitney para comparação das empresas cooperadas e não cooperadas

Tabela 16: Medida de fidedignidade Alfa de Cronbach para o desempenho organizacional geral correspondente a cada item ausente e para todos os itens com seu intervalo de confiança

Tabela 17: Medidas descritivas do desempenho organizacional medido pelo desempenho geral e respectivos testes de Mann-Whitney para comparação das empresas cooperadas e não cooperadas 86

Tabela 18: Desempenho organizacional medido pelo escore de todos os escores das medidas descritivas e respectivos testes de Mann-Whitney para comparação das empresas cooperadas e não cooperadas 


\section{LISTA DE GRÁFICOS}

Gráfico 1: Desempenho medido pela satisfação dos clientes das empresas cooperadas e não cooperadas em comparação aos concorrentes e seus níveis de satisfação

Gráfico 2: Desempenho medido pela satisfação dos funcionários das empresas cooperadas e não cooperadas em comparação aos concorrentes e seus níveis de satisfação

Gráfico 3: Desempenho medido pelo crescimento nas empresas cooperadas e não cooperadas em comparação aos concorrentes e seus níveis de satisfação

Gráfico 4: Desempenho medido pela lucratividade nas empresas cooperadas e não cooperadas em comparação aos concorrentes e seus níveis de satisfação 80

Gráfico 5: Desempenho medido pelo crescimento das empresas cooperadas e não cooperadas em comparação ao ano anterior e seus níveis de satisfação

Gráfico 6: Desempenho medido pela lucratividade das empresas cooperadas e não cooperadas em comparação ao ano anterior e seus níveis de satisfação

Gráfico 7: Desempenho medido pelo desempenho geral das empresas cooperadas e não cooperadas em comparação ao ano anterior e seus níveis de satisfação 


\section{LISTA DE FIGURAS}

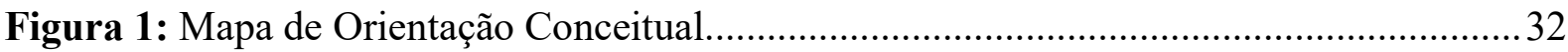

Figura 2: Representação das categorias de grupos de empresas cooperadas e não cooperadas $\mathrm{X}$ Porte da empresa X Segmento da empresa no plano bidimensional ..................................64 


\section{LISTA DE SIGLAS E ABREVIAÇÕES}

MEI

Microempreendedores Individuais

MPEs

Micro e Pequenas Empresas

ONU

Organização das Nações Unidas

PRC

Programa Redes de Cooperação

SEBRAE

Serviço de Apoio a Micro e Pequenas Empresas

SEDAI

Secretaria do Desenvolvimento e dos Assuntos Internacionais 


\section{SUMÁRIO}

1 CAPÍTULO I: INTRODUÇÃO ........................................................................16

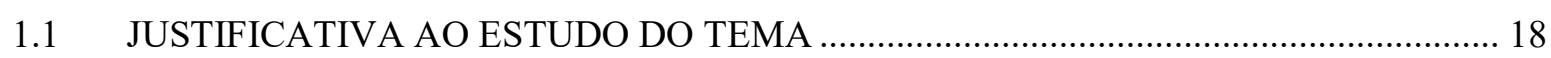

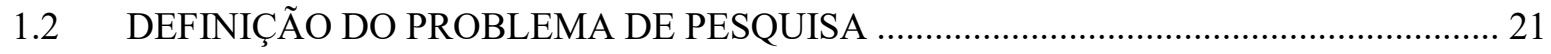

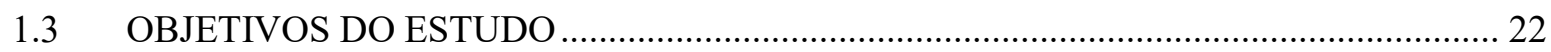

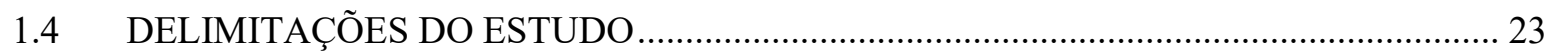

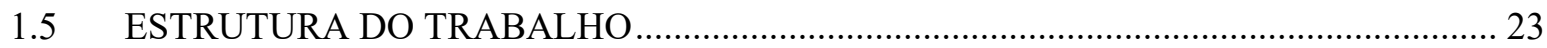

2 CAPÍTULO II: REFERENCIAL TEÓRICO ............................................................25

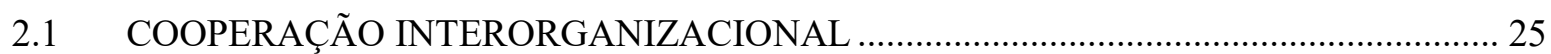

2.2 TIPOLOGIAS DE RELAÇÕES INTERORGANIZACIONAIS ......................................... 30

2.3 REDES HORIZONTAIS DE COOPERAÇÃO INTERORGANIZACIONAL .................... 34

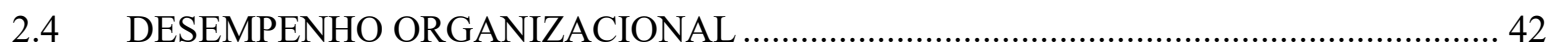

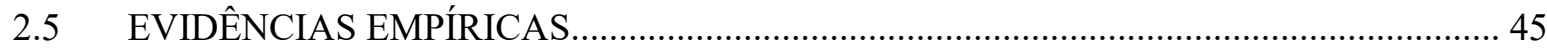

3 CAPÍTULO III: PROCEDIMENTOS METODOLÓGICOS .......................................49

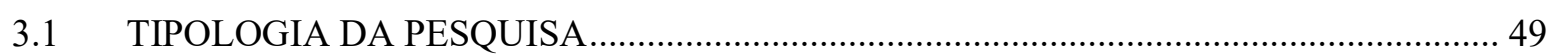

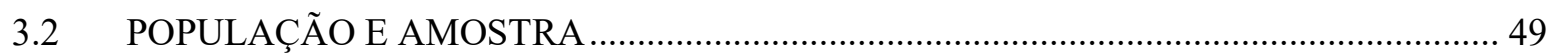

3.3 INSTRUMENTO DE PESQUISA E PROCEDIMENTOS DE COLETA DE DADOS ...... 52

3.4 HIPÓTESE E OPERACIONALIZAÇÃO DAS VARIÁVEIS ............................................... 55



\section{CAPÍTULO IV: APRESENTAÇÃO E DISCUSSÃO DOS RESULTADOS DA}

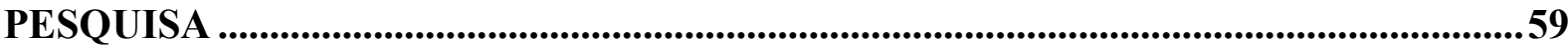

4.1 CARACTERIZAÇÃO DAS EMPRESAS PARTICIPANTES DA PESQUISA .................. 59

4.2 CARACTERIZAÇÃO DO PERFIL DO RESPONDENTE …………….............................. 66

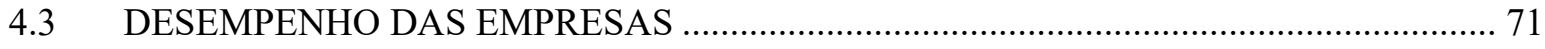

4.3.1 Desempenho organizacional em comparação aos concorrentes............................. 72

4.3.2 Desempenho em comparação ao ano anterior ……................................................ 81

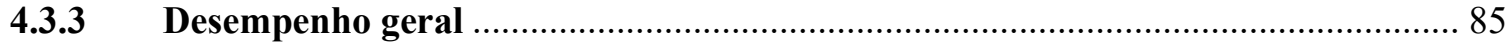

4.3.4 Escore para todas as medidas de Desempenho Organizacional ............................. 87

5 CAPÍTULO V: CONSIDERAÇÕES FINAIS ...........................................................89

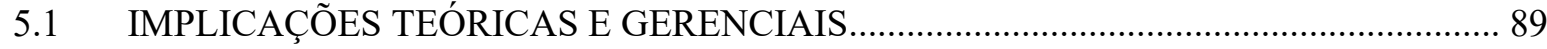

5.2 LIMITAÇÕES E SUGESTÕES PARA PESQUISAS FUTURAS....................................... 90

APÊNDICE A: QUESTIONÁRIO .................................................................................... 106 


\section{CAPÍTULO I: INTRODUÇÃO}

A virada do século XXI foi marcada por acontecimentos que denotam desafios de alto impacto para o mercado. Eventualidades, tais como: crise econômica em dimensões globais, mudanças climáticas, alterações em condições de desigualdade social, bem como o aparecimento de novos mercados, acompanhado de consumidores ainda mais meticulosos (MATITZ, 2009).

Além disso, sabe-se que o mundo empresarial há tempos é caracterizado pela globalização. Esta, por sua vez, corresponde à facilidade como concorrentes, fornecedores e

clientes que estão distribuídos pelo mundo se conectam e interagem. Por exemplo, a impressão de uma revista francesa pode ser editada na Bélgica, com papel oriundo do Canadá, contendo anúncios para aparelhos eletrônicos que, por sua vez, foram idealizados no Japão, fabricados em Taiwan, segurados em Hong Kong, e vendidos por uma varejista multinacional britânica das quais se utiliza de personagens de desenhos animados americanos para o marketing (ACS; MORCK; YEUNG, 2001).

Desta forma, a globalização consiste em um complexo processo de integração global, em que as fronteiras territoriais não representam obstáculo para comunicação. O progresso tecnológico, por sua vez, possui parcela contributiva para o estreitamento dos laços entre pessoas de todo o mundo, além disso, tem-se a diminuição nos custos dos transportes, auxiliando, também, no referido processo (UTKIN, 2002).

Adicionalmente, a globalização implica em mudanças na sociedade como um todo, especialmente nos mercados, tornando a dinâmica dos negócios mais rápida. É possível mencionar, por exemplo, o aumento da competitividade como um dos fatores que emerge devido ao sistema global, exigindo que algumas empresas unam esforços com outras companhias para garantir a sobrevivência (ACS et al., 2002).

Juntamente com a competitividade, há uma preocupação generalizada com a inovação, bem como com a forma mais eficiente de "fazer negócio". Anteriormente, fatores que eram considerados inovadores e criativos, a exemplo de qualidade e custo baixo, e que serviam como obtenção de vantagens competitivas foram transformados em requisitos básicos para as empresas ingressarem no mercado (MOTTA, 1995).

Dessa forma, as organizações necessitavam de novas ferramentas e técnicas para sobressair-se em meio à ampla concorrência, sendo uma das soluções encontradas para aplacar o problema, a formação de redes de cooperação. De acordo com Olave e Amato Neto (2001), esta corresponde a uma prática que projeta assegurar a sobrevivência e 
competitividade, em especial de pequenas e médias empresas, de maneira que uma nova estrutura organizacional seja formada e o relacionamento entre empresas seja inovado.

Para micro e pequenas empresas (MPEs), a competição globalizada que domina a sociedade capitalista apresenta-se ainda mais desigual, sobretudo quando considerado fatores limitantes das pequenas empresas, a exemplo de baixo volume de compras, limitando a capacidade de negociação com os fornecedores, custos incorridos com publicidade e treinamento de funcionários, custos de participação em feiras, atualização tecnológica, acesso a linhas de crédito e financiamentos, entre outros fatores que dificultam a capacidade competitiva dessas organizações (TURETA; PAÇO-CUNHA, 2008).

Além disso, tem-se a crescente migração de empresas estrangeiras para diversos países, sobretudo aqueles em desenvolvimento, a exemplo do Brasil, exigindo das empresas nacionais uma nova postura frente ao atual cenário competitivo. Dessa forma, as grandes organizações já fixadas em território brasileiro buscam novas alternativas para sobressair-se e acabam explorando mercados que até então eram ocupados apenas por MPEs (TURETA; PAÇO-CUNHA, 2008).

Observa-se, pois, que o cenário não se mostra favorável à sobrevivência das MPEs, tendo em vista a pressão dos fornecedores, clientes e concorrentes. Por conseguinte, a exposição individual destas, pode acarretar em sua assolação devido à ameaça gerada pelas grandes organizações (CASAROTTO FILHO; PIRES, 2001).

Verschoore e Balestrin (2006) afirmam que a cooperação em rede representa uma possibilidade, no campo de gestão de MPEs, que deve ser ponderada quando se tratar da busca por diferenciais competitivos. Isso porque as redes possuem características que suprem as necessidades competitivas mais facilmente, a exemplo da união entre competição e cooperação, escala e escopo e hierarquia com mercado (CICCHETTI, 2003).

Tavares e Castro (2002) destacam que a condição de cooperar é considerada como elemento-chave nas relações interorganizacionais. Os pressupostos e elementos de cooperação são a base para a idealização das redes, de forma que as empresas que a compõe veem na supracitada cooperação uma saída para alcançar resultados mais satisfatórios no mercado, além da expectativa de aperfeiçoar ou angariar recursos (TAVARES; CASTRO, 2002; WEGNER; MAEHLER, 2012).

Os acordos de cooperação entre firmas existem há séculos. Porém, até os anos 80 , estes não eram considerados benéficos, visto que ao se falar em cooperação, acordos como os cartéis eram os mais citados. O cenário passa a se transformar com o advento da globalização e consequente modificação de paradigma tecnológico. De maneira que a cooperação passa a 
ser encarada mais pela sua qualidade "benévola" de pactos que visam à inovação (GRASSI, 2007).

Pode-se considerar então que a cooperação entre firmas constitui-se uma alternativa, aparentemente viável, para atuação das empresas, especificamente MPEs. Principalmente em um ambiente de concorrência acirrada e globalização dos mercados, a união de esforços pode ser uma estratégia para enfrentar a competitividade. Desta feita, sabe-se que o fator impulsionador para cooperação entre as empresas é a concorrência entre aquelas que não estão inseridas na rede.

Em razão das condições de concorrência enfrentadas pelas empresas, sobretudo pelas MPEs frente às grandes organizações, sobressairão aquelas que apresentarem um comportamento inovador, intrépido e disposto à cooperação. Para isto, faz-se necessário a quebra de paradigmas observados, por vezes, como características de MPEs, a exemplo da ausência de inovação, carência de capacitação, centralização de atividades, entre outros (LIEDHOLM; MEAD, 1999).

Portanto, a inserção de uma MPE em uma rede de cooperação representaria uma oportunidade para a conquista de melhores condições de competição, uma vez que, a entrada na referida rede ocasionaria a extinção daquelas características citadas como barreiras à sobrevivência em um mercado competitivo. Aliado a isso, a constituição das redes de cooperação transfigura-se na possibilidade das empresas se organizarem para competição nos níveis local, regional e global, de forma que os custos e os investimentos, os riscos e as incertezas do mercado global seriam minimizados. (VERSCHOORE FILHO, 2006; ALVES et al., 2010).

\subsection{JUSTIFICATIVA AO ESTUDO DO TEMA}

De acordo com o exposto, é possível considerar que as relações interorganizacionais representam uma estratégia para empresas de qualquer porte, em especial para garantir a sobrevivência das MPEs. No Brasil, assim como em outros países, percebe-se a crescente adesão das organizações ao movimento da cooperação interorganizacional que, por sua vez, possui variedade em suas formas de relação (WEGNER, 2011). O presente estudo, por exemplo, tem como objeto de análise as redes horizontais de cooperação que correspondem às relações entre organizações que competem no mesmo mercado. Relações estas em que a independência individual de cada empresa é preservada e não há nenhuma empresa líder que 
direcione a gestão da rede. Observa-se, pois, relações simétricas entre os participantes de uma rede de cooperação que optam por se unir para empregar atividades conjuntas e alcançar vantagens competitivas.

Conforme afirmam Balestrin e Verschore (2010), as pesquisas a respeito das redes de cooperação interorganizacional vêm se desenvolvendo e ganhando espaço notório nos estudos organizacionais nacionais. Os autores justificam este acontecimento a partir de dois fatores, a saber: o primeiro diz respeito ao entendimento que a academia brasileira obteve, em concordância com as teorias contempofrâneas sobre estudos organizacionais, de que a mesma é, sobremaneira, influenciada pela dinâmica do relacionamento cooperador, bem como pelas relações que a organização possa constituir. O segundo diz respeito à importância econômica e social que a constituição de redes de cooperação vem manifestando no País, principalmente no que se refere à sustentação, fortalecimento e progresso das MPEs.

Entende-se que a relevância das MPEs, bem como sua ingerência sobre economias, regiões e sociedades é expressiva. Estas, por sua vez, exercem uma influência significativa sobre as economias de muitos países através de sua capacidade de inovar produtos e processos e tem sido o motor do crescimento econômico e do progresso tecnológico (BRUQUE; MOYANO, 2007; GEROLAMO et al., 2008).

Bratu (2007) discorre acerca da contribuição concedida ao bem-estar econômico do país pelas MPEs, principalmente no que diz respeito à força do mercado de trabalho e da geração do valor acrescentado bruto. Igualmente, Liedholm e Mead (2013) corroboram ao destacar a importância das MPEs no âmbito socioeconômico, afirmando que a contribuição destas para a criação de empregos e para redução da pobreza, tem sido reconhecida por muitos governos de países em desenvolvimento. Ainda de acordo com os autores, as MPEs podem auxiliar a expansão econômica por meio de diversas formas que, por sua vez, são elencadas no Quadro 1.

Conforme destacado, as redes de cooperação são consideradas um refúgio para as organizações que necessitam posicionar-se competitivamente no mercado e buscar sua sobrevivência e fortalecimento. Desta maneira, entende-se que estudos que busquem compreender, mesmo que indiretamente, se tais alternativas de subsistir são, de fato, viáveis para as MPEs se fazem necessários quando a relevância destas na esfera econômica é compreendida. Sendo assim, do ponto de vista social, a pesquisa justifica-se por investigar aspectos relacionados às MPEs. 
Quadro 1: A contribuição das MPEs para o desenvolvimento econômico

\begin{tabular}{|c|l|}
\hline Contribuição & \multicolumn{1}{c|}{ Implicação } \\
\hline $\begin{array}{c}\text { Para a renda familiar e } \\
\text { bem-estar }\end{array}$ & $\begin{array}{l}\text { (a) Fornecimento de manutenção de renda para aqueles com poucas opções; } \\
\text { (b) Fornece uma base para o crescimento da renda e bem-estar através da } \\
\text { acumulação de ativos, desenvolvimento de habilidades, e acesso a oportunidades } \\
\text { econômicas mais gratificantes; } \\
\text { (c) Geração de emprego }\end{array}$ \\
\hline $\begin{array}{c}\text { Para a autoconfiança e } \\
\text { fortalecimento do } \\
\text { indivíduo }\end{array}$ & $\begin{array}{l}\text { (a) O reconhecimento da dignidade da pessoa humana; } \\
\text { (b) Difundir a visão de que a mudança é possível }\end{array}$ \\
$\begin{array}{c}\text { Para a mudança social, a } \\
\text { estabilidade política e } \\
\text { democracia }\end{array}$ & $\begin{array}{l}\text { (a) Através do aumento da confiança no local, representante, as instituições de } \\
\text { base comunitária; } \\
\text { (b) Através do desenvolvimento de sensações individuais de responsabilidade e } \\
\text { participação no governo; } \\
\text { (c) Mediante a criação de estruturas institucionais refletindo as necessidades e } \\
\text { objetivos das pessoas }\end{array}$ \\
\hline $\begin{array}{c}\text { Para os objetivos de } \\
\text { distribuição ou de } \\
\text { desenvolvimento }\end{array}$ & $\begin{array}{l}\text { (a) Proporcionar novas oportunidades para os pobres; } \\
\text { (b) Proporcionar novas oportunidades para as mulheres; } \\
\text { (c) Proporcionar novas oportunidades para quem vive em áreas rurais, e em } \\
\text { locais isolados }\end{array}$ \\
\hline $\begin{array}{c}\text { Na área das mudanças } \\
\text { demográficas }\end{array}$ & $\begin{array}{l}\text { (a) Através da redução das taxas de natalidade; } \\
\text { (b) Por meio da redução da migração rural-urbana }\end{array}$ \\
\hline
\end{tabular}
Fonte: Adaptado de Liedholm e Mead (2013)

De acordo com a perspectiva teórica, o presente trabalho busca exibir um estudo voltado para o levantamento de dados perscrutadores acerca de um conhecimento pouco explorado. Enquanto que a maioria dos estudos discorre a respeito das vantagens de uma empresa ser participante de uma rede de cooperação, há poucos estudos que se propõe a confrontar o desempenho organizacional de MPEs inseridas em uma rede de cooperação versus àquelas que atuam independente de qualquer relação interorganizacional. Portanto, a obtenção e análise crítica dos resultados a serem obtidos neste plano de trabalho subsidiarão a disponibilidade de informações teóricas ainda escassas.

Além dos fatores já mencionados, pode-se elencar, também, a contribuição potencial para o meio econômico, visto que, é esperado, especialmente, que as descobertas da pesquisa que serão relatadas, bem como o aprofundamento teórico sobre redes de cooperação, consentirão, possivelmente, o aperfeiçoamento das ferramentas de gestão, possibilitando ao empresário melhor entendimento acerca do seu negócio. Desta forma, tais informações poderão subsidiar a projeção de respostas estratégicas para cada tipo de empresa analisada (participante ou não de uma rede de cooperação) de maneira a estimular a competitividade dos pequenos negócios.

Considerando os aspectos supracitados, o presente trabalho se justifica ainda por investigar além dos estudos que retratam os aspectos benéficos trazidos a partir da participação em rede de cooperação, mas que não constatam se tais resultados são, de fato, 
significativamente satisfatórios quando comparados àqueles obtidos por empresas não integrantes de uma rede de cooperação. Além disso, a pesquisa gera informações a gestores de redes, empresários e acadêmicos, acerca do estabelecimento de relações interorganizacionais.

\subsection{DEFINIÇÃO DO PROBLEMA DE PESQUISA}

O cenário econômico atual exige das empresas habilidades e esforços, no sentido de promover o desenvolvimento harmônico e a interação efetiva da organização. A dificuldade enfrentada pelas empresas em cumprir as exigências competitivas individualmente, faz com que estas atribuam à cooperação maior importância (BALESTRIN; VERSCHOORE, 2009). Portanto, na busca pela sobrevivência e competitividade, as MPEs têm adotado medidas estratégicas e se direcionado cada vez mais para as parcerias (VARRICHIO et al., 2012; AMATO NETO, 2008).

É percebido, então, vantagens atribuídas às empresas que se inserem em uma rede de cooperação, tais como: ganhos de escala e poder de mercado; condições para aprendizagem e inovação; redução de custos e riscos, entre outros (VERSCHOORE; BALESTRIN, 2008). Em um estudo realizado com MPEs na cidade de Maceió-AL, verificou-se que as redes têm sido responsáveis por fortalecer os pequenos mercados, bem como auxiliar no desenvolvimento local. Aliado a isto, observou-se que têm contribuído para a geração de empregos e a qualificação produtiva das empresas por meio da promoção de cursos e capacitações (SOUZA et al., 2014).

Em uma pesquisa elaborada através da análise dos programas europeus de desenvolvimento de clusters e redes de cooperação foi constatado que as MPEs europeias envolvidas em redes de cooperação têm demonstrado desempenho acima da média quando comparadas às demais empresas de seus respectivos setores, apresentando crescimento tanto em relação ao número de empresas quanto ao número de empregados (GEROLAMO et al., 2008).

Verifica-se, pois, vários estudos no que diz respeito aos benefícios de MPEs que se inserem em redes de cooperação (TONDOLO; SCHNEIDER, 2004; REIS et al., 2008; VERSCHOORE; BALESTRIN, 2008; TURETA; PAÇO-CUNHA, 2008; OLIVEIRA; CÂNDIDO, 2009; MAGALHÃES et al., 2009; OLIVEIRA et al., 2011; CASTRO; BULCAGOV; HOFFMANN, 2011). Todavia, não se verifica a presença de muitas pesquisas que atestem sobre o desempenho de MPEs participantes de uma rede de cooperação vis-à-vis 
aquelas não inseridas neste contexto. Neste ponto, Verschoore e Balestrin (2008), apresentam esta análise como sendo uma contribuição para o avanço no conhecimento da área.

Portanto, surgem questões como: a inserção de uma empresa em uma rede de cooperação apresenta benefícios superiores às empresas que não estão inseridas em uma rede de cooperação? Além disso, a forma de organização de empresas em redes de cooperação gera implicações para as relações sociais suscitando a troca de conhecimentos e podendo potencializar o capital humano do gestor. Sendo assim, é possível que as características dos gestores de empresas inseridas em redes de cooperação sejam superiores às características dos gestores das empresas não inseridas na rede? E, a partir disso: O nível de utilização de práticas de gestão entre os dois tipos de empresas difere?

A partir do exposto e das indagações apresentadas, obtém-se uma problemática de estudo que busca contribuir para o campo teórico. Adicionalmente, o confronto entre o desempenho organizacional apresentado por empresas inseridas em redes de cooperação versus empresas não inseridas em uma rede de cooperação abrirá a possibilidade de aprimorar os resultados da cooperação, amplificando as chances de perpetuá-las. Diante do exposto, propõe-se o seguinte problema de pesquisa:

No tocante às MPEs, a inserção em redes de cooperação horizontais conduz a um desempenho organizacional superior àquelas que atuam independente de qualquer relação interorganizacional?

\subsection{OBJETIVOS DO ESTUDO}

Considerando a problemática exposta, tem-se como objetivo principal deste estudo:

Verificar se as MPEs inseridas em redes de cooperação horizontais apresentam desempenho organizacional superior àquelas que atuam independente de qualquer relação interorganizacional.

Como objetivos específicos:

- Descrever o perfil das MPEs inseridas em redes horizontais de cooperação e das MPEs que atuam independente de qualquer relação interorganizacional e verificar se há diferença entre os respectivos perfis;

- Descrever o perfil dos entrevistados das MPEs inseridas em redes horizontais de cooperação e dos entrevistados das MPEs que atuam independente de qualquer relação interorganizacional e verificar se há diferença entre os respectivos perfis. 


\subsection{DELIMITAÇÕES DO ESTUDO}

Haja vista a importância que é definir o objeto de estudo faz-se necessário também expor as delimitações que evidenciem o que não se pretende estudar ou abordar. Por exemplo, não é objetivo desta pesquisa, propor um modelo de medição de desempenho das empresas. Entende-se também que há uma grande quantidade de variáveis que influenciam o desempenho organizacional das empresas. Ainda mais, por se tratar de uma pesquisa envolvendo redes de cooperação em que as relações são complexas e há a interdependência entre os participantes e mutualidade nas influências de cada participante. Porém, a presente pesquisa se propõe a investigar apenas as relações entre algumas variáveis e o desempenho das organizações.

Adicionado a isso, é relevante destacar que as relações interorganizacionais enquadradas no presente estudo são as redes horizontais de cooperação. Isto implica na exclusão de todo e qualquer outro tipo de relação interorganizacional existente, a exemplo de alianças estratégicas, clusters, joint venture ou redes verticais. Também estão exclusas da pesquisa as redes organizadas em formas de franquias ou rede de filiais. Tais delimitações permitem obter uma pesquisa mais direcionada aos objetivos do estudo.

\subsection{ESTRUTURA DO TRABALHO}

O presente estudo está estruturado em 5 capítulos, contando com este capítulo introdutório. O segundo capítulo, por sua vez, apresenta o referencial teórico e está subdividido em seis tópicos. No primeiro tópico são explanados aspectos relativos à cooperação interorganizacional, de modo que o leitor possa compreender a respeito da colaboração empresarial. Subsequente a isto, são delineados conceitos e tipologias de relações interorganizacionais, ressaltando as características das redes horizontais de cooperação que são o objeto de estudo desta pesquisa.

O terceiro tópico desse capítulo aborda conceitos mais aprofundados de redes horizontais de cooperação interorganizacional retratando as fases de formação das Redes de Cooperação Horizontais, bem como suas peculiaridades. Adicionado a isso, disserta a respeito dos benefícios obtidos pelas organizações, decorrentes de seu ingresso em uma Rede Horizontal de Cooperação. 
O quarto tópico do segundo capítulo discorre a respeito do desempenho organizacional, evidenciando as perspectivas de avaliação de desempenho e elucidando a relevância da medição de desempenho para as empresas. O quinto tópico, complementar ao quarto tópico, retrata os fatores que podem influenciar o desempenho organizacional e concomitante a isto suscita fundamentos que contribuem para complementação dos objetivos específicos do estudo. O sexto e último tópico do segundo capítulo elucida os achados das pesquisas desenvolvidas nos últimos anos acerca da temática de desempenho organizacional de redes de cooperação horizontais constituídas por MPEs, bem como evidencia aspectos a respeito de estudos que envolvem as redes de cooperação de um modo geral.

O terceiro capítulo trata dos métodos de pesquisa empregados, detalhando a amostra da pesquisa, os procedimentos de coleta e análise de dados. Subsequente a este, tem-se o quarto capítulo em que são transcritos os resultados da pesquisa empírica e análises dos dados coletados, além das discussões dos resultados. Por fim, o quinto capítulo denota as implicações do estudo para academia, as limitações e sugestões para pesquisas futuras, além de evidenciar as considerações finais da pesquisa. 


\section{CAPÍTULO II: REFERENCIAL TEÓRICO}

O presente capítulo apresenta a revisão da literatura deste estudo, abordando inicialmente aspectos relativos à cooperação interorganizacional, expondo conceitos e tipologias de relações interorganizacionais, ressaltando as características das redes horizontais de cooperação que são o objeto de estudo desta pesquisa.

Em seguida, conceitos associados às redes horizontais de cooperação interorganizacional são abordados, dissertando a respeito dos benefícios obtidos pelas organizações que optam ingressar em uma Rede Horizontal de Cooperação.

Além disso, discute-se a respeito do desempenho organizacional, evidenciando as perspectivas de avaliação de desempenho e elucidando a relevância da medição de desempenho para as empresas, bem como os fatores que podem influenciá-lo. Por último, são evidenciados os achados das pesquisas desenvolvidas nos últimos anos acerca da temática de desempenho organizacional de redes de cooperação horizontais.

\subsection{COOPERAÇÃO INTERORGANIZACIONAL}

O termo cooperar procede do latim, do verbo cooperari, como junção de cum e operari que significa o ato de produzir em conjunto, "trabalhar com", em que o cum, quer dizer "junto, com", ao passo que operari, expressa "trabalhar" (CAVALCANTI, 2006). Assim, como de acordo com Ferreira (2010), cooperar refere-se a "trabalhar em comum; colaborar", sabe-se que a cooperação consiste em um processo em que duas ou mais pessoas possuem um objetivo em comum e desejam unir forças para juntas angariar melhores resultados.

Colaboração, sinônimo de cooperação, consiste em um método por meio do qual, indivíduos distintos buscam trabalhar unidos em prol da resolução de problemas diversos, de forma que suas diferenças sejam exploradas (GRAY; WOOD, 1991). O que se pode destacar na definição de colaboração apresentada pelos autores é a forma como os problemas podem ser solucionados, tendo em vista que, haverá diversas visões a respeito do mesmo e consequentemente haverá também opiniões distintas sobre como solucioná-lo. Este ponto pode ser considerado como vantagem uma vez que, abre um leque de oportunidades na resolução de problemas, isso porque, segundo os autores consultados, todas as teorias organizacionais corroboram no que diz respeito às dificuldades enfrentadas por uma 
organização, a exemplo de complexidade ambiental, incerteza e turbulência, sendo a cooperação um fator contributivo na minimização de tais problemas.

Nas últimas três décadas, a cooperação interorganizacional, cujo objetivo está centrado na geração de soluções conjuntas, tem recebido destaque em pesquisas e práticas organizacionais (TEIXEIRA; VITCEL; BEBER, 2007; BALESTRIN et al., 2010). O tema tem sido amplamente difundido em muitos países, principalmente na Europa e nos Estados Unidos. Em nível nacional, o tema também tem despertado o interesse dos pesquisadores, apesar de os estudos estarem mais concentrados no Sul do país (BALESTRIN et al., 2010; CASTRO; BULGACOV; HOFFMANN, 2011).

Observa-se que o interesse pelo assunto é despertado na medida em que a empresa se expõe a ambientes competitivos, isto porque quando estas se firmam em relacionamentos interorganizacionais, tornam-se mais sólidas diante de incertezas ambientais. Somado a isso, contemplando o cenário excessivamente globalizado e competitivo, julga-se a cooperação como uma maneira de superar as incertezas e perdurar. De fato, a cooperação é considerada uma estratégia, entre tantas outras, que é capaz de encaminhar as empresas ao sucesso, sendo a formação dos acordos de cooperação um meio essencial para granjear objetivos estratégicos em longo prazo que as empresas não inseridas em um acordo cooperativo não podem obter (MERCHANT; SCHENDEL, 2000; BRASS et al., 2004; GHISI; MARTINELLI, 2005; FRANCO, 2007).

A cooperação instaura-se para cumprir com um objetivo comum entre os envolvidos e sucede-se quando indivíduos, defrontados com um problema, unem-se em prol da resolução das dificuldades enfrentadas, de modo que são atribuídas tarefas a cada um (TEIXEIRA et al., 2007). A partir disto, pode-se considerar que a conjuntura competitiva favorece a cooperação. Esta, por sua vez, é uma das estratégias encontradas pelas empresas para adequar-se ao ambiente caracterizado por constantes transformações. A finalidade é estabelecer uma meta entre os participantes da rede e construir ferramentas capazes de aplacar os problemas que certamente surgirão.

$\mathrm{O}$ entendimento de que a cooperação consiste em um sistema em que pessoas ou organizações, sejam essas formais ou informais, conectam-se em prol da realização de objetivos individuais ou coletivos, provém de longa data, assim como estudos que envolvem a cooperação entre empresas são desenvolvidos desde os primórdios da pesquisa científica (VERSCHOORE FILHO, 2006). Conforme descreve Grassi (2007), os acordos de cooperação entre firmas existem há séculos, porém, até os anos 80 , estes não eram considerados benéficos, visto que ao se falar em cooperação, acordos como os cartéis eram os 
mais citados. O cenário passa a mudar com o advento da globalização e consequente modificação de paradigma tecnológico. Dessa forma, "a cooperação apresenta-se mais pelo seu caráter "benévolo" de acordos visando à inovação" (GRASSI, 2007, p. 49).

Desde então, cada vez mais tem crescido o interesse em uma cooperação entre empresas, verificando-se uma "tendência para que continue a evoluir devido a fatores como a crescente competitividade internacional, a aceleração do progresso tecnológico e uma continuada sofisticação dos mercados, clientes e fornecedores à qual se tem vindo a assistir" (FRANCO, 2007, p. 150). Portanto, uma vez considerados todos os aspectos mencionados, obtém-se entendimento de que a utilização da cooperação como estratégia representa às empresas uma alternativa viável.

Combs e Ketchen (1999), afirmam que a cooperação interfirmas existe quando duas ou mais organizações agem reunidas para ir ao encalço de ganhos mútuos, sem, contudo, perder sua autonomia e independência. Wegner (2011, p. 26) corrobora ao afirmar que "a cooperação interorganizacional refere-se a todos os tipos de relações de caráter competitivo entre duas ou mais empresas, podendo resultar em uma série de arranjos cujo objetivo é tornar os participantes mais aptos a competir no mercado". Schermerhorn (1975, p. 847) complementa ao expor que "[...] a cooperação interorganizacional pode ser definida como a presença de relações deliberadas entre organizações autônomas para o conjunto alcance de objetivos individuais".

Do exposto, pode-se considerar quanto à cooperação, seja esta organizada a partir da união de indivíduos ou organizações, que há a necessidade de um objetivo claramente definido, isto porque sem uma meta estabelecida não há como projetar ações em conjunto.

Consoante à cooperação interorganizacional tal objetivo consiste em transformar os integrantes mais preparados para enfrentar a competição no mercado, conforme fora destacado por Koza e Lewin (2000) o sucesso em um acordo de cooperação é constatado quando este melhora a posição competitiva das empresas participantes dele. Além de uma maior preparação para enfrentar o mercado competitivo, são identificados outros objetivos almejados pelas organizações que adentram em cooperações, a exemplo de ampliação da eficiência, aprimoramento do conhecimento e aprendizagem, diminuição de custos, diminuição de riscos, entre outros (NIELSEN, 1988; WILDEMAN, 1998).

Estudos internacionais como os de Müller-Seitz (2011), Lee e Monge (2011), Sirmon et al. (2010), Atouba e Shumate (2010), Turrini et al. (2009), e nacionais como os de Poletto, Duarte e Mata (2011), Kunzler e Bulgacov (2011), Balestrin et al. (2010), reconhecem a 
relevância da cooperação interorganizacional na obtenção de resultados que não estão restritos apenas à união dos recursos organizacionais individuais.

No que diz respeito aos ganhos obtidos, Olson (1999) os denomina de benefícios coletivos exclusivos. Por pertencerem ao grupo são coletivos e pelo fato de se limitarem apenas aos participantes do grupo são considerados exclusivos. Portanto, a cooperação entre organizações representa a opção de obter vantagens que dificilmente seriam alcançadas sem sua contribuição. Este fato explica a relevância que as empresas e a comunidade acadêmica atribuem ao tema.

Grassi (2007) afirma ser a cooperação interorganizacional um assunto que se mostra cada vez mais relevante para a compreensão da atuação e do desempenho das organizações na atualidade. Sobretudo, se for considerado que a união de esforços representa uma estratégia elementar no anseio pela competitividade, num meio austero da concorrência e da globalização dos mercados. Reis et al. (2008, p. 21) corroboram ao afirmar que a importância da cooperação é realçada pela carência de criar novas possibilidades de "sobrevivência e vantagens competitivas por parte dos indivíduos e das organizações para obter competências e potencialidades complementares, por meio da inserção dos atores sociais em múltiplas redes de relações e interações".

Por exemplo, por meio da cooperação, as empresas têm a possibilidade de adentrar em novos mercados locais e externos, ter acesso a novos recursos, produtos e tecnologias além de aumentar a qualidade e outros meios de acrescentar valor aos seus produtos e/ou serviços (JOHNSON; HOUSTON, 2000; MERCHANT; SCHENDEL, 2000). De fato, conforme sugere a bibliografia, a cooperação entre organizações proporciona um melhor desempenho às empresas nela envolvidas (DUYSTERS; HANGEDOORN; LEMMENS, 2002; SÁNCHEZ; VALENTÍN, 2010).

No entanto, a cooperação interorganizacional não é uma ocorrência simples, pelo contrário, mostra-se muito labiríntica em razão de que as atividades cooperativas são instituídas sobre as atividades competitivas e as duas necessitam relacionar-se (FIALHO, 2005). Hardin (1995) estabelece três formas de interação entre as pessoas, são elas: conflito, coordenação e cooperação. No conflito, uma das partes alcançará ganhos quando a outra parte perder, na coordenação ocorre o contrário, uma das partes obterá resultados apenas se a outra também obtiver, ao passo que, a cooperação corresponde à união do conflito e coordenação.

Contudo, vale destacar que assim como são os bens públicos, são as conquistas alcançadas pela cooperação, certamente não serão gozadas apenas por um dos participantes (VERSCHOORE FILHO, 2006). Conforme complementa Olson (1999, p. 27), “o simples 
fato de uma meta ou propósito ser comum a um grupo significa que ninguém do grupo ficará excluído do proveito ou satisfação proporcionada por sua consecução". Ambos os autores concentram-se em destacar que os benefícios gerados pela cooperação são compartilhados a todos os participantes, ou seja, não há o favorecimento de um ou outro integrante em relação aos ganhos provenientes da relação cooperativa estabelecida.

Franco (2007) propôs um modelo, baseado nas abordagens teóricas mais referenciadas no estudo da cooperação empresarial, que identifica três fases que poderão fazer parte do processo da cooperação - formação, implementação e desenvolvimento. Resumidamente, no Quadro 2, apresenta-se a identificação dos principais aspectos que as caracterizam.

Quadro 2: Aspectos que caracterizam as três fases do processo de cooperação interorganizacional

\begin{tabular}{|c|l|}
\hline Fase & \multicolumn{1}{|c|}{ Caracterização } \\
\hline \multirow{5}{*}{ Formação } & $\begin{array}{l}\text { Fase onde a negociação, o compromisso, execuções e avaliações são os principais } \\
\text { componentes. Nesta, os envolvidos analisam em conjunto suas motivações, os possíveis } \\
\text { investimentos e verificam as incertezas do negócio que estão adentrando para ser } \\
\text { desenvolvido. Além disso, nessa fase serão identificados e selecionados os potenciais } \\
\text { parceiros, analisando o histórico da empresa e do empresário, sendo isto necessário para } \\
\text { minimizar as incertezas e estabelecer obrigações de modo que as conexões entre as } \\
\text { empresas sejam fortalecidas. }\end{array}$ \\
\hline \multirow{5}{*}{ Implementação } & $\begin{array}{l}\text { Esta fase é caracterizada pela identificação de possíveis obstáculos que deverão ser } \\
\text { discutidos se, por ventura, for constatado que os parceiros possuem interesses distintos } \\
\text { decorrentes de fatores internos e externos da empresa, tais como tecnologia, caráter } \\
\text { familiar, setor de atividade, cultura. Portanto, nessa fase haverá o alinhamento das } \\
\text { características e objetivos da cooperação. }\end{array}$ \\
\hline Desenvolvimento \\
$\begin{array}{l}\text { Os componentes importantes dessa fase são desenvolvimento, o sucesso, a estabilidade e } \\
\text { os resultados da colaboração entre empresas. Pode-se considerar que esta é a fase em que } \\
\text { são observados os frutos obtidos decorrentes do acordo cooperativo. }\end{array}$ \\
\hline
\end{tabular}

Fonte: Elaborado pela autora, baseado na pesquisa de Franco (2007)

Apesar do modelo proposto, um processo de cooperação interorganizacional não necessariamente passará pelas três fases elencadas. Adicionado a isso, cada processo possui particularidades e pode apresentar problemas específicos em cada fase que, serão solucionados com base em seus objetivos e interesses, que no caso de não coincidirem com o de ambas as partes pode levar à dissolução (FRANCO, 2007).

Muitos são os acordos de cooperação, os achados teóricos têm citado fusões, aquisições, alianças estratégicas, formação de redes e parcerias, como relações interorganizacionais (CUNHA, 2002), além de joint ventures, programação conjunta, colaborações, grupos empresariais, consórcios, contratos relacionais, e algumas formas de franchising e outsourcing como exemplos de cooperação interorganizacional (PODOLNY; PAGE, 1998). Dentre esses, observa-se que as alianças estratégicas e redes horizontais, sob a 
forma de redes de cooperação, são as condições de cooperação mais comuns (TEIXEIRA et al., 2007).

À medida que parcerias e alianças são adotadas como estratégias pelas grandes organizações (BALBINOT; MARQUES, 2009), acordos de colaboração, a exemplo de redes de cooperação são implantadas nas MPEs, objetivando a solução de adversidades partilhadas (ANDRADE; HOFFMANN, 2010; CASTRO; BULGACOV; HOFFMANN, 2011; MAGALHÃES; DAUDT; PHONLOR, 2009).

Devido às diversas abordagens teóricas observadas a respeito do tema, observou-se que há inúmeras tipologias de relações interorganizacionais, discussão esta que será abordada no tópico seguinte.

\subsection{TIPOLOGIAS DE RELAÇÕES INTERORGANIZACIONAIS}

As relações interorganizacionais são consideradas uma forma organizacional contemporânea, apesar de que desde a existência da humanidade, indivíduos e entidades cultivam continuamente as inter-relações (BALESTRIN; VARGAS; FAYARD, 2008). Estas podem ser conceituadas como sendo o acordo, relativamente perdurável, que ocorre entre duas ou mais empresas que estabelecem entre si transações, fluxos e ligações de recursos (FROEHLICH, 2013; OLIVER, 1990).

As referidas relações propiciam soluções para o desenvolvimento das organizações e aumentam suas chances de sobrevivência quando inseridas em ambientes competitivos (SILVA; SCHROEDER; HOFFMANN, 2005), ou seja, são reconhecidas como uma estratégia empresarial que culminará em vantagens às empresas participantes, "unindo forças entre duas ou mais delas, por meio de confiança mútua e o desenvolvimento conjunto de projetos variados" (TAVARES; CASTRO, 2012, p. 33).

Sabe-se que há conexão entre as empresas quando há um relacionamento que afeta ou é afetado pelo que acontece em outros relacionamentos. As relações interorganizacionais configuram-se como um sistema interligado de atores e relacionamentos, em que muito provavelmente não possuirá apenas um ator como dominante, ou seja, atuará de forma descentralizada e sem limites constituídos (ATOUBA; SHUMATE, 2010; LEE; MONGE, 2011).

Há uma vasta diversidade de tipologias de relações interorganizacionais e por este motivo, o referido termo tem sido cercado por certa ambiguidade. Pode-se observar que estas 
surgem sob diferentes enfoques, diferentes conjunturas e variadas manifestações culturais (BALESTRIN; VARGAS, 2004; AGUIAR et al., 2014).

Por esse motivo, as relações interorganizacionais podem assumir diversas formas, como parcerias, aquisições, fusões, consórcios, joint ventures, redes de cooperação, distritos industriais, clusters, organizações em redes, redes intrapessoais, redes intraorganizacionais, redes sociais, redes de governo, teias, blocos de relacionamentos estratégicos, alianças, organizações sem fronteiras, arranjos híbridos, distritos industriais, networks etc. O ponto de interseção entre todos os tipos de relacionamentos é a união de duas ou mais organizações dispostas a trabalharem juntas almejando vantagem competitiva (BRIDGEWATER; EGAN, 2002).

Tais tipologias são provenientes dos modelos genéricos de relações interorganizacionais. Alguns dos modelos que se destacam como exemplos tipológicos de redes interorganizacionais no domínio das relações entre as organizações são o de Miles e Snow (1986) e o modelo de Håkansson (1987) (CÂNDIDO; ABREU, 2000; BRONZO; HONÓRIO, 2003). O primeiro admite que as organizações estabeleçam entre si uma relação de interdependência e inter-relacionamento, em que há uma empresa central instituindo um elo entre a dinâmica gama de relacionamentos, sendo denominada de corretores (agenciadores). De acordo com os autores do modelo, quando as empresas passam a atuar na forma de relações interorganizacionais, há o desenvolvimento de novos pontos de vista para as variadas funções e processos organizacionais.

No que diz respeito ao segundo modelo exposto, considera-se este mais completo quando comparado ao modelo de Miles e Snow (1986), visto que Håkansson parte do pressuposto que uma relação interorganizacional diz respeito ao relacionamento em longo prazo entre duas ou mais empresas almejando a competitividade em cenários econômicos cada vez mais turbulentos através da dinamização dos processos organizacionais.

Outro modelo que busca fornecer melhor entendimento sobre a tipologia de relações interorganizacionais, em meio à vasta diversidade, corresponde ao modelo de Marcon \& Moinet (BALESTRIM; VARGAS, 2004; BALESTRIM; VARGAS; FAYARD, 2005, VERSCHOORE FILHO, 2006; WEGNER, 2011). Este, por sua vez, em uma tentativa de apresentar melhor compreensão acerca da heterogeneidade de tipologias de relações interorganizacionais, foi criado por Marcon e Moinet um gráfico denominado de mapa de orientação conceitual (Figura 1). O referido mapa apresenta quatro quadrantes que propõe a identificação das principais dimensões em que as redes são estruturadas (BALESTRIN; VARGAS, 2004; BALESTRIN, 2005; ZEN; WEGNER, 2008). 


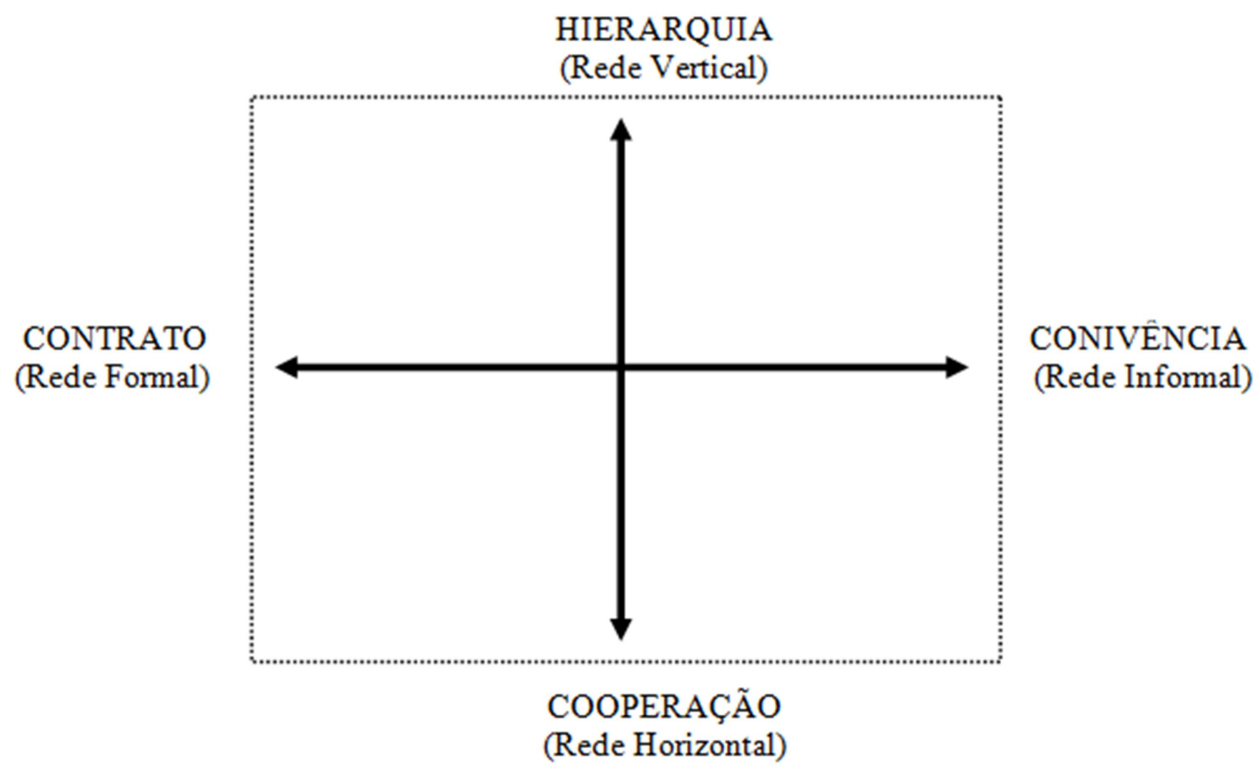

Figura 1: Mapa de Orientação Conceitual

Fonte: Balestrin e Vargas (2004, p. 207)

De acordo com o Mapa de Orientação Conceitual (Figura 1), pode-se observar que há a classificação da "cooperação interorganizacional em relações horizontais ou verticais entre os atores e pelo grau de formalização do arranjo" (WEGNER, 2011, p. 26). Balestrin e Vargas (2004) elucidam que o eixo vertical é constituído por um elo gerencial entre os atores da rede, de modo que tais relações interorganizacionais podem ser do tipo de uma rede vertical, a exemplo de uma rede do tipo matriz/filial, bem como uma rede horizontal, a exemplo de uma rede cooperação entre as MPEs. Ao passo que, o eixo horizontal, reproduz o grau de formalização determinado entre os atores, podendo ser informal como, por exemplo, relações de amizade, ou formal, quando se trata de contratos entre os envolvidos, no caso de contratos jurídicos, conforme se dá na formação de joint-ventures.

Entendendo que há diversidade de tipologias de relações interorganizacionais, é importante ressaltar que em cada um dos pontos do quadrante, poderá ser identificado um tipo de relação interorganizacional (BALESTRIN; VARGAS, 2004; WEGNER, 2011). No Quadro 3 é possível identificar os supracitados tipos de relação interorganizacional descritos resumidamente. 
Quadro 3: Descrição dos tipos de relação interorganizacional desenvolvidos a partir do Mapa de Orientação Conceitual de Marcon e Moinet

\begin{tabular}{|c|c|c|}
\hline Eixo do Mapa & Tipo de Rede & Descrição \\
\hline \multirow[b]{2}{*}{ Vertical } & $\begin{array}{l}\text { Redes } \\
\text { Verticais }\end{array}$ & $\begin{array}{l}\text { Atua nos elos de cadeia produtiva de um determinado produto que são } \\
\text { distintos, de forma que se constitui no meio de empresas que atuam em } \\
\text { níveis distintos. }\end{array}$ \\
\hline & $\begin{array}{c}\text { Redes } \\
\text { Horizontais }\end{array}$ & $\begin{array}{l}\text { Consiste naquelas que conectam empresas da mesma indústria, ou seja, } \\
\text { que competem no mesmo mercado e sucede-se entre organizações de } \\
\text { mesmo estágio no processo produtivo. As empresas preservam sua } \\
\text { independência individual, porém optam por empregar algumas das } \\
\text { referidas atividades conjuntas. }\end{array}$ \\
\hline \multirow{2}{*}{ Horizontal } & Redes Formais & $\begin{array}{l}\text { São aquelas formalizadas através de acordos contratuais, em que são } \\
\text { determinadas normas de conduta entre os atores, como por exemplo, as } \\
\text { alianças estratégicas, as joint-ventures e as franquias. }\end{array}$ \\
\hline & $\begin{array}{l}\text { Redes } \\
\text { Informais }\end{array}$ & $\begin{array}{l}\text { Diz respeito aos encontros de conivência, ditos como informais entre os } \\
\text { atores, sem o firmamento de nenhum contrato formal que constitua } \\
\text { regulamentos, de maneira que as ações são baseadas na confiança mútua. }\end{array}$ \\
\hline
\end{tabular}

Fonte: Elaborado pela autora, baseado em Silverman e Baum, 2002; Balestrin e Vargas, 2004; Mesquita e Lazzarini, 2008; Zen e Wegner, 2008

Observa-se que no eixo vertical estão as redes verticais e as redes horizontais, ao passo que o eixo horizontal é constituído pelas redes formais e informais. É válido destacar que uma organização pode estar inserida em uma rede horizontal e ao mesmo tempo ter outras relações em redes verticais (MESQUITA; LAZZARINI, 2008; CUNHA et al., 2011). Além disso, raramente encontra-se uma rede que possua estrutura idêntica à outra, sendo assim, tal classificação proposta por Marcon e Moinet considera-se válida, pois tenta resumir e englobar todas as possíveis relações interorganizacionais.

Por último, compreende-se que as tentativas de criar modelos tipológicos auxiliam na construção do campo de estudo das relações interorganizacionais. Os modelos de Miles e Snow (1986) e Håkansson (1987), por exemplo, propiciam a disposição das competências particulares demandadas para o relacionamento de permuta e interação entre os atores da relação interorganizacional. O modelo de Marcon e Moinet, por sua vez, destaca-se pela tentativa de condensar as possíveis tipologias de relações interorganizacionais caracterizandoas pelas relações verticais ou horizontais, sendo esta a classificação que serve para os objetivos deste trabalho.

No entanto, ainda que as pesquisas a respeito das relações interorganizacionais, que buscam compreender a maneira como estas atuam e como estão estruturadas, tenham evoluído ao longo do tempo (GRANDORI; SODA, 1995; PODOLNY; PAGE, 1998; PROVAN; FISH; SYDOW, 2007), juntamente com estudos que procuram reproduzir algumas tipologias (WHETTEN, 1981; GRANDORI; SODA, 1995; BORGATTI; FOSTER, 2003; TODEVA; 
KNOKE, 2005; PRENKERT; HALLÉN, 2006), problemas ainda persistem tais como a ausência de um conceito padrão, teoria e metodologia da área. De acordo com Cunha, Luiz Passador e Souza Passador (2011, p. 3), "as definições conceituais ainda são confundidas, quando não misturadas, e teorias aplicáveis a diferentes contextos industriais são transpostas ao contexto das redes interorganizacionais sem a devida adaptação”. É, portanto, notória a heterogeneidade e interdisciplinaridade do estudo das redes interorganizacionais, devido as suas múltiplas abordagens (OLIVEIRA; REZENDE; CARVALHO, 2011).

No que diz respeito às tipologias apresentadas, entende-se que a mais adequada para o presente estudo é a classificação como redes horizontais, uma vez que, “o caráter horizontal deve-se à inexistência de uma organização líder ou coordenadora, com os participantes interagindo em igualdade de condições" (WEGNER, 2011, p. 28). Aspecto esse que caracteriza as organizações que são a razão do presente estudo. Isto porque existem características nas Redes Horizontais que as diferem dos outros arranjos elencados, posicionando essa tipologia de relação interorganizacional como alvo da presente pesquisa. Algumas dessas características são: a) constituída por MPEs; b) proximidade geográfica entre as empresas; c) as organizações participantes atuam em um mesmo segmento de mercado; d) relação em que a confiança torna-se elemento chave, uma vez que, consiste em uma relação horizontal e cooperativa; e) duração de existência é de tempo indeterminado; e f) são estabelecidas ferramentas contratuais mínimas, apenas para o controle das normas básicas de governança (BALESTRIN; VARGAS, 2003).

Portanto, no transcorrer do presente estudo, a discussão será direcionada à tipologia de redes de MPEs, que: a) são geograficamente próximas; b) atuam em um mesmo segmento, c) desenvolvem inter-relações diretas com outros atores para metas exclusivas de negócios (HUMAN; PROVAN, 1997). Outros aspectos a respeito das redes de cooperação, em especial as redes horizontais são discutidas no tópico seguinte.

\subsection{REDES HORIZONTAIS DE COOPERAÇÃO INTERORGANIZACIONAL}

A forma final das relações interorganizacionais é uma rede (WHETTEN, 1981). A palavra "rede" é proveniente do latim (retis) e seu significado reporta-se a fios entrelaçados que constituem um tecido. O referido termo expandiu-se na área da administração de empresa e nos anos 30 alicerçou-se em diversas outras áreas do conhecimento. Sendo assim, o termo pode ser utilizado para uma infinidade de Ciências, incluindo não só teoria da organização, 
mas também neuro-ciências, pesquisa operacional, teoria da comunicação, entre outras (GHISI; MARTINELLI, 2005).

Em virtude da sua popularização, o significado do termo perdeu a essência, uma vez que, diferentes conceitos passaram a ser defendidos por diversos autores. Dessa forma, o termo assumiu variados aspectos, elementos de análise e métodos de pesquisa, ainda entre os estudiosos de um mesmo campo de atuação (GHISI; MARTINELLI, 2005).

No entanto, o presente estudo reporta-se a redes como forma de organização de atividades econômicas por meio da cooperação e coordenação entre empresas. Neste sentido, redes se encontram no cerne da teoria da organização, sendo utilizado, para fins desta pesquisa, para caracterizar a ligação de organizações que se conectam por algum motivo em comum, sendo a sua capacidade de obter resultados, diretamente proporcional ao número de conexões estabelecidas, ou seja, quanto maior o número de elos formados, maiores as chances de gerar bons resultados (FOMBRUN, 1982; GRANDORI; SODA, 1995; REIS et al., 2008; SCHLITHLER, 2010).

O surgimento das redes se deu a partir dos anos 1980, período em que foi necessária a adoção de medidas estratégicas, por parte das empresas, de modo a suportar as exigências competitivas sinalizadas na virada do século (MILES; SNOW, 1986). De acordo com Lazzarini (2007, 2008), acordos interorganizacionais e redes de cooperação tornaram-se uma ferramenta estratégica para auxiliar empresas que encaram concorrência desleal.

Isto porque a rede é composta por todas as interações entre as organizações em uma população, independentemente de como essa se organiza, em duplas, conjuntos de organização, ou conjuntos de ações (WHETTEN, 1981). Constituem-se com o objetivo de agregar qualidades de todas as empresas envolvidas, de maneira que isto propicie ganhos de escala de união e inserção ao ambiente competitivo, o que se mostra benéfico às MPEs, uma vez que, estas possuem dificuldades de sobrevivência frente aos ambientes competitivos (TURETA; PAÇO-CUNHA, 2008).

Verschoore Filho (2006) corrobora ao afirmar que o principal objetivo da rede de cooperação é concentrar qualidades organizacionais que propiciem às empresas participantes desta ajustar-se ao ambiente competitivo, amparadas por medidas padronizadas, no entanto descentralizadas, de forma que os resultados de escala em união sejam atingidos. O mesmo autor a conceitua como uma 
organização composta por um grupo de empresas com objetivos comuns, formalmente relacionadas, com prazo ilimitado de existência, de escopo múltiplo de atuação, na qual cada membro mantém sua individualidade legal, participa diretamente das decisões e divide simetricamente com os demais os benefícios e ganhos alcançados pelos esforços coletivos (VERSCHOORE FILHO, 2006, p. 60).

O fato de uma rede de cooperação ser um grupo composto por mais de uma empresa, a coloca em posição vantajosa. Isto porque, ao atuar individualmente, a organização enfrenta dificuldades ao deparar-se com os desafios do meio empresarial, devido à extensa gama de exigências competitivas, a exemplo do aprendizado contínuo e inovação (CASTELLS; CARDOSO, 2005). Além disso, sabe-se que as "organizações não contemplam todos os recursos e competências necessárias a uma oferta compatível com a demanda, sendo esse um dos fatores que reforçam a necessidade de que suas ações de complementaridade sejam articuladas em redes" (REIS et al., 2008, p. 23).

Um fator primordial que deve prevalecer na constituição de uma rede de cooperação é que os interesses coletivos devem sobressair-se aos individuais, eliminando-se elementos oportunísticos (LOURENZANI et al., 2006). Adicionado a isso, a rede objetiva fornecer a todos os seus participantes, de forma igualitária, oportunidades de aprendizagem e acesso a recursos, impedindo uma possível assimetria de benefícios e desempenho (WEGNER; MAEHLER, 2012).

Isto é proporcionado através de um relacionamento mutuamente favorável, mediado pela confiança entre os integrantes (CHILD; MACGRATH, 2001). Ou seja, "não existe uma empresa líder, que tenha autoridade para impor regras. Além disso, as empresas participantes permanecem legalmente independentes, mas desenvolvem atividades conjuntamente, com o objetivo de ampliar sua competitividade" (WEGNER; CALLADO; AGNES, 2014, p. 2).

Verschoore Filho (2006) destaca que as relações estabelecidas entre as empresas participantes constituem o enfrentamento dos problemas, comuns a mais de uma empresa, e conduz às soluções em grupo, através das experiências individuais de cada membro, bem como daquelas advindas da própria inserção em uma rede. Tal conexão entre os participantes e a troca de informações entre si, fortalece reciprocamente os envolvidos. Aliado a isso, promove a diminuição do tempo e espaço nas inter-relações entre os participantes, elementos cruciais de estratégia no mercado competitivo do século XXI (FAYARD, 2000).

Verifica-se, portanto, que a rede de cooperação é uma alternativa viável para as organizações, tendo em vista ser o seu principal propósito agregar qualidades organizacionais que proporcione à empresa um ambiente adequado à competição sem, contudo prejudicar sua individualidade. 
A forma como as redes de cooperação são organizadas propicia um ambiente favorável à solução de problemas, troca de informação e conhecimento, dinamização dos processos, interação entre os participantes da rede, de modo que os mesmos podem compartilhar entre si suas experiências, ideias e estratégias novas para alavancar os negócios, constituindo uma alternativa relevante para os negócios.

Para fins desta pesquisa, entende-se que as redes de cooperação podem ser consideradas como estruturas horizontais provenientes de relacionamentos interorganizacionais coletivos (ZANCAN et al., 2010). Ademais, são organizações complexas, de modo que seu desenvolvimento está atrelado ao diálogo entre seus participantes, bem como do consenso entre os objetivos estabelecidos entre todos os envolvidos (CICCHETTI, 2003).

Tal conceito revela que as redes de cooperação podem, através do gerenciamento dos seus recursos compartilhados, vencer obstáculos no seu processo de formação. Isto porque, o desenvolvimento da rede ocorre de forma satisfatória na medida em que é reunido um conjunto de fatores favoráveis, advindos do contexto externo e interno. Com isso, será possível obter o entendimento para "gerenciar sua dinâmica de configuração, criando uma ambiência capaz de fazer as estruturas das redes consolidarem e prosperarem" (ZANCAN et al., 2010, p. 651).

O processo de formação de uma rede de cooperação envolve algumas fases e não ocorre de uma única maneira em todos os casos, ou seja, não pode ser considerado homogêneo (ZANCAN et al., 2010). Muitos são os estudos que discorrem acerca das fases evolutivas das redes de cooperação (LARSON, 1992; RING; VAN DE VEN, 1994; FRANCO, 2007).

O modelo de clico de vida das redes de cooperação que mais se enquadra na perspectiva do presente estudo é modelo adotado por Franco (2007), além de ser, também, o modelo mais recente entre as pesquisas citadas. Franco (2007), por sua vez, considera que no decorrer de sua constituição, a rede de cooperação sucede-se em três fases distintas, a saber: formação, consolidação e desenvolvimento, cada qual com suas particularidades.

A fase de formação, por exemplo, é caracterizada pelas discussões e tem como principais elementos a negociação, o compromisso, as execuções e as avaliações. Nesta primeira fase é avaliado o histórico da empresa e do empresário na tentativa de minimizar as incertezas, estabelecendo obrigações e expectativas entre os atores da rede (LARSON, 1992; RING; VAN DE VEN, 1994; FRANCO, 2007; ZANCAN, 2010). A formação consiste na fase em que se revelam as oportunidades de cooperação e em que são realizadas as 
negociações entre os atores da rede. Ademais, são traçados os objetivos coletivos e discutidos eventuais aspectos que necessitam ser ponderados para prevenção de possíveis adversidades que poderão surgir entre as partes envolvidas.

No que diz respeito à fase da consolidação ou implementação, nesta são definidas as características e metas da cooperação, bem como são definidos os métodos disponíveis para o acordo (FRANCO, 2007; ZANCAN et al., 2010). É nesta fase que possivelmente obstáculos irão despontar, decorrentes de interesses opostos entre os atores da rede de cooperação. Isto porque, fatores internos, a exemplo de dimensão, antiguidade, estratégia, caráter familiar, tecnologia etc., bem como fatores externos, tais como, cultura, setor de atividade, mercado, concorrência etc., podem causar divergências a respeito das decisões que serão tomadas (FRANCO, 2007; ZANCAN et al., 2010). Dessa forma, antes de implementar de fato, o acordo de cooperação entre as empresas, devem ser debatidos alguns desses possíveis obstáculos a fim de definir um consenso entre os atores.

E por fim, na fase do desenvolvimento, são observados elementos relevantes entre as empresas, são eles: o sucesso, a estabilidade e os resultados da colaboração. De modo que se o sucesso e a estabilidade forem atingidos, numa rede de cooperação, os atores terão sua competitividade realçada e consequentemente, apresentarão melhor desempenho, o que acarreta na melhoria da sua satisfação e processo de aprendizagem (FRANCO, 2007; ZANCAN et al., 2010). A medição do sucesso, por sua vez, está associada a diferentes fatores, elencados por diferentes estudiosos. Baird et al., (1990) afirmam que o alcance do sucesso de uma empresa na rede de cooperação ocorre quando esta é capaz de prosperar por meio do relacionamento, bem como pela viabilidade do acordo estabelecido, ou seja, o êxito da cooperação é decorrente do seu próprio resultado ou duração.

Aliado a isso, sabe-se que as MPEs que constituem as redes de cooperação possuem características em comum, que as destacam das demais organizações, características estas que são delineadas no tópico seguinte.

\section{Características de Redes Horizontais de Cooperação}

Entende-se que no contexto interorganizacional brasileiro, as redes de cooperação horizontais são apontadas como alternativa estratégica para sobrevivência organizacional, principalmente no que diz respeito à MPEs, que possuem maiores dificuldades de agir isoladamente (KLEIN; PEREIRA; QUATRIN, 2014). Comumente, as redes horizontais constituem-se de empresas concorrentes em busca de competitividade, conforme já fora 
mencionado no presente trabalho, alvejando a obtenção de benefícios, a exemplo do conhecimento mútuo, melhorias financeiras, inovação, informações diversificadas, potencialização das competências (LIN; YANG; ARYA, 2009; ALVES; BALSAN; BAZZO, 2010).

Balestrin e Vargas (2003, p. 3), elencaram, resumidamente, algumas das características comuns encontradas em redes de cooperação horizontais constituídas por MPEs. São elas, a saber:

a) formada por um grupo de MPEs; b) as MPEs situam-se geograficamente próximas; c) as MPEs operam em um segmento específico de mercado; d) as relações entre as MPEs são horizontais e cooperativas, prevalecendo mútua confiança; e) a rede é formada por um indeterminado período de tempo; e g) a coordenação da rede é exercida a partir de mínimos instrumentos contratuais que garantam regras básicas de governança.

É valido salientar que pelo fato das redes de cooperação serem horizontais, não há nenhuma empresa que seja a líder da rede, ao contrário, todas desfrutam igualmente dos benefícios da mesma e ao mesmo tempo têm igual participação no processo de tomada de decisões, sem abrir mão da sua individualidade e independência (CHAO, 2011). No entanto, Pereira, Venturini e Visentini (2006) destacam que apesar de empresas participantes da rede manter sua independência, estas não podem ser consideradas totalmente autônomas, tendo em vista que são interdependentes e estando nessas condições necessitam negociar para alcançar soluções conjuntas.

De fato, a união das empresas pode reduzir as incertezas do ambiente, fornecer recursos das empresas parceiras em redes e ser "uma importante fonte de geração de valor" (CORSTEN; GRUEN; PEYINGAUS, 2011, p. 550). É por intermédio da cooperação que as empresas granjeiam vantagens. No tópico seguinte, são explanados os benefícios decorrentes da associação em uma cooperação.

\section{Benefícios das organizações participantes de Redes Horizontais de Cooperação}

A permanência de uma empresa em uma rede de cooperação está associada aos benefícios gerados pela mesma, a partir da sua participação na referida rede, ou seja, só há fundamento aplicar tempo e recursos nesse tipo de atividade desde que "apresente uma relação custo-benefício positiva ou potencialmente positiva" (WEGNER; MAEHLER, 2012, p. 192). 
As redes contribuem para o êxito organizacional, de acordo com a maneira em que estão estruturadas, bem como pela sua capacidade de colaboração. Desta forma, verifica-se que os ganhos obtidos por empresas participantes de redes de cooperação são lógicos (PRAHALAD; RAMASWAMY, 2004; BALESTRIN et al., 2010). Adicionado a isso, a interação entre as empresas participantes fortalece em uma relação de reciprocidade, tendo em vista que estas permutam informações e experiências entre si.

Inúmeras pesquisas nacionais e internacionais (PODOLNY; PAGE, 1998; AMATO NETO, 2000; GULATI; NOHRIA; ZAHEER, 2000; BRASS et al., 2004; PACAGNAN, 2006; WEGNER; WITTMANN; DOTTO, 2006; VERSCHOORE; BALESTRIN, 2008; BALESTRIN; VARGAS; FAYARD, 2008; TURETA; PAÇO-CUNHA, 2008; OLIVEIRA; CÂNDIDO, 2009; SERRA; FERREIRA, 2010; FROEHLICH, 2013) analisaram os benefícios granjeados pelas empresas inseridas em uma rede de cooperação, como, por exemplo, adquirir habilidades e conhecimentos (através das experiências compartilhadas entre si e também das participações conjuntas em congressos, feiras e exposições), melhorias nas áreas de gestão financeira e estratégica, ganhos consistentes e duradouros a partir da autenticidade assumida através de uma única identidade para todos os associados. Isto porque as empresas obtém maior visibilidade junto ao seu público através de uma única logomarca desenvolvida para a rede.

Concernente a isso, é possível barganhar preço nas compras de produtos e serviços, tendo em vista que o aumento do volume das compras pode ocasionar na redução de valores dos produtos, minimizando assim, os custos destes, além de possibilitar às empresas oferecer uma maior diversificação nas linhas de produtos. Similarmente, tem-se como vantagens a partilha de ônus alusivos à realização de pesquisas ou desenvolvimentos e a divisão de custos e riscos referentes à exploração de novos mercados. Em alguns casos, também há maior facilidade para organizar treinamentos, assessoria jurídica e contábil compartilhada e suporte de marketing centralizado.

Verschoore e Balestrin (2008) resumem, portanto, em cinco tópicos, os benefícios de uma organização que se associam a uma rede: a) Ganhos de escala e poder de mercado; b) Acesso a soluções para as dificuldades das empresas; c) Condições para aprendizagem e inovação; d) Redução de custos e riscos; e e) Geração e manutenção de relações sociais.

No que diz respeito ao primeiro benefício, ganhos de escala e poder de mercado obtido, tem-se que, na medida em que há união de mais de uma empresa, há ampliação do poder individual, ou seja, em maior número as empresas podem obter maior poder de barganha com seus parceiros e fornecedores, além de ter mais chances de estabelecer sua 
marca na medida em que esta será mais exposta (LORENZONI; BADEN-FULLER, 1995; CAMPBELL; GOOLD, 2000; SERRA; FERREIRA, 2010).

Para as MPEs, que possuem como principais obstáculos enfrentados o baixo volume de compras, que impede a obtenção de melhores preços na aquisição de matérias-primas, a associação em uma rede de cooperação implicaria em um novo quadro de competição, em que possivelmente se colocaria em melhor posição frente aos concorrentes (TURETA; PAÇOCUNHA, 2008).

Ao retratar aspectos relativos ao acesso às soluções para as dificuldades das empresas refere-se ao fato de que a rede na qual a empresa está inserida pode auxiliar no desenvolvimento de soluções para dificuldades enfrentadas. A despeito disto, tem-se que nas MPEs os custos de participação em feiras, campanhas publicitárias, custos de treinamento e desenvolvimento de pessoas são mais onerosos e o acesso a atualização tecnológica e linhas de crédito e financiamentos se faz mais dificultoso, de forma que a associação em uma rede de cooperação minimizaria tais custos e poderia possibilitar um maior acesso a soluções de tecnologia e financiamento (TURETA; PAÇO-CUNHA, 2008).

A associação em redes propicia condições para aprendizagem e inovação, na medida em que há troca de "ideias e de experiências entre os associados e as ações de cunho inovador, desenvolvidas em conjunto pelos participantes" (BALESTRIN; VERSCHOORE, 2008, p. 1048-1049). Um dos principais elementos motivadores da cooperação em rede consiste na redução de custos e riscos (PRAHALAD; RAMASWAMY, 2004), neste está centrado o quarto benefício elencando. Em pesquisa realizada por Pereira (2004), em uma rede de material de construção, foi identificado, por exemplo, que após a associação das empresas em rede, houve diminuição em custos, a exemplo de: material de expediente, telefone, ações de marketing e criação da marca.

A inserção destas vantagens no contexto das MPE's pode representar um passo significativo para competir eficazmente perante as grandes organizações (BALESTRIN; VARGAS, 2003). De modo que, os inúmeros benefícios percebidos por organizações inseridas em redes impactam positivamente na expectativa de sobrevivência e no desempenho das MPEs (BRASS et al., 2004).

Portanto, a partir do exposto, entende-se que as empresas participantes de redes de cooperação possuem aproximação com recursos preciosos e até então inexplorados, a partir da constante evolução e permuta de conhecimentos que se sucede na referida rede. Por conseguinte, novas possibilidades são vivenciadas, propiciando uma fonte de vantagem competitiva sustentável. 


\subsection{DESEMPENHO ORGANIZACIONAL}

A presente seção se propõe a evidenciar as perspectivas de avaliação de desempenho, bem como elucidar a relevância da medição deste para que as empresas avaliem a efetividade de suas estratégias implementadas.

Sabe-se que com o advento da globalização e consequente aumento da competitividade entre as empresas, identifica-se uma procura maior acerca de resultados por parte destas, o que acarreta na necessidade de analisar os resultados auferidos, ou seja, de identificar o desempenho da organização. A avaliação de desempenho oferece a possibilidade de monitorar uma estratégia estabelecida pela organização, equiparando seu resultado com os objetivos definidos. Sendo assim, pode ser considerada como um procedimento de mensuração da efetividade das ações empresariais (NEELY; GREGORY; PLATTS, 1995; GONÇALVES; CUNHA; NEVES JÚNIOR, 2011).

Boffi et al. (2010) corroboram ao alegar que a avaliação de desempenho proporciona a análise dos resultados das empresas, podendo ser utilizada como complemento na gestão, uma vez que, propicia aos administradores conhecimento que resultam na aprendizagem organizacional. Para Igarashi et al. (2008), as organizações têm a possibilidade de avaliar sua capacidade de sobrevivência e continuidade por meio da análise do desempenho. Verifica-se que os autores se complementam e cada afirmação reforça a ideia de que a mensuração do desempenho organizacional fornece conhecimento ao gestor de como sua empresa está posicionada.

Portanto, o processo de conhecimento do desempenho é importante em qualquer negócio para o controle gerencial (OLSON; SLATER, 2002). Além disso, tem-se constatado o interesse crescente pelas medidas de desempenho organizacional em decorrência das alterações ocorridas no ambiente empresarial, bem como nas estratégias adotadas (McADAM; BAILIE, 2002).

Tendo em vista o aumento da competitividade nos negócios, a medição do desempenho organizacional propicia aos gestores visualizar o cenário em que seu empreendimento está enquadrado. Adicionalmente, também permite contemplar medidas que podem ser implementadas para aperfeiçoar o referido desempenho, ou seja, a medição deste também corresponde a uma ferramenta a ser acrescentada na busca por diferenciais competitivos.

Porém, avaliar o desempenho das organizações não constitui uma tarefa simples, pois se faz necessário possuir o conhecimento daquilo que será mensurado para que seja possível 
determinar quais medidas serão utilizadas em busca de alcançar o que se deseja (MACHADO; MACHADO; HOLANDA, 2007). Gunasekaran e Kobu (2007) julgam, por exemplo, atividade de encontrar medidas apropriadas de mensuração um grande desafio para os administradores.

Por ser um tema de relevância, que desperta a atenção dos pesquisadores em estudos conceituais ou empíricos (CARNEIRO et al., 2005), "ainda não há um consenso sobre como caracterizar o construto desempenho e sobre como mensurá-lo" (CARNEIRO et al., 2005, p. 1). Entretanto, comumente são apontados dois pontos de vista sobre o qual o desempenho pode ser mensurado: o primeiro refere-se ao aspecto subjetivo, em que o desempenho das organizações é medido de acordo com sua própria expectativa ou em relação ao seu concorrente mais próximo (PELHAM; WILSON, 1996), ao passo que, a segunda forma diz respeito à análise pelo método objetivo em que são utilizadas as medidas absolutas de desempenho (CHAKRAVARTHY, 1996), tais como Retorno sobre Ativos (ROA), Retorno sobre Patrimônio Líquido (ROE) e Taxa de Crescimento de Vendas.

A utilização de medidas de desempenho subjetivas tem sido preferida pelos pesquisadores devido às suas características, tais como sua natureza multidimensional (VENKATRAMAN; RAMANUJAM, 1987). Ademais, de acordo com Venkatraman e Ramanujam (1987), estudos evidenciam que os resultados obtidos acerca da medição do desempenho organizacional por meio de procedimentos de auto-resposta possuem relação com uma avaliação objetiva de desempenho, seja esta obtida por fontes internas das organizações, bem como por fontes externas, o que indica a existência de correlação entre as medidas subjetivas e objetivas.

Outro estudo que também aponta para a inexistência de diferença significante entre a medição subjetiva e objetiva de desempenho organizacional foi o realizado por Perin e Sampaio (1999). Além disso, estudos criticam o uso exclusivo de medidas absolutamente financeiras para medição do desempenho organizacional (ECCLES, 1991; MEYER, 1994; DRUCKER, 1995).

Dessa forma, vários são os conceitos e as formas de medição empregadas pelos pesquisadores para desempenho organizacional (VENKATRAMAN; RAMANUJAM, 1986), porém a escolha pelo método de mensuração dependerá de fatores, tais como, questão de pesquisa e disponibilidade de dados (STEERS, 1975; KANTER; BRINKERHOFF, 1981; FORD; SCHELLENBERG, 1982; CHAKRAVARTHY, 1996).

Hoque (2005) evidencia que em pesquisas realizadas com pequenas empresas são escolhidas as medidas subjetivas, uma vez que, estas não dispõem dos dados necessários, 
acarretando na inviabilidade de uma análise objetiva, com indicadores financeiros. Desta feita, a utilização de indicadores subjetivos é indicada como uma solução praticável para uma eventual inexistência de dados (PERIN; SAMPAIO, 1999), ou a impossibilidade de obtê-los (LIZOTE; VERDINELLI; NASCIMENTO, 2015). Haber e Reichel (2005), em seu estudo sobre como identificar medidas de desempenho em pequenas empresas, corroboram ao destacar a importância e a necessidade de utilização de indicadores não financeiros para medir a performance organizacional.

No presente estudo, serão utilizadas, portanto, medidas subjetivas de desempenho, através da percepção dos gestores. Tal decisão está alicerçada no fato de que este constructo representa a variável dependente no modelo e sua mensuração, como um valor em relação aos concorrentes mais próximos.

A presente pesquisa propõe a utilização do modelo de medição utilizado por Wegner, Callado e Agnes (2014), cuja escolha se deu, tendo em vista ser este um estudo efetuado com MPEs situadas na cidade de Santa Cruz do Sul, em que o desempenho organizacional, medido a partir da percepção dos empresários, de empresas inseridas em algum modelo de redes de cooperação foi confrontado com o daquelas que não estavam inseridas nenhum modelo de rede de cooperação. Além disso, a reaplicação do modelo adotado justifica-se, uma vez que, serão efetuados estudos comparativos futuros entre os resultados obtidos em ambas as pesquisas.

Conforme fora mencionado anteriormente, estudos realizados em pequenas empresas enfrentam o dilema da ausência de dados ou impossibilidade de obtê-los, por isso a análise por meio de indicadores subjetivos é indicada. Sendo assim, a auto-avaliação do empresário a respeito do desempenho de seu negócio, comparado aos anos anteriores e concorrentes do mesmo setor é comumente utilizado em pesquisas realizadas em MPEs.

De acordo com Lima (2000), os empresários são a maior fonte de informação aos pesquisadores, uma vez que possuem o domínio das informações essenciais do negócio. Isso porque "mais do que os demais, médios e grandes empresários, eles estão no centro das decisões e ações em suas empresas, sendo elementos importantes nos levantamentos de dados das pesquisas" (LIMA, 2000, p. 42).

O que se observa como característica de pequenas empresas é que o gestor possui uma auto-suficiência exacerbada, tendo em vista que, as decisões são centralizadas e todo o poder concentra-se nas mãos do dirigente, sendo as demais funções realizadas por apenas algumas pessoas, além do proprietário (MINTZBERG, 1979; LIMA, 2000). Portanto, sendo o 
empresário o maior detentor do conhecimento acerca do seu negócio, a medição do desempenho organizacional a partir da sua percepção é válida.

Ademais, alguns estudos também relativos à medição do desempenho organizacional de pequenas empresas inseridas em redes de cooperação, foram propiciados por meio da percepção dos empresários (BRASS et al., 2004; PACAGNAN, 2006; VERSCHOORE, 2006; BALESTRIN, 2008; BALESTRIN; VARGAS; FAYARD, 2008; TURETA; PAÇOCUNHA, 2008; OLIVEIRA; CÂNDIDO, 2009).

\subsection{EVIDÊNCIAS EMPÍRICAS}

O presente tópico busca elucidar os achados de pesquisas já desenvolvidas acerca da temática de desempenho organizacional de redes de cooperação horizontais constituídas por MPEs, bem como evidencia aspectos a respeito de estudos que envolvem as redes de cooperação de um modo geral. No Brasil, assim como ocorre internacionalmente, há um interesse progressivo no campo de estudos em redes de cooperação interorganizacional. É o que mostra o estudo bibliométrico realizado por Balestrin et al. (2010) por meio da análise de 116 artigos publicados nos principais veículos de difusão científica na área de estudos organizacionais, entre os anos 2000 e 2006. A presente seção limita-se, porém, a pesquisas desenvolvidas nos últimos cinco anos, entre 2010 e 2015, com o objetivo de explanar o que tem sido desenvolvido atualmente pela temática.

Com o propósito de averiguar as relações entre as organizações presentes na rede de cooperação calçadista do Vale do Rio Tijucas (SC), Andrade e Hoffmann (2010) desenvolveram sua pesquisa. Esta, por sua vez, sucedeu-se por meio da aplicação de questionário aos dirigentes empresariais locais e constatou que estar aglomerado constitui fonte de vantagem competitiva para as empresas. Os autores concluem afirmando que o tema redes vem ganhando espaço e significância, especialmente porque se caracteriza como uma alternativa das MPEs concorrerem em âmbito global, por meio da cooperação, em que dificilmente alcançariam um melhor desempenho agindo isoladamente.

Oliveira, Rezende e Carvalho (2011) desenvolveram uma pesquisa que procurou entender o fenômeno de surgimento e desenvolvimento das Redes Interorganizacionais Horizontais. Para tanto, desenvolveu-se um estudo de caso qualitativo em uma rede de compras e identificou-se que a rede de cooperação analisada tinha como principal objetivo favorecer a sua competitividade. O estudo inferiu que tal objetivo tem sido alcançado por 
meio da eficácia operacional dos participantes da rede, bem como a troca de conhecimento entre os mesmos, gerando informações coletivas e individuais.

Com a finalidade analisar e identificar quais seriam os elementos que influenciariam a referida troca de conhecimento entre os participantes de uma rede interorganizacional, Zen e Wegner (2008) desenvolveram um esquema teórico e um conjunto de proposições, a partir de um estudo exploratório, realizado na Rede Gaúcha de Incubadoras de Empresas e Parques Tecnológicos. Concluiu-se que os elementos motivadores à troca de conhecimento entre os membros de uma rede são as características da rede e das organizações participantes. Isto posta, os autores evidenciam a significância de potencializar mecanismos que intensifique a interação e coerência na rede. Adicionado a isso, corroboram com o estudo de Oliveira, Rezende e Carvalho (2011) ao incitar que as conexões estabelecidas entre os membros da rede fomentam a permuta de conhecimentos tácicos e explícitos, que se propagam no interior das organizações.

A pesquisa de Castro, Bulcagov e Hoffmann (2011) distinguiu-se das demais pesquisas desenvolvidas sobre o tema em questão, pelo fato de que, até então os estudos estavam voltados à investigação de aspectos relativos à formação e a manutenção dos relacionamentos interorganizacionais, enquanto que no estudo desenvolvido pelos autores incluiu-se, além dos fatores motivadores, facilitadores e dificultadores, o resultado dos relacionamentos, ou seja, as consequências advindas dos contatos entre organizações, uma vez que, este aspecto se caracteriza como a menos explorada. Destarte, analisaram-se os resultados obtidos por uma rede interorganizacional de cooperação do segmento varejista de materiais de construção. Estes, por sua vez, foram avaliados por meio da comparação entre o que era esperado (motivadores) e o que foi alcançado (resultados), constatando que não há correspondência entre os fatores motivadores com os resultados dos relacionamentos.

Os autores reconhecem que a rede analisada não havia atingido seu grau de maturidade, fator este que poderia comprometer o resultado da pesquisa, reforçando o fato de que o tempo é uma variável importante, tendo em vista que fatores como o desenvolvimento da confiança e agregação de conhecimento são definidos por esse.

Froehlich (2013) em seu estudo “As Contribuições das Relações Interorganizacionais para o Empreendedorismo Internacional: Um ensaio teórico" buscou construir, a partir das principais referências teóricas, um ensaio teórico sobre os seguintes temas: Empreendedorismo Internacional e Relações Interorganizacionais. De acordo com os resultados obtidos, verificou-se que as redes de cooperação são facilitadoras do processo de empreendedorismo internacional. Isto porque auxiliam no compartilhamento de 
conhecimentos, conforme já fora constatado em outras pesquisas elencadas, em decorrência dos laços firmados entre os participantes da rede. Dessa maneira, a aprendizagem mútua é amplificada e os riscos na identificação de oportunidades no mercado internacional são suavizados.

Outra pesquisa que vale ser elencada no presente tópico é a delineada por Wegner, Callado e Agnes (2014), na qual por meio de uma survey, comparou a partir da percepção do empresário o desempenho de empresas individuais, participantes de redes e participantes de franquias. Constatou-se que o desempenho das franquias superou em variadas dimensões o desempenho das empresas inseridas em redes, bem como daquelas não inseridas em nenhuma rede. Vale ressaltar também que o desempenho das redes, apesar de não ter sido superior ao das franquias, foi melhor, em algumas dimensões, do que aquelas que não estão inseridas em nenhuma rede.

Souza et al. (2014) objetivou investigar em sua pesquisa, possíveis influências de redes de cooperação no desenvolvimento das micro e pequenas empresas na cidade de Maceió, também a partir da perspectiva dos dirigentes dessas redes. De acordo com os resultados obtidos, verificou-se que as redes tem gerado renda, favorecendo a criação de empregos e capacitando as empresas, através de cursos, oficinas, encontros, palestras, entre outros. Os autores afirmam que, apesar das redes desempenharem papel essencial no desenvolvimento econômico local, os empresários não tem considerados as possibilidades estratégicas, encarando-as apenas como uma alternativa para a sobrevivência organizacional.

Wegner, Alievi e Begnis (2015) propuseram um modelo de ciclo de vida para redes de cooperação constituídas por MPEs. O estudo apontou que $68 \%$ das redes analisadas estão em declínio. Entre aquelas que estão ativas, $21 \%$ permanecem na fase de desenvolvimento, e apenas $11 \%$ alcançaram consolidação. A maioria das redes analisadas entrou na fase de declínio logo no início do ciclo de vida e foram incapazes de atingir a fase da consolidação. Os autores destacam a complexidade da rede e as expectativas dos participantes desta, evidenciando a necessidade das redes empregarem esforços de gestão para alcançar a fase de consolidação.

Observou-se, a partir dos estudos retratados que na maioria dos casos, as investigações nas redes de cooperação foram concebidas através da percepção do gestor. Adicionalmente, percebe-se também a evolução das pesquisas ao longo do tempo, de modo que vão sendo acrescentados elementos antes não investigados e novas descobertas acerca da temática são elencadas. Percebe-se, pois, que ao longo dos anos que foram contemplados no resgate empírico, o tema vem obtendo espaço e significância nas pesquisas acadêmicas, 
principalmente porque as pesquisas que em sua maioria concentram-se no sul do país veem conquistando outras regiões. 


\section{CAPÍTULO III: PROCEDIMENTOS METODOLÓGICOS}

O presente capítulo descreve o caráter da pesquisa aduzido, bem como a definição dos critérios que serão aplicados ao longo de sua consecução. No que concerne ao método utilizado para elaboração do referencial teórico, efetuou-se uma pesquisa bibliográfica em livros, artigos, dissertações, teses, entre outras fontes, com o objetivo de ilustrar acerca do desempenho organizacional, relações interorganizacionais, bem como retratar aspectos relacionados às redes de cooperação horizontais.

\subsection{TIPOLOGIA DA PESQUISA}

Para alcançar os objetivos da pesquisa, adotou-se um estudo quantitativo, do tipo survey com a finalidade de investigar, a partir de uma quantidade significativa de indivíduos, possíveis relações entre diferentes variáveis. Conforme explica Hair et al. (2005, p. 125), survey é "um procedimento para coleta de dados primários a partir de indivíduos". A pesquisa quantitativa é definida pela utilização de quantificação, "tanto nas modalidades de coleta de informações, quanto no tratamento delas, por meio de técnicas estatísticas, desde as mais simples, como percentual, média, desvio-padrão, às mais complexas, como coeficiente de correlação, análise de regressão, etc.” (RICHARDSON et al., 2011, p. 70).

O presente estudo também pode ser caracterizado como descritivo isto porque, de acordo com Gil (2008), a pesquisa descritiva tem como objetivo primordial a descrição das características de determinada população ou fenômeno ou o estabelecimento de relações entre variáveis. Desse modo, pretende-se identificar, confrontar e, portanto, descrever o desempenho organizacional de empresas inseridas em redes de cooperação e empresas não participantes de nenhum tipo de relação interorganizacional.

\subsection{POPULAÇÃO E AMOSTRA}

O universo da pesquisa foi definido com base nos dados fornecidos pelo SEBRAE do estado da Paraíba (2014). De acordo com levantamento da referida Instituição, no estado da Paraíba existem 495 MPEs que estão inseridas em uma rede de cooperação, sendo 89 destas localizadas no município de João Pessoa e o restante em outros municípios do estado, conforme é possível verificar na Tabela 1. 
Tabela 1: Universo de Redes de Cooperação localizadas no estado da Paraíba

\begin{tabular}{|c|c|c|c|c|}
\hline \multirow{2}{*}{ Atividade Econômica } & \multirow{2}{*}{ Nome da Rede } & \multicolumn{2}{|c|}{$\begin{array}{l}\text { Quantidade de empresas } \\
\text { por municípios }\end{array}$} & \multirow{2}{*}{ Tota } \\
\hline & & $\begin{array}{c}\text { João } \\
\text { Pessoa }\end{array}$ & $\begin{array}{c}\text { Outros } \\
\text { municípios }\end{array}$ & \\
\hline \multirow{7}{*}{ Mercados } & Rede de Supermercados Boa Compra & - & 13 & 13 \\
\hline & $\begin{array}{l}\text { Rede de Supermercados Gente } \\
\text { Econômica }\end{array}$ & - & 21 & 21 \\
\hline & Rede Paraíba de Supermercados & 5 & 12 & 17 \\
\hline & Rede Unilojas de Supermercados & 7 & 14 & 21 \\
\hline & Rede Nordeste de Supermercados & 2 & 9 & 11 \\
\hline & Rede de Supermercados Cidade Sorriso & - & 4 & 4 \\
\hline & Rede de Supermercados Supermix & - & 9 & 9 \\
\hline Subtotal Mercados & & 14 & 82 & 96 \\
\hline $\begin{array}{l}\text { Varejo de Materiais de } \\
\text { Construção }\end{array}$ & Rede PB Construções & 2 & 21 & 23 \\
\hline \multicolumn{2}{|c|}{ Subtotal Varejo de Materiais de Construção } & 2 & 21 & 23 \\
\hline & Redemed & 27 & N.I. & 27 \\
\hline & Redemaispharma & 18 & 155 & 173 \\
\hline \multicolumn{2}{|c|}{ Subtotal Varejo de produtos farmacêuticos } & 45 & 155 & 200 \\
\hline Serviços & Rede Unibares & - & 12 & 12 \\
\hline Subtotal Serviços & & - & 12 & 12 \\
\hline \multirow{4}{*}{ Outros } & Rede Nordeste Móveis e Eletros & 5 & 105 & 110 \\
\hline & Rede Óticas Fácil & 4 & 9 & 13 \\
\hline & Rede Superpet & 19 & 1 & 20 \\
\hline & Rede Eletrocasa & - & 21 & 21 \\
\hline \multirow[t]{2}{*}{ Subtotal Outros } & & 28 & 136 & 164 \\
\hline & Total & 89 & 406 & 495 \\
\hline
\end{tabular}

N.I. = Não informado

Fonte: Elaborado pela autora, baseado nos dados fornecidos pelo SEBRAE (2014)

No que diz respeito ao universo das MPEs que não estão inseridas em nenhum tipo de relação interorganizacional, de acordo com dados obtidos no SEBRAE ao final de 2014 o estado da Paraíba possuía 46.288 MPEs, sendo 11.756 destas localizadas no município de João Pessoa. É válido ressaltar que nesses dados não estão inclusos o total de Microempreendedores Individuais (MEI).

Tendo em vista a grande quantidade de empresas existentes em todo o estado da Paraíba, optou-se por utilizar como universo das MPEs não inseridas em nenhuma relação interorganizacional, a lista de empresas que se inscreveram para concorrer ao Prêmio MPE de competitividade do SEBRAE em 2014. O referido prêmio tem como finalidade promover o aumento da qualidade, produtividade e competitividade das MPEs brasileiras, disseminando os conceitos e práticas de gestão.

A escolha desta lista de empresas, como universo da pesquisa das MPEs não inseridas em nenhuma relação interorganizacional, ocorreu especialmente por dois motivos, a saber: o 
primeiro deles, consiste na tentativa de restringir o universo da pesquisa e consequentemente, alcançar um percentual maior de respostas obtidas em relação ao universo de empresas.

Por último, sabe-se que as MPEs que se inscrevem para concorrer ao Prêmio MPE de competitividade do SEBRAE, se auto-avaliam como competitiva, pois a inscrição no evento é realizada espontaneamente pelo responsável do empreendimento. Ao passo que, as MPEs que se inserem em redes de cooperação, assim o fazem, principalmente, buscando tornar-se competitiva no mercado. Conforme já fora mencionado no referencial teórico do presente trabalho, o fator impulsionador para a cooperação entre as empresas é a concorrência entre aquelas que não estão inseridas na rede. Logo, em um ambiente eximido de competição não haveria a necessidade de formação de redes de cooperação.

Portanto, sendo a competitividade o principal objetivo a ser alcançado pelas MPEs que se inserem em redes de cooperação, considerou-se como grupo de análise de MPEs não inseridas em nenhuma relação interorganizacional àquelas inscritas no prêmio MPE de competitividade do SEBRAE, por se auto-intitularem competitivas. Estas, por sua vez, totalizaram 200 MPEs inscritas em 2014, sendo 170 destas localizadas no município de João Pessoa, conforme se pode observar na Tabela 2.

Tabela 2: Universo e amostra da pesquisa

\begin{tabular}{lcccc}
\hline \multirow{2}{*}{ Atividade econômica } & \multicolumn{2}{c}{ Quantidade de empresas localizadas no município de João Pessoa } \\
\cline { 2 - 5 } & \multicolumn{2}{c}{ Redes de Cooperação } & \multicolumn{2}{c}{ Empresas não cooperadas } \\
\cline { 2 - 5 } & Universo & Amostra & Universo & Amostra \\
\hline Varejo de materiais de construção & 2 & 2 & 13 & 8 \\
Varejo de produtos farmacêuticos & 45 & 38 & 5 & 3 \\
Mercados & 14 & 8 & 3 & 2 \\
Serviços & - & - & 81 & 78 \\
Outros & 28 & 19 & 68 & 63 \\
\hline \multicolumn{1}{c}{ TOTAL } & $\mathbf{8 9}$ & $\mathbf{6 7}$ & $\mathbf{1 7 0}$ & $\mathbf{1 5 4}$ \\
\hline Fonyyyyyy
\end{tabular}

Fonte: Elaborado pelo autora (2015)

De acordo com os dados apresentados na Tabela 2, verifica-se que 89 empresas compõem o universo daquelas inseridas em redes de cooperação e que estão localizadas no município de João Pessoa. A amostra destas, por sua vez, é composta por 67 empresas, totalizando $75,3 \%$ do universo das empresas inseridas em redes de cooperação horizontais. No que diz respeito ao universo de empresas não cooperadas localizadas no município de João Pessoa e que participaram do prêmio MPE de competitividade do SEBRAE 2014, este totaliza 170, sendo 154 sua amostra, representando $90,6 \%$ do universo. 
Escolha do campo de pesquisa

O universo das empresas entrevistadas é composto por aquelas que estão localizadas no município de João Pessoa, capital do estado da Paraíba. Mais recentemente, foi possível observar no estado o ingresso de redes de empresas e especialmente no município de João Pessoa. Este município, por sua vez, possui o maior PIB do estado R 11.225.777 que representa $29 \%$ de todo o PIB da Paraíba, proveniente, principalmente, da indústria e comércio (IBGE, 2014). Sendo assim, o município possui uma economia essencialmente dependente dos setores secundário e terciário.

Devido a sua representatividade na economia do estado da Paraíba como um todo, optou-se por investigar as empresas localizadas apenas na cidade de João Pessoa. A amostra do presente estudo pode ser caracterizada como não probabilística e definida com base em critérios de acessibilidade e conveniência. A amostra não probabilística, por sua vez, é caracterizada pela inclusão ou exclusão dos elementos a critério do pesquisador; nem todos os elementos de uma população têm a chance de serem selecionados para a amostra [...]" (HAIR et al., 2005, p.445)

É valido ressaltar que a amostra não probabilística, como no caso da amostra da presente pesquisa, não possibilita generalizações para todo o universo. Dessa forma, as informações obtidas são relativas apenas aos elementos investigados. O objetivo, portanto, é fornecer conhecimento acerca da relação entre determinadas variáveis e não caracterizar com precisão estatística a população.

Sabe-se que a utilização de uma amostra não probabilística é menos precisa que uma amostra probabilística, porém o uso da primeira justifica-se devido às limitações de tempo, recursos e possibilidade de acesso a uma quantidade maior de indivíduos pelo pesquisador.

\subsection{INSTRUMENTO DE PESQUISA E PROCEDIMENTOS DE COLETA DE DADOS}

Para consecução da pesquisa fora adotado o mesmo questionário utilizado na pesquisa de Wegner, Callado e Agnes (2014). Os autores realizaram um estudo com MPEs situadas na cidade de Santa Cruz do Sul, comparando o desempenho organizacional de empresas que atuavam independentes de nenhuma relação interorganizacional versus empresas inseridas em 
uma rede de cooperação horizontal versus empresas atuando em franquias, que pode ser classificada como outro tipo de relação interorganizacional.

A adoção do instrumento é justificada, tendo em vista a pretensão do pesquisador em dar prosseguimento aos estudos iniciados por Wegner, Callado e Agnes (2014). É ansiado pelo pesquisador debater mais sobre o conteúdo que ainda não está consolidado e realizar estudos comparativos a partir dos resultados obtidos nas duas pesquisas. Ittner \& Larcker (2001) evidenciam a importância de promover o prosseguimento dos estudos, uma vez que, a não continuidade nas pesquisas acarreta em discussões superficiais acerca dos temas investigados, o que consequentemente minimiza as chances de publicações.

Para elaboração do questionário, Wegner, Callado e Agnes (2014) tomaram por base o estudo de Santos (2008), tendo em vista ser este o mais apropriado para MPEs. A proposta desenvolvida por Santos (2008) sugere, a partir da percepção do respondente em relação ao concorrente do setor, medir o desempenho da empresa. Assim como este, outros estudos analisam as contribuições da rede para o desempenho da empresa também através da percepção dos empresários (BRASS et al., 2004; PACAGNAN, 2006; VERSCHOORE; BALESTRIN, 2008; BALESTRIN; VARGAS; FAYARD, 2008, TURETA; PAÇO-CUNHA, 2008; OLIVEIRA; CÂNDIDO, 2009).

No entanto, no instrumento utilizado na presente pesquisa, foi acrescentada uma nova categoria de perguntas para a caracterização de aspectos relacionados com a contabilidade gerencial. O objetivo deste novo grupo de perguntas é observar a relevância da contabilidade dentro da organização, no que diz respeito à visão do empresário sobre a contabilidade gerencial, bem como a utilização de informações contábeis para formação de preço, planejamento financeiro, entre outros aspectos. Adicionalmente, pretende-se observar se as empresas que apresentarem melhor desempenho organizacional se utilizam de informações contábeis, ou se o referido uso é indiferente. As perguntas que compõe esse novo bloco foram elaboradas a partir da leitura de artigos sobre o tema.

\section{Estrutura do questionário}

A versão final do questionário de pesquisa (Apêndice 1) foi estruturado em sete blocos contendo 27 perguntas no total. Foram utilizadas perguntas de múltipla escolha sendo estas perguntas de julgamento, cuja resolução necessita de uma avaliação do respondente de acordo com uma escala de intensidade crescente ou decrescente e as perguntas de fato, que se referem aos dados do respondente ou objeto de pesquisa, como por exemplo, tempo de 
existência da empresa, tempo de atuação no cargo, tempo de participação na rede, entre outras.

O primeiro bloco aborda seis perguntas a respeito do perfil da empresa. O segundo bloco, composto por cinco itens, trouxe questionamentos acerca da percepção do empresário sobre seu desempenho no último ano quando comparado aos seus concorrentes, abordando as seguintes perspectivas: "satisfação dos clientes", "satisfação dos funcionários", "crescimento da empresa" e "lucratividade da empresa". No terceiro bloco os entrevistados responderam a duas questões sobre seu desempenho, no que diz respeito ao "crescimento da empresa" e "lucratividade da empresa" quando comparado ao período anterior.

No quarto bloco, os empresários também responderam a duas questões acerca do desempenho da empresa de um modo geral, uma pergunta comparando seu desempenho geral aos seus concorrentes e a outra ao seu próprio desempenho do período anterior. O quinto bloco traz um único questionamento acerca da competitividade da empresa, ao passo que o sexto bloco aborda quatro perguntas sobre a utilização das informações da contabilidade gerencial voltadas ao processo decisório. Por fim, no bloco sete são realizados questionamentos sobre o perfil do respondente.

Ao responder os inquéritos investigativos, os empresários terão que equiparar a conjuntura de suas empresas com as dos concorrentes do setor, fazendo uso da seguinte escala: "muito pior que a média", "pior que a média", "igual à média", "melhor que a média" e "muito melhor que a média". Essa mensuração proscreve as dessemelhanças setoriais e assente a coleta de dados com empresas de distintos segmentos de negócio, sem detrimentos às suas análises.

\section{Pré-teste do questionário de pesquisa}

A versão preliminar do questionário de pesquisa foi testada em novembro de 2014 com um gestor de uma organização que não participa de nenhum tipo de relação interorganizacional, mas que já foi integrante de uma rede de cooperação horizontal. $O$ empresário respondeu às perguntas do referido questionário na presença do pesquisador e apontou questões que, por ventura, não apresentaram clareza, objetividade ou que pudesse inibi-lo para responder.

$\mathrm{O}$ instrumento de pesquisa foi revisado e aprimorado com base nas observações do empresário. Dessa forma, um novo pré-teste foi realizado, ainda em novembro de 2014, com outro empresário, de uma empresa que não está inserida em nenhum tipo de relação 
interorganizacional. Assim como na primeira avaliação o respondente averiguou aspectos sobre a clareza e objetividade das questões. Ademais, foi indagado ao empresário acerca do tempo de preenchimento do questionário, que foi finalizado em, aproximadamente, 25 minutos, sendo este um tempo considerado satisfatório pela pesquisadora.

\section{Coleta de dados}

Os dados foram coletados por meio da aplicação do questionário contendo perguntas que têm como finalidade responder aos objetivos, geral e específicos, os quais foram propostos na pesquisa. Os questionários foram preenchidos pelo próprio respondente, sempre na presença do pesquisador ou de um auxiliar do pesquisador, para o caso de eventuais dúvidas na forma do preenchimento ou outras.

A maior parte dos questionários foi respondida pelo sócio-proprietário da MPE (85\%), ao passo que em $11 \%$ das situações o gerente foi o responsável pelo preenchimento do instrumento e em apenas $4 \%$ da amostra os questionários foram respondidos por outros funcionários, a exemplo de auxiliar administrativo, auxiliar contábil e até mesmo dois que se intitularam "braço-direito do dono" e "faz tudo". Dessa maneira, as chances de viés nos dados pelo fato do entrevistado não possuir capacidade de responder as questões com propriedade são minimizadas, tendo em vista que $96 \%$ dos respondentes é sócio-proprietário ou gerente.

O período de coleta de dados sucedeu-se entre meados de abril a meados de novembro de 2015, totalizando sete meses de coleta de dados. Vale ressaltar que durante todo o período de coleta de dados foi garantido o anonimato do respondente.

\subsection{HIPÓTESE E OPERACIONALIZAÇÃO DAS VARIÁVEIS}

De acordo com o que foi exposto no referencial teórico do presente trabalho, tomando por base a literatura apresentada, bem como as evidências empíricas apontadas, elaborou-se, a partir do problema de pesquisa, a seguinte hipótese alternativa:

No tocante às MPEs, a inserção em redes de cooperação horizontais conduz a um desempenho organizacional superior àquelas que atuam independente de qualquer relação interorganizacional. 
A presente pesquisa considera desempenho organizacional de MPEs, os resultados financeiros (crescimento das vendas, participação de mercado, lucratividade) e resultados não financeiros (qualidade dos produtos e serviços, satisfação dos clientes, satisfação dos funcionários), conforme revisão apresentada por Provan e Sydow (2008).

Portanto, a medição do desempenho organizacional foi realizada por meio de um conjunto de itens, a saber:

- Satisfação dos clientes;

- Satisfação dos funcionários;

- Crescimento da empresa;

- Lucratividade da empresa; e

- Desempenho geral.

Para cada item de medição de desempenho foi questionado ao empresário a sua percepção a respeito de aspectos associados à medida de desempenho, conforme pode ser observado no Quadro 4.

Quadro 4: Operacionalização das Variáveis de Medição do Desempenho Organizacional a partir da percepção dos empresários

\begin{tabular}{|c|l|}
\hline Medida de Desempenho & \multicolumn{1}{|c|}{ Variáveis utilizadas para medição do desempenho } \\
\hline \multirow{4}{*}{ Satisfação dos clientes } & Valor agregado para o cliente \\
\cline { 2 - 2 } & Número de reclamações de clientes \\
\cline { 2 - 2 } & Fidelidade dos clientes \\
\cline { 2 - 2 } & Retenção de novos clientes \\
\cline { 2 - 2 } & Satisfação geral dos clientes \\
\hline \multirow{5}{*}{ Satisfação dos funcionários } & Rotatividade dos funcionários \\
\cline { 2 - 2 } & Investimento no desenvolvimento e treinamento dos funcionários \\
\cline { 2 - 2 } & Política de Remuneração e Benefícios \\
\cline { 2 - 2 } & Plano de Carreira \\
\cline { 2 - 2 } & Clima organizacional \\
\cline { 2 - 2 } & Satisfação geral dos funcionários \\
\hline \multirow{5}{*}{ Crescimento da empresa } & Crescimento da participação de mercado \\
\cline { 2 - 2 } & Crescimento do ativo total \\
\cline { 2 - 2 } & Crescimento do faturamento \\
\cline { 2 - 2 } & Crescimento do lucro líquido \\
\cline { 2 - 2 } & Crescimento do número de funcionários \\
\hline \multirow{2}{*}{ Lucratividade da empresa } & Retorno sobre o capital investido \\
\cline { 2 - 2 } & Lucro líquido sobre as vendas \\
\hline \multirow{2}{*}{ Desempenho Geral } & Desempenho geral comparado aos concorrentes \\
\cline { 2 - 2 } & Desempenho geral comparado ao ano anterior \\
\hline Fonte: Elaborado pela autora (2015) & \\
\hline
\end{tabular}

Fonte: Elaborado pela autora (2015)

Os itens foram analisados por meio da aplicação de questões com uma escala de 1 a 5 do tipo Likert, em que 1 corresponde ao posicionamento "muito pior que a média", 2 equivale a "pior que a média", 3 significa "igual a média", 4 corresponde a "melhor que a 
média" e 5 equivale a "muito melhor que a média". O conjunto de respostas obtidas dos gestores das empresas indicará a dimensão de satisfação do respondente (satisfação alta, satisfação média ou satisfação alta) possibilitando identificar o desempenho organizacional e comparar os grupos de empresas inseridas em redes de cooperação versus aquelas não inseridas em nenhuma relação interorganizacional.

A partir dos resultados obtidos para cada medida de desempenho foi calculado um escore que foi utilizado como indicador de desempenho. A partir de todos os escores obtidos, foi elaborado um escore geral de medida de desempenho, conforme Quadro 5.

Quadro 5: Composição do escore total para medição do desempenho total

\begin{tabular}{|c|l|}
\hline Escore & \multicolumn{1}{|c|}{ Descrição } \\
\hline Escore 1 & $\begin{array}{l}\text { Escore do desempenho medido pela satisfação dos clientes quando comparado aos } \\
\text { concorrentes }\end{array}$ \\
\hline Escore 2 & $\begin{array}{l}\text { Escore do desempenho medido pela satisfação dos funcionários quando comparado } \\
\text { aos concorrentes }\end{array}$ \\
\hline Escore 3 & $\begin{array}{l}\text { Escore do desempenho medido pelo crescimento da empresa quando comparado aos } \\
\text { concorrentes }\end{array}$ \\
\hline Escore 4 & $\begin{array}{l}\text { Escore do desempenho medido pela lucratividade da empresa quando comparado aos } \\
\text { concorrentes }\end{array}$ \\
\hline Escore 5 & $\begin{array}{l}\text { Escore do desempenho medido pelo crescimento da empresa quando comparado ao } \\
\text { ano anterior }\end{array}$ \\
\hline Escore 6 & $\begin{array}{l}\text { Escore do desempenho medido pela lucratividade da empresa quando comparado ao } \\
\text { ano anterior }\end{array}$ \\
\hline Escore 7 & $\begin{array}{l}\text { Escore do desempenho medido pela percepção geral do respondente comparado aos } \\
\text { concorrentes e ao ano anterior }\end{array}$ \\
\hline Escore Total & Escore 1 + Escore 2 + Escore 3 + Escore 4 + Escore 5 + Escore 6 + Escore 7 \\
\hline
\end{tabular}

Fonte: Elaborado pela autora (2015)

É valido destacar que para as medidas de desempenho "Crescimento da empresa" e "Lucratividade da empresa", além do respondente comparar a respectiva medida em relação aos seus concorrentes, foram efetuadas mais duas perguntas, em que o empresário compara a respectiva medida em relação ao seu resultado do período anterior.

\subsection{TRATAMENTO DOS DADOS}

A análise dos dados procedeu-se através do auxílio do pacote estatístico SPSS ${ }^{\circledR}$ versão 20.0 para Windows no qual, realizou-se a estatística descritiva e testes não paramétricos. A priori, as análises de estatística descritiva permitiram alcançar o primeiro e segundo objetivos específicos, ou seja, descrever o perfil das MPEs inseridas em redes 
horizontais de cooperação e das MPEs que atuam independente de qualquer relação interorganizacional e descrever o perfil dos entrevistados das MPEs inseridas em redes horizontais de cooperação e dos entrevistados das MPEs que atuam independente de qualquer relação interorganizacional, respectivamente.

Aspirando responder o problema de pesquisa e conseguir cumprir do primeiro ao quarto objetivos específicos adotou-se os testes Qui-quadrado (para variáveis categóricas) e o teste Mann-Whitney (para as variáveis contínuas ou intervalares que não possuem distribuição normal), sabendo que os resultados decididos como estatisticamente significantes possuem níveis descritivos (valor-p) menores que 0,05 .

O teste U de Mann-Whitney viabilizou a comparação das medianas obtidas para cada variável, que se almejou confrontar, dos grupos de MPEs inseridas em redes horizontais de cooperação e das MPEs que atuam independente de qualquer relação interorganizacional. A escolha do teste justifica-se primeiramente porque possibilita o confronto de duas amostras independentes de tamanhos desiguais. Além disso, o teste considera a hipótese nula de que as medianas são iguais, diferentemente do teste t que verifica a igualdade das médias. Portanto, o teste escolhido evita a seguinte situação: quando há uma amostra com um único outlier em algum dos grupos, apenas em razão deste, o referido grupo apresenta uma média alta (supondo que o outlier seja muito superior) que consequentemente irá elevar a estatística do teste $t$, que gerará um valor-p baixo (SIEGEL; CASTELLAN, 2006).

Sabendo que os dados devem apresentar uma distribuição normal, aplicou-se o teste de normalidade Kolmogorov-Smirnov, uma vez que o tamanho da amostra é superior a 50 empresas. Considerando as hipóteses $\mathrm{H}_{0}$ (distribuição normal) e $\mathrm{H}_{1}$ (distribuição não normal) a hipótese $\mathrm{H}_{0}$ é rejeitada ao nível de significância de 5\%, ou seja, nos casos em que o valor-p for menor que 0,05 a distribuição não é normal (CORRAR; PAULO; DIAS FILHO, 2012).

Por fim, é importante destacar que foi calculado o Alfa de Cronbach, que corresponde a uma ferramenta estatística que quantifica a confiabilidade do questionário de 0 a 1 , sendo 0,70 o valor mínimo aceitável para o alfa, uma vez que, valores inferiores a este representam baixa consistência interna da escala utilizada. De acordo com Corrar, Paulo e Dias Filho (2012, p. 65) o cálculo do alfa é utilizado “em pesquisas empíricas que envolvem testes com vários itens, que abrangem variáveis aleatórias latentes, por exemplo, a avaliação da qualidade de um questionário com uma métrica de perfil latente". Adicionalmente, pode-se considerar que este método está empregado em várias pesquisas e é a análise de confiabilidade mais comumente utilizada (CORRAR; PAULO; DIAS FILHO, 2012). 


\section{CAPÍTULO IV: APRESENTAÇÃO E DISCUSSÃO DOS RESULTADOS DA PESQUISA}

O presente capítulo descreve os resultados decorrentes da pesquisa empírica realizada com as empresas participantes de redes de cooperação horizontal e empresas não participantes de nenhuma relação interorganizacional. Inicialmente, apresenta-se o perfil das empresas e em seguida o perfil dos respondentes é caracterizado. Na sequência, são expostos os resultados referentes à análise de desempenho organizacional de cada grupo de empresa investigado efetuando às devidas comparações, a fim de alcançar o objetivo geral da pesquisa.

\subsection{CARACTERIZAÇÃO DAS EMPRESAS PARTICIPANTES DA PESQUISA}

O presente tópico tem como finalidade atender ao primeiro objetivo específico que consiste em descrever o perfil das MPEs inseridas em redes horizontais de cooperação e das MPEs que atuam independente de qualquer relação interorganizacional e verificar se há diferença entre os respectivos perfis.

A amostra da pesquisa é composta por 221 empresas, sendo 67 inseridas em redes de cooperação horizontais e 154 empresas não inseridas em nenhum tipo de relação interorganizacional, representando $30,3 \%$ e $69,7 \%$ da amostra, respectivamente. Com a finalidade de facilitar a exposição dos resultados, utilizou-se para as empresas inseridas em redes de cooperação horizontal a seguinte nomenclatura: "empresas cooperadas", ao passo que para empresas não participantes de redes de cooperação nomeou-se "empresas não cooperadas".

No primeiro bloco de perguntas do instrumento utilizado no estudo, buscou-se identificar o perfil das empresas com a finalidade de caracterizá-las. Os resultados, expostos na Tabela 3, evidenciam que em relação ao tempo de existência das empresas, as cooperadas possuem maior tempo quando comparadas com as empresas não cooperadas, visto que $77,6 \%$ das primeiras possuem tempo superior a sete anos de existência em contrapartida a 70,2\% das outras.

Ao verificar o tempo de participação das empresas na rede de cooperação constata-se que não há nenhuma empresa com mais de 12 anos de cooperação, sendo a maioria $(82,1 \%)$ com tempo de existência entre 1 e 6 anos e apenas 17,9\% com tempo de existência entre 7 e 12 anos. Isso significa que a partir da metade do seu tempo de existência as empresas optaram 
por ingressar em uma rede de cooperação, evidenciando que antes de adentrar na rede a empresa possuía tempo considerável de experiência no mercado.

Tabela 3: Perfil das empresas cooperadas e não cooperadas e resultados do teste Qui-quadrado

\begin{tabular}{|c|c|c|c|c|c|c|}
\hline \multirow{2}{*}{\multicolumn{2}{|c|}{ Variável }} & \multicolumn{2}{|c|}{ Cooperada } & \multicolumn{2}{|c|}{ Não cooperada } & \multirow{2}{*}{$\begin{array}{c}\text { Qui- } \\
\text { Quadrado } \\
\end{array}$} \\
\hline & & $\mathrm{n}$ & $\%$ & $\mathrm{n}$ & $\%$ & \\
\hline $\begin{array}{c}\text { Tempo de existência } \\
\text { da empresa } \\
\text { (em anos) }\end{array}$ & $\begin{array}{c}1 \text { a } 6 \\
7 \text { a } 12 \\
>12\end{array}$ & $\begin{array}{l}15 \\
21 \\
31\end{array}$ & $\begin{array}{l}22,4 \\
31,3 \\
46,3\end{array}$ & $\begin{array}{l}46 \\
36 \\
72\end{array}$ & $\begin{array}{l}29,9 \\
23,4 \\
46,8\end{array}$ & 0,350 \\
\hline $\begin{array}{l}\text { Porte da empresa } \\
\text { (número de } \\
\text { funcionários) }\end{array}$ & $\begin{array}{c}1 \text { a } 6 \\
7 \text { a } 12 \\
>12\end{array}$ & $\begin{array}{c}23 \\
35 \\
9\end{array}$ & $\begin{array}{l}34,3 \\
52,3 \\
13,4\end{array}$ & $\begin{array}{l}49 \\
44 \\
61\end{array}$ & $\begin{array}{l}31,8 \\
28,6 \\
39,6\end{array}$ & $<0,001^{*}$ \\
\hline Segmento & $\begin{array}{c}\text { Materiais de Construção } \\
\text { Farmácia } \\
\text { Mercados } \\
\text { Outros } \\
\text { Serviços } \\
\end{array}$ & $\begin{array}{c}2 \\
38 \\
8 \\
19 \\
- \\
\end{array}$ & $\begin{array}{c}3,0 \\
56,7 \\
11,9 \\
28,4 \\
- \\
\end{array}$ & $\begin{array}{c}8 \\
3 \\
2 \\
63 \\
78 \\
\end{array}$ & $\begin{array}{c}5,3 \\
1,9 \\
1,3 \\
40,9 \\
50,6 \\
\end{array}$ & $0,001 *$ \\
\hline $\begin{array}{c}\text { Tempo de } \\
\text { participação na rede } \\
\text { de cooperação (em } \\
\text { anos) }\end{array}$ & $\begin{array}{l}1 \text { a } 6 \\
7 \text { a } 12\end{array}$ & $\begin{array}{l}55 \\
12\end{array}$ & $\begin{array}{l}82,1 \\
17,9\end{array}$ & - & - & - \\
\hline
\end{tabular}

Fonte: Elaborado pela autora, baseado nos dados coletados (2015)

Adicionalmente, o fato das empresas possuírem pouco tempo na rede de cooperação pode ser explicado tendo em vista que, o surgimento destas é um acontecimento recente no Brasil e em especial na Paraíba, conforme corrobora Wegner (2011) quando nos achados de sua pesquisa identificou um tempo médio de existência das redes de 6 anos e meio. No caso da presente pesquisa, o tempo médio de participação na rede está em torno de 4 anos, ao passo que aquela que possui mais tempo está há 10 anos e a que possui menos tempo está apenas há 6 meses inserida na rede.

No que diz respeito ao porte das MPEs, analisou-se a quantidade de funcionários, incluindo familiares, para cada grupo de empresa. De acordo com os dados obtidos, constatou-se que, em relação às empresas cooperadas, apenas 13,4\% do total da amostra possuem mais de 12 funcionários, enquanto que 80,6\% possuem uma quantidade inferior ou igual a 12 funcionários. Relativo às empresas não cooperadas, constatou-se que a maioria das empresas $(68,2 \%)$ possui número superior ou igual a 7 funcionários, sendo o percentual daquelas que possuem mais de 12 funcionários $(39,6 \%)$ o mais representativo entre os percentuais obtidos a partir da classificação estabelecida. Este dado indica que as empresas não cooperadas em sua maioria possuem maior número de funcionários quando comparada às empresas cooperadas. 
Tal fato corrobora com a literatura (BALESTRIN; VARGAS, 2003), evidenciando que as redes de cooperação horizontal atraem maior participação de empresas de pequeno porte em busca da sobrevivência. As empresas cooperadas com maior e menor quantidade de funcionários, incluindo familiares, possuem 4 e 20 empregados, respectivamente. Esta informação isolada pode não chamar atenção, porém quando confrontada com as empresas não cooperadas que possuem até 72 funcionários, constata-se uma diferença considerável entre os pontos máximo de cada grupo observado.

Em relação aos segmentos os quais os grupos de empresa pertencem, constatou-se que há maior concentração das empresas cooperadas no varejo de produtos farmacêuticos (56,7\%). Em seguida tem-se o segmento "outros" com 28,4\%, em que se enquadram os pet shops e as óticas, com 11,9\% o segmento "mercados", 3\% o segmento de varejo de materiais de construção. Vale salientar que apesar de não existir a presença de empresas cooperadas no segmento "serviços" os pet shops trabalham ao mesmo tempo com comércio e serviços, porém a classificação escolhida pelos respondentes para representar o segmento foi "outros", tendo em vista ser o comércio mais representativo para estes.

O fato da maioria das empresas cooperadas está concentrada no segmento de varejo de produtos farmacêuticos, pode ser justificado pela presença de duas grandes redes de farmácia no município investigado. Adicionalmente, verifica-se que conforme Balestrin e Vargas (2003) descrevem, as MPEs inseridas em redes de cooperação operam em um segmento específico de mercado. No caso das empresas investigadas o setor mais presente nas redes é o comércio, com os seguintes segmentos específicos: varejo de produtos farmacêuticos, pet shops e supermercados.

Nas empresas inseridas em redes de cooperação não há a presença de nenhuma empresa que atue exclusivamente no setor de serviços. Tal informação corrobora com pesquisa de Wegner (2011) que ao investigar 34 redes de empresas, constatou que somente uma delas atua no setor serviços (cursos e treinamentos) e cinco atuam em ambos os setores ao mesmo tempo, comércio e serviços. Portanto, pode-se dizer que ainda não é comum a existência de redes de cooperação provenientes do setor serviços.

Diferentemente das empresas cooperadas, as empresas não cooperadas possuem maior concentração no segmento serviços $(50,6 \%$ ), seguida de outros com 40,9\% (englobando pet shops, escolas, lojas de artigos para informática, entre outros), varejo de materiais de construção $(5,3 \%)$, varejo de produtos farmacêuticos $(1,9 \%)$ e mercados $(1,3 \%)$.

Com o objetivo de verificar se há diferença entre os grupos de empresas cooperadas e não cooperadas, realizou-se o teste não paramétrico, Qui-quadrado para as variáveis de 
caracterização do perfil das empresas. Os resultados, dispostos na Tabela 3, indicam que em relação ao "tempo de existência da empresa", não há diferença significante, ou seja, o fato da empresa ser cooperada ou não, não irá influenciar no tempo de existência da mesma.

Em contrapartida, ao aplicar o teste Qui-quadrado para os cruzamentos porte da empresa por grupo e segmento por grupo, verificou-se que existe diferença significante, uma vez que o valor-p é menor que 0,001 e igual a 0,001, respectivamente. Por conseguinte, há a influência do grupo sobre estas variáveis, ou seja, o fato de uma empresa ser de determinado segmento ou possuir certa quantidade de funcionários, influencia na ocorrência desta ser ou não uma empresa cooperada.

Concernente à diferença observada nos grupos quanto ao segmento ao qual pertencem, Balestrin e Vargas (2003, p. 3), afirmam que "as MPEs cooperadas operam em um segmento específico de mercado". Observou-se nesse caso que as empresas inseridas em redes possuem maior concentração no setor comércio, diferentemente das empresas não cooperadas que estão, em sua maioria, classificadas no setor serviços.

Sabendo que as variáveis, tempo e segmento estão relacionadas com o grupo, utilizouse estas variáveis que juntas formam uma tabela tridimensional para aplicar a técnica estatística multivariada Análise de Correspondência. A referida técnica permite representar, geralmente em duas dimensões, pontos que são as categorias das variáveis e determina as distâncias entre estes pontos que são interpretadas como associações entre as categorias. Os resultados obtidos para sete dimensões encontram-se na Tabela 4.

Tabela 4: Análise de Correspondência Múltipla para a tabela multidimensional Porte $x$ Segmento $x$ Grupo com solução completa em sete dimensões

\begin{tabular}{c|c|c|c|c}
\hline \multirow{2}{*}{ Dimensão } & \multicolumn{3}{|c}{ Variância Explicada } \\
\cline { 2 - 4 } & Alfa de Cronbach & $\begin{array}{c}\text { Total } \\
\text { (Eigenvalue) }\end{array}$ & Inércia & \% de variância \\
\hline 1 & 0,708 & 1,894 & 0,631 & 63,136 \\
2 & 0,315 & 1,266 & 0,422 & 42,200 \\
3 & 0,208 & 1,161 & 0,387 & 38,686 \\
4 & 0,000 & 1,000 & 0,333 & 33,333 \\
5 & $-0,296$ & 0,835 & 0,278 & 27,834 \\
6 & $-0,997$ & 0,601 & 0,200 & 8,118 \\
\hline & $-4,659$ & 0,244 & 0,081 & - \\
\hline Total & & 7,000 & 2,333 & 33,333 \\
\hline
\end{tabular}

Fonte: Elaborado pela autora, baseado nos dados coletados (2015)

O número máximo de dimensões é determinado a partir da seguinte equação: 
Número de dimensões $=\mathrm{K}-\mathrm{Q}$,

onde,

K é a soma do número de níveis de cada variável e

Q é o número de variáveis.

Logo:

$$
\mathrm{K}-\mathrm{Q}=(3+5+2)-3=7 \text { dimensões. }
$$

A variância total explicada é igual a:

$$
\frac{\mathrm{K}}{\mathrm{Q}}-1,
$$

Portanto:

$$
\frac{(3+5+2)}{3}-1=2,333
$$

O valor 2,333 corresponde ao total da coluna inércia. Portanto, a variabilidade explicada por duas dimensões é dada por:

$$
2 \times \frac{2,333}{7} \times 100=66,6 \% \text {. }
$$

Admitindo-se duas dimensões como solução na Análise de Correspondência deste problema, obtém-se 66,6\% da variância total. Ademais, quando observada a medida Alfa de Cronbach deve-se, também, optar pela análise em duas dimensões, uma vez que, a partir da solução com duas dimensões tem-se um valor baixo para esta medida.

Portanto, admite-se a solução com duas dimensões, em que a Dimensão 1 (eixo X) possui $63,1 \%$ da variância explicada $(66,6 \%)$ e a Dimensão 2 (eixo Y) explica 42,2\% da variância explicada (66,6\%). Ambos os eixos (X e Y) possuem relevância, ainda que o eixo X possua maior poder explicativo quando comparado ao eixo Y. Na Figura 2, é possível verificar a disposição das categorias das variáveis, grupo, porte da empresa e segmento no mapa de correspondência que reflete as associações entre as categorias.

De acordo com a Figura 2 pode-se observar que a Dimensão 1 permite perceber dois clusters: o primeiro é o das empresas não cooperadas, com os segmentos "serviços", "outros" e com porte de empresa entre 1 e 6 funcionários. O segundo é o das empresas cooperadas, 
com o segmento "varejo de produtos farmacêuticos" e "mercados" e sendo aquelas que possuem de 7 a 12 funcionários.

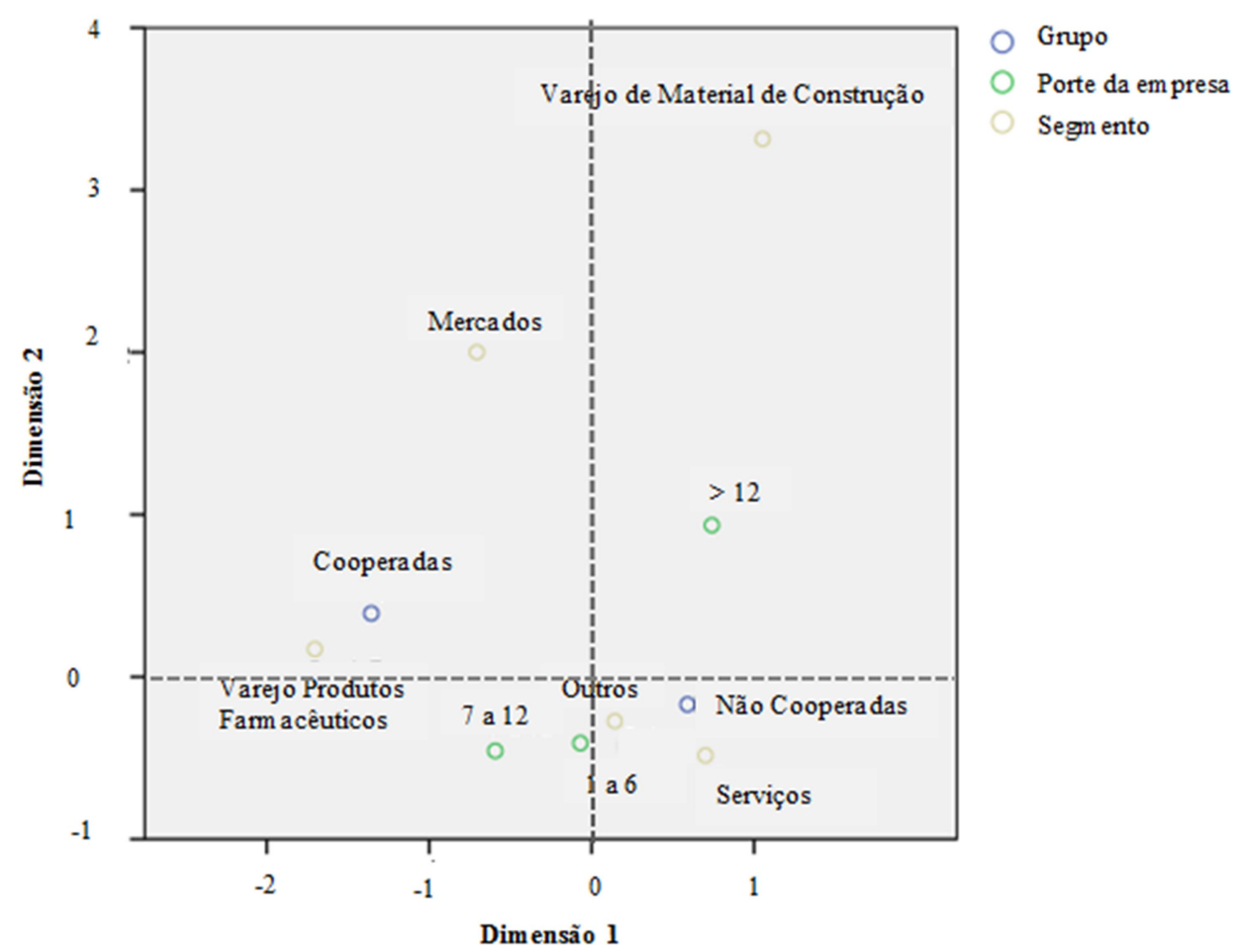

Figura 2: Representação das categorias de grupos de empresas cooperadas e não cooperadas X Porte da empresa X Segmento da empresa no plano bidimensional

Na Dimensão 2, o cluster percebido pelas empresas não cooperadas é composto pelo segmento "serviços" e "outros", com número de funcionários entre 1 e 12. Ao passo que o cluster das empresas cooperadas é constituído pelos segmentos "varejo de produtos farmacêuticos", "mercados" e porte de empresa com número de funcionários maior que 12. Vale salientar que, ainda que os pontos "porte de empresa maior que 12 funcionários" e "varejo de material de construção" estejam contidos na Dimensão 2, encontram-se distantes do ponto "empresas cooperadas".

A Tabela 5 apresenta as medidas descritivas do perfil da empresa, tais como média, mediana, desvio padrão, ponto mínimo e ponto máximo. Além das referidas medidas, também apresenta o teste de Mann-Whtiney, utilizado para identificar se existe diferença estatística significante entre os grupos de empresas cooperadas e não cooperadas, com relação às variáveis: tempo de existência da empresa, porte da empresa e tempo de existência da rede de cooperação. 
Tabela 5: Medidas descritivas do perfil da empresa e seus testes de Mann-Whitney para comparação dos grupos das empresas cooperadas e não cooperadas

\begin{tabular}{|c|c|c|c|c|c|c|c|}
\hline Variável & Empresa & Média & $\begin{array}{l}\text { Desvio } \\
\text { Padrão }\end{array}$ & Mediana & Mínimo & Máximo & $\begin{array}{l}\text { p - valor } \\
\text { (Mann- } \\
\text { Whitney) }\end{array}$ \\
\hline \multirow{2}{*}{$\begin{array}{c}\text { Tempo de existência } \\
\text { da empresa } \\
\text { (em anos) }\end{array}$} & \multirow{2}{*}{$\begin{array}{l}\text { Cooperada } \\
\text { Não } \\
\text { Cooperada }\end{array}$} & 12,81 & 7,23 & 11,00 & 1 & 27 & \multirow[b]{2}{*}{0,984} \\
\hline & & 13,37 & 8,95 & 11,00 & 2 & 40 & \\
\hline \multirow{2}{*}{$\begin{array}{l}\text { Porte da empresa } \\
\text { (número de } \\
\text { funcionários) }\end{array}$} & \multirow{2}{*}{$\begin{array}{l}\text { Cooperada } \\
\text { Não } \\
\text { Cooperada }\end{array}$} & 8,48 & 3,78 & 7,00 & 4 & 20 & \multirow[b]{2}{*}{$0,015^{*}$} \\
\hline & & 11,86 & 9,01 & 10,00 & 3 & 72 & \\
\hline \multicolumn{2}{|c|}{$\begin{array}{l}\text { Tempo de participação na rede de } \\
\text { cooperação (em anos) }\end{array}$} & 4,63 & 2,36 & 5,00 & 0 & 10 & - \\
\hline
\end{tabular}

* significante a $5 \%$.

Fonte: Elaborado pela autora, baseado nos dados coletados (2015)

Verifica-se que o tempo médio de existência das empresas cooperadas e não cooperadas, são aproximados e correspondem a 12,81 e 13,37 anos, respectivamente, ao passo que, a mediana para os dois grupos possui valores iguais a 11,0. Os pontos mínimo e máximo são, respectivamente 1 e 27 para empresas cooperadas e 2 e 40 para empresas não cooperadas.

Para complemento da análise aplicou-se o teste de Mann-Whitney, com o objetivo de verificar se os grupos de empresas cooperadas e não cooperadas possuíam diferença estatisticamente significante no que diz respeito ao tempo de existência da empresa. Para tal, efetuou-se o teste de normalidade que, por sua vez, avalia a distribuição dos dados verificando se possui ou não distribuição normal. Dessa forma, sabendo que a amostra tem tamanho superior a 50 aplicou-se o teste de normalidade Kolmogorov-Smirnov, obtendo um p-valor menor que 0,001 . A partir do resultado obtido no teste, é possível concluir que esta variável não possui distribuição normal o que conduz à aplicação do teste de Mann-Whitney, teste não paramétrico aplicável a duas amostras independentes, para realizar a comparação entre os grupos de empresas cooperadas versus não cooperadas. O p-valor obtido no teste, igual a 0,984, evidencia que não há diferença estatística significante no tempo mediano da empresa entre o grupo de empresas cooperadas e o grupo de empresas não cooperadas, corroborando com o resultado obtido no teste Qui-quadrado.

O tempo médio de participação da rede de cooperação equivale a 4,63 anos, menos da metade do tempo de existência destas empresas. Conforme já fora mencionado, o estabelecimento de redes de cooperação no Brasil é recente, fato este confirmado pelos resultados obtidos na pesquisa. Os pontos mínimo e máximo são, 0 e 10, respectivamente, sendo 6 meses o menor tempo de uma empresa participando de uma rede.

Em relação ao "porte das empresas", medido pela quantidade de funcionários contratados, incluindo familiares, verificou-se que as empresas cooperadas e empresas não 
cooperadas, possuem média igual a 8,48 e 11,86, respectivamente. Indicando que as empresas cooperadas possuem menor número de funcionários em relação às empresas não cooperadas.

Da mesma forma que se efetuou o teste de normalidade Kolmogorov-Smirnov, para a variável "tempo de existência das empresas" também foi realizado para a variável "porte das empresas", obtendo-se um p-valor menor que 0,001. Portanto, foi aplicado o teste de MannWhitney obtendo-se um p-valor de 0,015 permitindo decidir que há diferença significante entre os grupos de empresas cooperadas e não cooperadas no que concerne ao porte da empresa, concordando com o teste Qui-quadrado efetuado.

A diferença observada quanto ao porte (número de funcionários) pode ser justificada pelo fato das empresas cooperadas possuírem as mesmas características, sendo uma delas o número reduzido de funcionários, com média de 8 funcionários. As não cooperadas por sua vez, apesar de possuírem média de 12 funcionários, apenas 4 a mais do que as empresas cooperadas, apresentam desvio-padrão elevado $(9,01)$ para esta medida. Isto indica que a amostra não é tão homogênea quanto a amostra das empresas cooperadas, fato este que pode ser comprovado ao confrontar os pontos mínimo e máximo de cada grupo, sendo para as empresas cooperadas 4 e 20, respectivamente e para as empresas não cooperadas 3 e 72, respectivamente. Portanto verifica-se maior homogeneidade na amostra das cooperadas quanto ao número de funcionários, sendo esta uma característica peculiar das redes de cooperação.

Tendo em vista ser esta uma diferença significativa, conforme resultado obtido no teste de Mann- Whitney (valor-p 0,015), o desempenho das empresas pode sofrer impacto, visto que, de acordo com a literatura (BARBOSA; LOURI, 2005; GRASSENI, 2010) o número de funcionários pode influenciar o desempenho.

\subsection{CARACTERIZAÇÃO DO PERFIL DO RESPONDENTE}

Os resultados expostos nas Tabelas 6 e 7 possuem como finalidade responder ao segundo objetivo específico que consiste em descrever o perfil dos entrevistados das MPEs inseridas em redes horizontais de cooperação e dos entrevistados das MPEs que atuam independente de qualquer relação interorganizacional e verificar se há diferença entre os respectivos perfis.

No que concerne ao perfil do respondente, os resultados expostos na Tabela 6 , indicam que quase a totalidade dos entrevistados são sócios ou proprietários do estabelecimento 
entrevistado, sendo $83,6 \%$ para as empresas cooperadas e $85,7 \%$ para as empresas não cooperadas. Também há prevalência de respondentes do sexo masculino em oposição ao sexo feminino, sendo as empresas cooperadas com $74,6 \%$ e $25,4 \%$, respectivamente e as não cooperadas com $76 \%$ e $24 \%$, respectivamente.

Para ambas as variáveis citadas, "função do respondente na empresa" e "sexo do respondente", aplicou-se o teste Qui-quadrado, obtendo um valor-p de 0,920 e 0,830, respectivamente. Portanto, é possível constatar que não há diferença significante entre as frequências esperadas, permitindo concluir que os grupos de empresas cooperadas e não cooperadas não se comportam de maneira distinta em relação às referidas variáveis.

Tabela 6: Perfil do respondente das empresas cooperadas e não cooperadas e resultados do teste Quiquadrado

\begin{tabular}{|c|c|c|c|c|c|c|}
\hline \multirow{2}{*}{\multicolumn{2}{|c|}{ Variável }} & \multicolumn{2}{|c|}{ Cooperada } & \multicolumn{2}{|c|}{ Não cooperada } & \multirow{2}{*}{$\begin{array}{c}\text { Qui- } \\
\text { Quadrado }\end{array}$} \\
\hline & & $\mathrm{N}$ & $\%$ & $\mathrm{n}$ & $\%$ & \\
\hline $\begin{array}{l}\text { Função do } \\
\text { respondente na } \\
\text { empresa } \\
\end{array}$ & $\begin{array}{c}\text { Sócio-proprietário } \\
\text { Gerente } \\
\text { Outras } \\
\end{array}$ & $\begin{array}{c}56 \\
8 \\
3 \\
\end{array}$ & $\begin{array}{c}83,6 \\
11,9 \\
4,5 \\
\end{array}$ & $\begin{array}{c}132 \\
16 \\
6 \\
\end{array}$ & $\begin{array}{c}85,7 \\
10,4 \\
3,9 \\
\end{array}$ & 0,920 \\
\hline Sexo do respondente & $\begin{array}{c}\text { Masculino } \\
\text { Feminino }\end{array}$ & $\begin{array}{l}50 \\
17 \\
\end{array}$ & $\begin{array}{l}74,6 \\
25,4 \\
\end{array}$ & $\begin{array}{c}117 \\
37 \\
\end{array}$ & $\begin{array}{l}76,0 \\
24,0\end{array}$ & 0,830 \\
\hline Idade do respondente & $\begin{array}{c}25 \text { a } 35 \\
36 \text { a } 45 \\
>45\end{array}$ & $\begin{array}{l}19 \\
28 \\
20 \\
\end{array}$ & $\begin{array}{l}28,4 \\
41,8 \\
29,9 \\
\end{array}$ & $\begin{array}{l}43 \\
63 \\
48 \\
\end{array}$ & $\begin{array}{l}27,9 \\
40,9 \\
31,2 \\
\end{array}$ & 0,981 \\
\hline $\begin{array}{l}\text { Escolaridade do } \\
\text { respondente }\end{array}$ & $\begin{array}{l}\text { Ensino Médio } \\
\text { Graduação } \\
\text { Pós-graduação }\end{array}$ & $\begin{array}{c}22 \\
36 \\
9 \\
\end{array}$ & $\begin{array}{l}32,8 \\
53,8 \\
13,4 \\
\end{array}$ & $\begin{array}{l}46 \\
87 \\
21 \\
\end{array}$ & $\begin{array}{l}29,9 \\
56,5 \\
13,6 \\
\end{array}$ & 0,905 \\
\hline $\begin{array}{l}\text { Tempo de atuação do } \\
\text { respondente no } \\
\text { segmento da empresa }\end{array}$ & $\begin{array}{l}1 \text { a } 10 \\
11 \text { a } 20 \\
>20\end{array}$ & $\begin{array}{l}24 \\
29 \\
14 \\
\end{array}$ & $\begin{array}{l}35,8 \\
43,3 \\
20,9 \\
\end{array}$ & $\begin{array}{l}85 \\
52 \\
17 \\
\end{array}$ & $\begin{array}{l}55,2 \\
33,8 \\
11,0 \\
\end{array}$ & $0,019 *$ \\
\hline $\begin{array}{l}\text { Tempo de atuação do } \\
\text { respondente na } \\
\text { empresa }\end{array}$ & $\begin{array}{l}1 \text { a } 5 \\
6 \text { a } 10 \\
>10\end{array}$ & $\begin{array}{l}21 \\
22 \\
24 \\
\end{array}$ & $\begin{array}{l}31,3 \\
32,8 \\
35,8 \\
\end{array}$ & $\begin{array}{l}60 \\
50 \\
44 \\
\end{array}$ & $\begin{array}{l}39,0 \\
32,5 \\
28,6 \\
\end{array}$ & 0,463 \\
\hline $\begin{array}{l}\text { Tempo de atuação do } \\
\text { respondente no cargo } \\
\text { atual }\end{array}$ & $\begin{array}{l}1 \text { a } 5 \\
6 \text { a } 10 \\
>10\end{array}$ & $\begin{array}{l}24 \\
21 \\
22 \\
\end{array}$ & $\begin{array}{l}35,8 \\
31,3 \\
32,8 \\
\end{array}$ & $\begin{array}{l}71 \\
47 \\
36 \\
\end{array}$ & $\begin{array}{l}46,1 \\
30,5 \\
23,4 \\
\end{array}$ & 0,253 \\
\hline
\end{tabular}

* significante a $5 \%$.

Fonte: Elaborado pela autora, baseado nos dados coletados (2015)

Em relação à idade dos entrevistados, verificou-se que a maior parte possui entre $36 \mathrm{e}$ 45 anos, sendo 41,8\% dos respondentes das empresas cooperadas e 40,9\% dos respondentes das empresas não cooperadas. O teste Qui-quadrado efetuado para esta variável também indica que não há diferença significante entre as frequências esperadas, ou seja, os grupos de empresas cooperadas e não cooperadas não possuem diferenças significantes em relação idade dos respondentes, visto que o valor-p obtido é de 0,981 . 
No que diz respeito ao grau de escolaridade dos respondentes, encontrou-se uma quantidade representativa de indivíduos das empresas cooperadas e não cooperadas, que possuem titulação de graduação, sendo 53,8\% e 56,5\%, respectivamente e um discreto percentual de entrevistados pós-graduados, 13,4\% e 13,6\%, respectivamente. Assim como nas variáveis já apresentadas, o teste Qui-quadrado não apresentou diferença significante entre as frequências esperadas, uma vez que o valor-p obtido foi igual a 0,905, indicando que os grupos de empresas cooperadas e não cooperadas não possuem diferenças significantes para a escolaridade do respondente.

Entre as empresas cooperadas predominou a quantidade de respondentes que possuem algum curso de graduação (53,8\%), como por exemplo, administração, ciências contábeis, turismo, medicina veterinária, entre outros. Assim como nas empresas não cooperadas que também possui em sua maioria curso de graduação (56,5\%), uma diferença superior de apenas $2,7 \%$ para o percentual obtido nas cooperadas. Entre as formações citadas estão administração, ciências contábeis, direito, nutrição, gastronomia, educação física, entre outros.

Concernente ao tempo de atuação do respondente no segmento da empresa observa-se que a maioria dos entrevistados de empresas cooperadas (43,3\%) possui de 11 a 20 anos de experiência no ramo em que atuam. Tal período pode ser considerado razoável, visto que quanto maior o tempo de exercício do indivíduo na mesma atividade, maior sua experiência e consequentemente melhor é a contribuição que ele poderá fornecer à empresa (BERTRAND; HALLOCK, 2001).

Em contrapartida, a maior parte dos entrevistados das empresas não cooperadas $(55,2 \%)$ possui entre 1 a 10 anos de experiência no ramo em que atuam. O valor-p obtido no teste Qui-quadrado para esta variável $(0,019)$, indica que existe diferença significante entre as frequências, por conseguinte, as empresas cooperadas e não cooperadas divergem em relação ao tempo de atuação do respondente no segmento da empresa.

No tocante ao tempo de atuação do respondente na empresa, os resultados indicam que a maior parte dos entrevistados das cooperadas trabalha na empresa a mais de 10 anos $(68,6 \%)$, ao passo que a maioria dos respondentes das não cooperadas atua na empresa a menos de 10 anos (71,5\%). Apesar das diferenças, o teste Qui-quadrado apresentou valor -p igual a 0,463 para esta variável, estabelecendo que as empresas cooperadas e não cooperadas não divergem em relação ao tempo de atuação do respondente na empresa, uma vez que, não há diferença significante entre as frequências. 
Em relação ao tempo de atuação do respondente no cargo atual, verificou-se que tanto as empresas cooperadas quanto as empresas não cooperadas possuem em sua maioria respondentes com menos de 10 anos no cargo em que ocupam, sendo 67,1\% e 76,6\%, respectivamente. O teste qui-quadrado apresentou valor-p igual a 0,253 evidenciando que não há associação significante entre os grupos de empresas cooperadas e não cooperadas em relação ao tempo de atuação do respondente no cargo atual.

$\mathrm{Na}$ Tabela 7, são apresentadas as medidas descritivas das variáveis intervalares do perfil do respondente, bem como evidencia os resultados decorrentes do teste de MannWhtiney, utilizado para identificar se existe diferença estatística significante entre os grupos de empresas cooperadas e não cooperadas.

Tabela 7: Medidas descritivas do perfil do respondente e seus testes de Mann-Whitney para comparação dos grupos de empresas cooperadas e não cooperadas

\begin{tabular}{|c|c|c|c|c|c|c|c|}
\hline Variável & Empresa & Média & $\begin{array}{l}\text { Desvio } \\
\text { Padrão }\end{array}$ & Mediana & Mínimo & Máximo & $\begin{array}{l}\text { p - valor } \\
\text { (Mann- } \\
\text { Whitney) }\end{array}$ \\
\hline \multirow[b]{2}{*}{ Idade do respondente } & Cooperada & 41,25 & 8,24 & 40,00 & 28 & 58 & \multirow[b]{2}{*}{0,698} \\
\hline & $\begin{array}{c}\text { Não } \\
\text { Cooperada }\end{array}$ & 41,69 & 8,2 & 41,50 & 28 & 61 & \\
\hline \multirow{2}{*}{$\begin{array}{l}\text { Tempo de atuação do } \\
\text { respondente no } \\
\text { segmento da empresa }\end{array}$} & Cooperada & 14,54 & 8,12 & 13,00 & 1 & 32 & \multirow[b]{2}{*}{$0,009 *$} \\
\hline & $\begin{array}{c}\text { Não } \\
\text { Cooperada }\end{array}$ & 11,61 & 7,73 & 10,00 & 1 & 30 & \\
\hline \multirow{2}{*}{$\begin{array}{l}\text { Tempo de atuação do } \\
\text { respondente na } \\
\text { empresa }\end{array}$} & Cooperada & 9,22 & 6,04 & 9,00 & 1 & 27 & \multirow[b]{2}{*}{0,279} \\
\hline & $\begin{array}{c}\text { Não } \\
\text { Cooperada }\end{array}$ & 8,32 & 5,8 & 7,00 & 1 & 28 & \\
\hline \multirow{2}{*}{$\begin{array}{l}\text { Tempo de atuação do } \\
\text { respondente no cargo } \\
\text { atual }\end{array}$} & Cooperada & 8,91 & 6,04 & 9,00 & 1 & 27 & \multirow[b]{2}{*}{0,105} \\
\hline & $\begin{array}{c}\text { Não } \\
\text { Cooperada }\end{array}$ & 7,45 & 6,00 & 5,32 & 1 & 20 & \\
\hline
\end{tabular}

* significante a $5 \%$

Fonte: Elaborado pela autora, baseado nos dados coletados (2015)

A média e mediana da idade dos respondentes de empresas cooperadas corresponde a 41,25 e 40 anos, respectivamente, ao passo que os entrevistados das não cooperadas possuem 41,69 e 41,50, respectivamente. Com isso, verifica-se que tanto a média, como a mediana são resultados semelhantes para os grupos de empresas cooperadas e não cooperadas, no que se refere à idade dos respondentes. Aplicou-se também o teste de normalidade KolmogorovSmirnov para esta variável, resultando no valor-p de 0,013, indicando que a variável não possui distribuição normal o que permite a aplicação do teste Mann-Whitney. Este teste, por sua vez, resultou no p-valor de 0,698 , indicando que não há diferença estatística significante na idade mediana da empresa entre o grupo de empresas cooperadas e o grupo de empresas não cooperadas. 
O tempo de atuação do respondente no segmento da empresa apresenta mediana equivalente a 13,00 para empresas cooperadas e 10,00 para empresas não cooperadas, ao passo que resultou na média de 14,54 e 11,61 para as cooperadas e não cooperadas, respectivamente, uma diferença superior das cooperadas de apenas 2,7\% para o percentual obtido das cooperadas. O teste de Kolmogorov-Smirnov apresentou valor-p menor que 0,001, possibilitando a realização do teste Mann-Whitney. Este, por sua vez, resultou no valor-p de 0,009, permitindo concluir que há diferença estatística significante no tempo de atuação do respondente no segmento da empresa entre o grupo de empresas cooperadas e o grupo de empresas não cooperadas.

As variáveis "tempo de atuação do respondente na empresa" e "tempo de atuação do respondente no cargo atual" apresentaram para as empresas cooperadas, médias equivalentes a 9,22 e 8,91, respectivamente e ambas medianas correspondem a 9,00. Apresentando médias menores, as empresas não cooperadas obtiveram os seguintes resultados para as variáveis "tempo de atuação do respondente na empresa" e "tempo de atuação do respondente no cargo atual", 8,32 e 7,45, respectivamente, enquanto que as medianas apresentaram valores discrepantes, 7,00 e 5,32, respectivamente. Tais dados revelam que alguns respondentes estão na empresa por determinado tempo e ocuparam funções diferentes ao longo desse período.

Os testes de Kolmogorov-Smirnov para ambas as variáveis resultaram no valor-p menor que 0,001, possibilitando a aplicação do teste de Mann-Whitney. Este, por sua vez, resultou o valor-p de 0,279 e 0,105 para "tempo de atuação do respondente na empresa" e "tempo de atuação do respondente no cargo atual”, respectivamente. Demonstrando que não há diferença estatística significante entre o grupo de empresas cooperadas e o grupo de empresas não cooperadas, para as duas últimas variáveis apresentadas.

Conforme mencionada anteriormente, quanto maior o tempo de exercício do indivíduo na mesma atividade, maior sua experiência e consequentemente melhor é a contribuição que ele poderá fornecer à empresa (BERTRAND; HALLOCK, 2001). O mesmo raciocínio pode ser empregado também com relação ao tempo de atuação do respondente na empresa e ao tempo de atuação do respondente no cargo atual. É importante identificar o tempo de atuação, principalmente no cargo, tendo em vista que quando um trabalhador é submetido a uma atividade por diversas vezes há melhora no desempenho, ocasionada talvez pela familiaridade e habilidade desenvolvida com a realização das funções (DAR-EL, 2000).

Em resumo, os respondentes das empresas cooperadas são em sua maioria do sexo masculino (74,6\%), possuem idade entre 36 e 45 anos (41,8\%), sendo a idade média 41 anos. Quanto aos respondentes das empresas não cooperadas, verificou-se que, assim como as 
cooperadas, o sexo masculino predomina (76\%) e a maioria também possuem idade entre 36 e 45 anos (40,9\%), obtendo uma média de 42 anos.

No que diz respeito às empresas cooperadas, em relação ao tempo de atuação do respondente no segmento da empresa estas obtiveram média de 12 anos, 3 anos a menos que as cooperadas. 39\% dos respondentes está trabalhando na empresa entre 1 e 5 anos. Quanto ao tempo de atuação do respondente no cargo atual, pode-se constatar que $46 \%$ possui entre 1 e 5 anos de experiência e média de 7 anos. É possível identificar que o tempo médio de atuação na empresa é aproximado ao tempo médio de atuação no cargo, indicando que ao adentrar na organização, os respondentes já ocuparam de imediato suas posições atuais.

Os testes Qui-quadrado revelaram que dentre todas as características observadas, apenas o tempo de atuação do respondente no segmento da empresa possui diferença significante entre as frequências observadas e as esperadas. Nesse caso, os respondentes das empresas cooperadas possuem tempo de experiência no ramo da empresa superior ao respondente da não cooperada.

As características sexo do respondente, idade do respondente, escolaridade do respondente, tempo de atuação do respondente na empresa e tempo de atuação do respondente no cargo atual, possuem diferenças muito pequenas entre as frequências observadas e as esperadas, próximas a zero, portanto pode-se concluir que os dois grupos comportam-se de maneira semelhante quanto às referidas características.

Os testes de Mann-Whitney também revelaram que as medianas obtidas para a característica "tempo de atuação do respondente no segmento da empresa" possui diferença significante entre os grupos analisados, ao passo que para as outras características também não apresentaram diferença significante entre as medianas.

\subsection{DESEMPENHO DAS EMPRESAS}

O presente tópico tem como objetivo identificar o desempenho organizacional das empresas cooperadas e não cooperadas investigadas a partir das dimensões: satisfação dos clientes, satisfação dos funcionários, crescimento e lucratividade. Estas dimensões foram mensuradas a partir da percepção do respondente comparando a situação da sua empresa com a dos seus concorrentes mais próximos. Adicionalmente, as duas últimas dimensões, consideradas medidas financeiras (crescimento da empresa e a lucratividade da empresa) 
foram mensuradas, também, a partir da percepção do respondente comparando a situação da empresa com o ano anterior, ou seja, comparando o ano de 2014 com o ano de 2013.

Uma vez mensurados os desempenhos sobre as perspectivas apresentadas, são efetuados os testes de Mann-Whtiney, com a finalidade de responder ao objetivo geral da pesquisa de verificar se as MPEs inseridas em redes horizontais de cooperação apresentam desempenho organizacional superior àquelas que atuam independente de qualquer relação interorganizacional.

\subsubsection{Desempenho organizacional em comparação aos concorrentes}

Inicialmente investigou-se a percepção dos entrevistados a respeito da satisfação dos clientes, satisfação dos funcionários, crescimento e lucratividade da empresa em relação aos concorrentes do setor.

Tabela 8: Medida de fidedignidade Alfa de Cronbach para o desempenho organizacional em comparação aos concorrentes correspondente a cada item ausente e para todos os itens com seu intervalo de confiança

\begin{tabular}{|c|c|c|}
\hline $\begin{array}{c}\text { Medida de } \\
\text { Desempenho }\end{array}$ & Variável & $\begin{array}{c}\text { Alfa de } \\
\text { Cronbach }\end{array}$ \\
\hline \multirow{5}{*}{$\begin{array}{l}\text { Satisfação dos } \\
\text { clientes }\end{array}$} & Valor agregado para o cliente & 0,82 \\
\hline & Reclamações de clientes & 0,85 \\
\hline & Fidelidade dos clientes & 0,83 \\
\hline & Retenção de novos clientes & 0,82 \\
\hline & Satisfação geral dos clientes & 0,82 \\
\hline \multirow{6}{*}{$\begin{array}{l}\text { Satisfação dos } \\
\text { funcionários }\end{array}$} & Rotatividade dos funcionários & 0,84 \\
\hline & Investimento no desenvolvimento e treinamento dos funcionários & 0,82 \\
\hline & Política de remuneração e benefícios & 0,82 \\
\hline & Plano de carreira & 0,82 \\
\hline & Clima organizacional & 0,83 \\
\hline & Satisfação geral dos funcionários & 0,82 \\
\hline \multirow{5}{*}{$\begin{array}{l}\text { Crescimento da } \\
\text { empresa }\end{array}$} & Crescimento da participação de mercado & 0,82 \\
\hline & Crescimento do ativo total & 0,81 \\
\hline & Crescimento do faturamento & 0,82 \\
\hline & Crescimento do lucro líquido & 0,82 \\
\hline & Crescimento do número de funcionários & 0,82 \\
\hline \multirow{2}{*}{$\begin{array}{l}\text { Lucratividade da } \\
\text { empresa }\end{array}$} & Retorno sobre o capital investido & 0,82 \\
\hline & Lucro líquido sobre as vendas & 0,82 \\
\hline \multicolumn{2}{|r|}{ Alfa de Cronbach } & 0,83 \\
\hline \multicolumn{2}{|r|}{ Intervalo com $95 \%$ de confiança para Alfa de Cronbach } & 0,79 a 0,86 \\
\hline
\end{tabular}

Fonte: Elaborado pela autora (2015) 
Para esse bloco de perguntas, realizaram-se os testes de validação de escalas no intuito de verificar a consistência interna do mesmo. Os resultados referentes ao bloco de perguntas “Desempenho organizacional em comparação aos concorrentes" estão evidenciados na Tabela 8.

Observa-se que todas as questões relativas ao bloco desempenho organizacional em comparação aos concorrentes obtiveram Alfa de Cronbach superior a 0,70, sendo este o valor mínimo aceitável para o Alfa. Dessa forma, pode-se concluir pela confirmação da consistência interna do referido bloco de perguntas.

Desempenho medido pela satisfação dos clientes em comparação aos concorrentes

Quando questionados sobre a satisfação dos clientes em relação aos seus concorrentes, os respondentes indicaram seus níveis de satisfação em relação às variáveis: valor agregado para o cliente, reclamações de clientes, fidelidade dos clientes, retenção de novos clientes e satisfação geral dos clientes, os quais estão explícitos na Tabela 9.

Tabela 9: Medidas descritivas do desempenho organizacional medido pela satisfação dos clientes em comparação aos concorrentes e respectivos testes de Mann-Whitney para comparação das empresas cooperadas e não cooperadas

\begin{tabular}{|c|c|c|c|c|c|c|c|}
\hline \multirow[b]{2}{*}{ Variável } & \multicolumn{3}{|c|}{ Cooperada } & \multicolumn{3}{|c|}{ Não Cooperada } & \multirow{2}{*}{$\begin{array}{c}\text { Valor - p } \\
\text { (Mann- } \\
\text { Whitney) }\end{array}$} \\
\hline & Média & $\begin{array}{c}\text { Desvio- } \\
\text { padrão }\end{array}$ & $\begin{array}{c}\% \% \\
\text { Empresas } \\
\text { Satisfeitas }\end{array}$ & Média & $\begin{array}{c}\text { Desvio- } \\
\text { padrão }\end{array}$ & $\begin{array}{c}\% \\
\text { Empresas } \\
\text { Satisfeitas }\end{array}$ & \\
\hline $\begin{array}{l}\text { Valor agregado para } 0 \\
\text { cliente }\end{array}$ & 3,88 & 0,64 & 73,1 & 3,66 & 0,54 & 62,3 & $0,016^{*}$ \\
\hline Reclamações de clientes & 3,97 & 0,63 & 82,1 & 3,72 & 0,70 & 65,5 & $0,010^{*}$ \\
\hline Fidelidade dos clientes & 4,09 & 0,65 & 83,6 & 3,82 & 0,69 & 65,6 & $0,006^{*}$ \\
\hline Retenção de novos clientes & 3,94 & 0,95 & 63,8 & 3,56 & 0,91 & 40,9 & $0,004 *$ \\
\hline Satisfação geral dos clientes & 4,04 & 0,68 & 85,1 & 3,95 & 0,75 & 77,3 & 0,410 \\
\hline Escore & 19,93 & 1,83 & 53,8 & 18,71 & 2,02 & 35,0 & $<0,001 *$ \\
\hline
\end{tabular}

* significante a 5\%.

Fonte: Elaborado pela autora, baseado nos dados coletados (2015)

Os resultados indicam que a maior parte dos respondentes está realizada ao indicar níveis médios de satisfação em relação aos seus clientes quando comparados aos seus concorrentes. No entanto, as empresas cooperadas apresentam maior nível de satisfação com clientes em todas as variáveis observadas, conforme médias apresentadas. Considerando a utilização da escala tipo Likert (1 a 5), considerou-se para o cálculo do percentual das empresas satisfeitas, o percentual das respostas 4 e 5 obtidas, ao passo que 1 e 2 
correspondem as empresas com baixa satisfeitas e 3 equivale às empresas com satisfação média. No Gráfico 1 é possível contemplar os percentuais de satisfação das empresas investigadas para cada categoria (baixa satisfação, média satisfação e alta satisfação), nas cinco dimensões avaliadas.

Os dados do Gráfico 1 evidenciam que de acordo com a percepção do gestor, as empresas cooperadas possuem desempenho alto em comparação aos seus concorrentes nas variáveis analisadas, ao passo que as empresas não cooperadas apresentam desempenho médio em relação aos seus concorrentes nas variáveis analisadas.

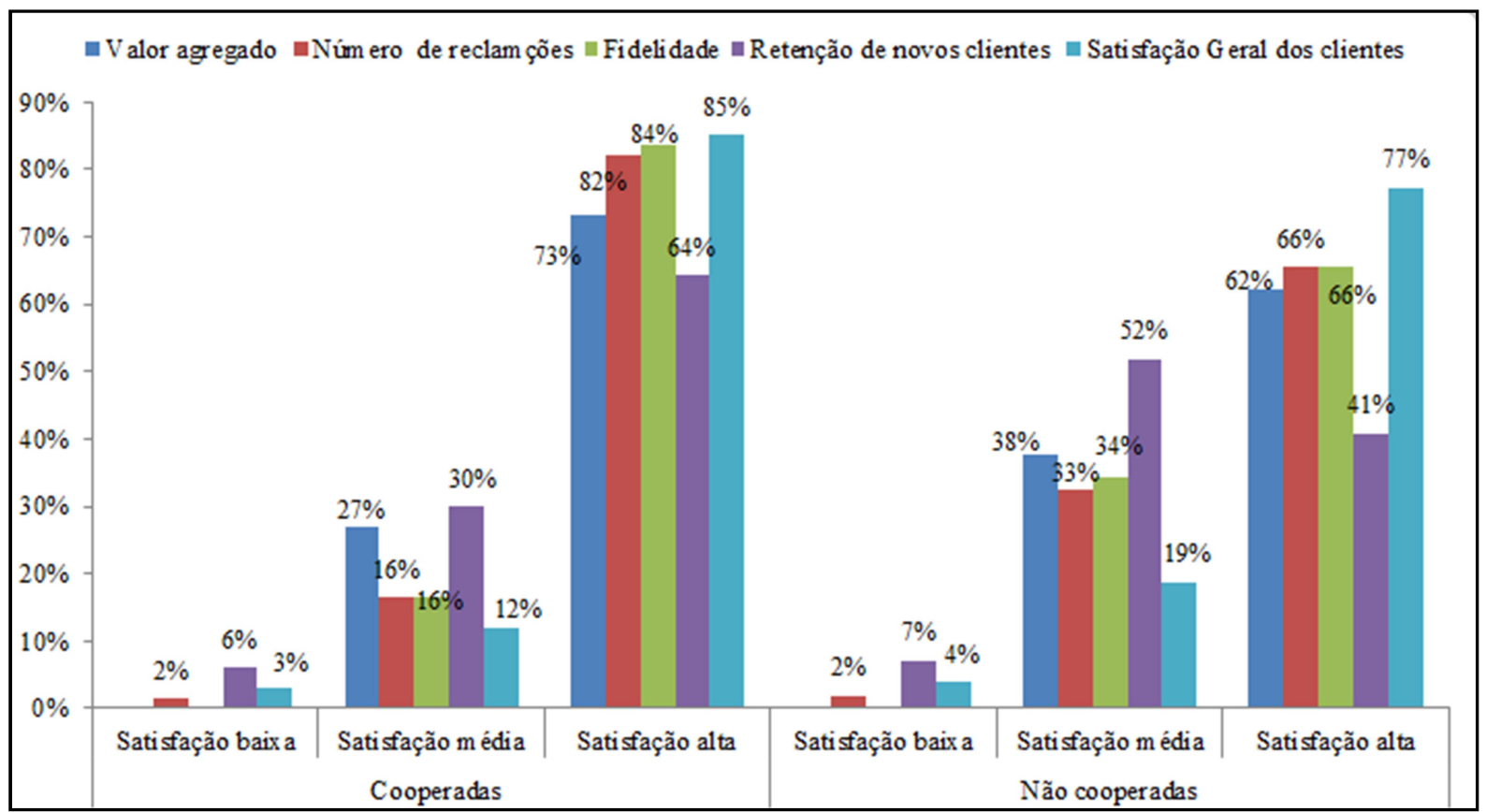

Gráfico 1: Desempenho medido pela satisfação dos clientes das empresas cooperadas e não cooperadas em comparação aos concorrentes e seus níveis de satisfação

No que diz respeito aos testes de Mann-Whitney, evidenciados na Tabela 9 constata-se que para todas as dimensões avaliadas, com exceção da satisfação geral dos clientes, há diferença estatística significante entre o grupo de empresas cooperadas e o grupo de empresas não cooperadas. Além disso, o escore de todas as variáveis também evidencia que os grupos são significativamente divergentes $(\mathrm{p}<0,001)$, conduzindo à conclusão de que em relação à satisfação dos clientes as empresas cooperadas apresentam desempenho superior quando comparadas às não cooperadas.

Tal diferença pode ser explicada inicialmente tendo em vista que intrinsecamente as empresas cooperadas sentem-se mais satisfeitas apenas pelo fato de serem cooperadas. Em um segundo momento, pode-se destacar também que após a inserção da empresa em uma rede de 
cooperação mudanças notórias são observadas pelos seus clientes, a exemplo de: alterações no layout da empresa, estabelecimento de uma nova marca, com uma nova faixada da empresa, fardamento padronizado dos funcionários, treinamento dos funcionários e consequentemente melhor atendimento aos clientes por parte desses.

Além disso, pode-se elencar também a variedade de produtos de marcas diferentes disponíveis aos clientes, gerando maior satisfação a estes, isso porque as empresas inseridas em redes efetuam compras em conjunto e devido ao alto volume podem barganhar preços e consequentemente disponibilizar maior variedade de mercadorias.

Outro fator que pode ter contribuído para o percentual de satisfação obtido entre as empresas cooperadas diz respeito à troca de informações entre os participantes da rede que agregam valor às organizações por meio de ativos intangíveis, que por sua vez, desenvolvem estratégias de fidelização e retenção de clientes.

Portanto, quanto ao desempenho medido pela satisfação dos clientes, conclui-se que as MPEs inseridas em redes horizontais de cooperação apresentam, na percepção do gestor, desempenho organizacional superior àquelas que atuam independente de qualquer relação interorganizacional.

\section{Desempenho medido pela satisfação dos funcionários em comparação aos concorrentes}

Uma vez questionados sobre a satisfação dos funcionários em comparação aos seus concorrentes, os entrevistados apresentaram sua percepção acerca de seis dimensões: rotatividade dos funcionários, investimento no desenvolvimento e treinamento de funcionários, política de remuneração e benefícios, plano de carreira, clima organizacional e satisfação geral dos funcionários. Os resultados das referidas dimensões estão evidenciados na Tabela 10.

A partir dos resultados obtidos, verifica-se que os entrevistados, de um modo geral apresentam níveis médios de satisfação em relação aos seus funcionários quando comparados aos seus concorrentes. Isto porque para todas as dimensões, observa-se média superior a 3,00, tanto nas empresas cooperadas, quanto nas empresas não cooperadas. Contudo, observa-se nas empresas cooperadas uma média superior a 4,00, no que diz respeito à "rotatividade dos funcionários", "clima organizacional" e "satisfação geral dos funcionários", indicando que os respondentes possuem satisfação alta em relação a estas dimensões. 
Tabela 10: Medidas descritivas do desempenho organizacional medido pela satisfação dos funcionários em comparação aos concorrentes e respectivos testes de Mann-Whitney para comparação das empresas cooperadas e não cooperadas

\begin{tabular}{|c|c|c|c|c|c|c|c|}
\hline \multirow[b]{2}{*}{ Variável } & \multicolumn{3}{|c|}{ Cooperada } & \multicolumn{3}{|c|}{ Não Cooperada } & \multirow{2}{*}{$\begin{array}{c}\text { Valor - p } \\
\text { (Mann- } \\
\text { Whitney) }\end{array}$} \\
\hline & Média & $\begin{array}{l}\text { Desvio- } \\
\text { padrão }\end{array}$ & $\begin{array}{c}\% \\
\text { Empresas } \\
\text { Satisfeitas } \\
\end{array}$ & Média & $\begin{array}{l}\text { Desvio- } \\
\text { padrão }\end{array}$ & $\begin{array}{c}\% \% \\
\text { Empresas } \\
\text { Satisfeitas } \\
\end{array}$ & \\
\hline Rotatividade de funcionários & 4,21 & 1,04 & 80,6 & 3,94 & 1,16 & 66,2 & 0,104 \\
\hline Capacitação de funcionários & 3,84 & 0,91 & 59,7 & 3,35 & 0,73 & 27,3 & $<0,001^{*}$ \\
\hline $\begin{array}{l}\text { Política de remuneração e } \\
\text { benefícios }\end{array}$ & 3,69 & 0,74 & 55,2 & 3,47 & 0,73 & 39,6 & $0,038^{*}$ \\
\hline Plano de carreira & 3,43 & 0,93 & 43,3 & 3,12 & 0,71 & 22,1 & $0,012^{*}$ \\
\hline Clima organizacional & 4,03 & 0,72 & 82,1 & 3,79 & 0,69 & 68,8 & $0,012^{*}$ \\
\hline $\begin{array}{l}\text { Satisfação geral dos } \\
\text { funcionários }\end{array}$ & 4,10 & 0,65 & 83,6 & 3,81 & 0,67 & 66,2 & $0,003 *$ \\
\hline Escore & 23,30 & 3,06 & 92,5 & 21,47 & 3,08 & 79,9 & $<0,001 *$ \\
\hline
\end{tabular}

* significante a $5 \%$.

Fonte: Elaborado pela autora, baseado nos dados coletados (2015)

É possível contemplar no Gráfico 2 os percentuais de satisfação (satisfação baixa, satisfação média e satisfação alta) das empresas cooperadas e não cooperadas, nas cinco dimensões avaliadas.

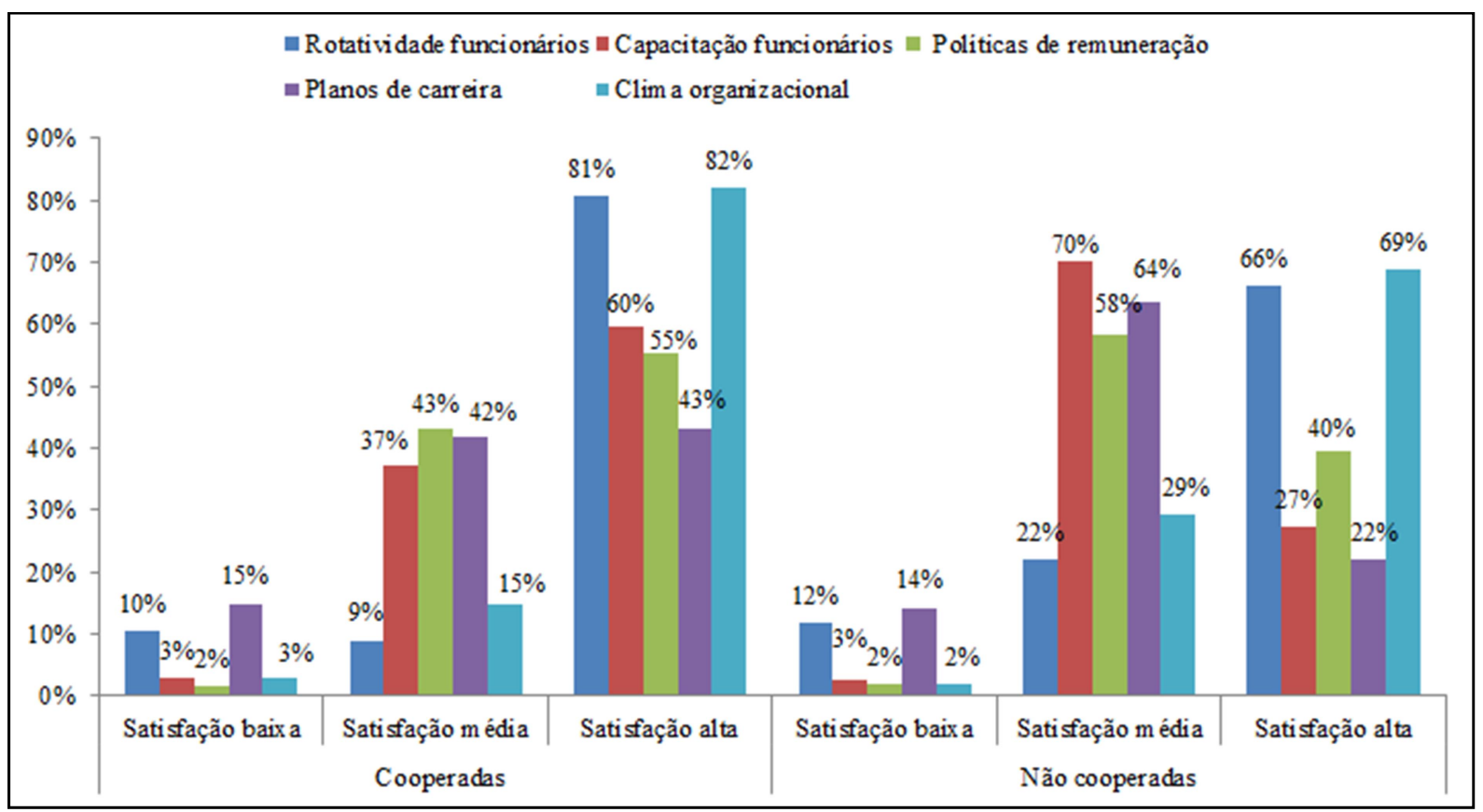

Gráfico 2: Desempenho medido pela satisfação dos funcionários das empresas cooperadas e não cooperadas em comparação aos concorrentes e seus níveis de satisfação

Em relação à "capacitação de funcionários", "políticas de remuneração" e "planos de carreira", os respondentes das empresas não cooperadas apresentam percentuais de níveis 
médios de satisfação superior aos percentuais de alta satisfação. Ao passo que os entrevistados das empresas cooperadas exibem percentuais de alta satisfação superior que os percentuais médios de satisfação em todas as dimensões avaliadas.

No que diz respeito ao teste Mann-Whitney, cujos resultados estão evidenciados na Tabela 10, verifica-se que com exceção da "rotatividade dos funcionários", todas as variáveis apresentam diferença significante entre os grupos de empresas cooperadas e não cooperadas. A dimensão "investimento no desenvolvimento dos funcionários", por exemplo, apresentou um valor-p menor que 0,001 . Isso pode ser justificado pelo fato de que para as empresas inseridas em redes de cooperação pode haver uma maior facilidade em organizar treinamentos de funcionários, em contrapartida para as empresas não cooperadas, os custos para esse tipo de atividade acabam sendo elevados para que a mesma assuma todas as despesas individualmente.

O escore geral obtido para todas as dimensões relativas à satisfação dos funcionários (valor-p inferior a 0,001) indica que os grupos de empresas cooperadas e não cooperadas possuem diferença significante, sendo as empresas cooperadas aquelas que apresentam desempenho organizacional superior às empresas não cooperadas.

Os resultados obtidos podem ser justificados inicialmente haja vista que as empresas cooperadas possuem menor quantidade de funcionários do que as não cooperadas, e por consequência os laços desenvolvidos entre empregado e patrão podem ser mais estreitos.

Aliado a isso, os membros da rede geralmente reúnem todos os seus funcionários e realizam capacitações periódicas. Assim como ocorre na compra de mercadorias, por ser um número elevado de pessoas, os gestores também conseguem negociar melhor seus custos com empresas de capacitação, facilitando a ocorrência mais frequente de treinamentos.

Por conseguinte, no que diz respeito à satisfação dos funcionários as MPEs inseridas em redes horizontais de cooperação apresentam desempenho organizacional superior àquelas que atuam independente de qualquer relação interorganizacional, na percepção do gestor.

\section{Desempenho medido pelo crescimento da empresa em comparação aos concorrentes}

Com o objetivo de mensurar o desempenho financeiro, questionou-se aos entrevistados acerca do crescimento da empresa em relação aos seus concorrentes. Os respondentes indicaram seus níveis de satisfação em relação a cinco dimensões, a saber: "crescimento da participação no mercado", "crescimento do ativo total", "crescimento do 
faturamento", "crescimento do lucro líquido" e "crescimento do número de funcionários". Os resultados encontram-se delineados na Tabela 11.

É possível observar a partir dos resultados expostos que as médias obtidas para todas as dimensões, independente da empresa ser ou não cooperada é superior a 3,00, indicando que os entrevistados apresentam níveis médios de satisfação em relação ao crescimento da empresa quando comparado aos concorrentes. As médias das empresas cooperadas são superiores às médias das empresas não cooperadas em todas as dimensões, em especial no "crescimento da participação no mercado". O Gráfico 3 expõe os percentuais de satisfação (satisfação baixa, satisfação média e satisfação alta) das empresas cooperadas e não cooperadas, nas cinco dimensões avaliadas.

Tabela 11: Medidas descritivas do desempenho organizacional medido pelo crescimento da empresa em comparação aos concorrentes e respectivos testes de Mann-Whitney para comparação das empresas cooperadas e não cooperadas

\begin{tabular}{|c|c|c|c|c|c|c|c|}
\hline \multirow[b]{2}{*}{ Variável } & \multicolumn{3}{|c|}{ Cooperada } & \multicolumn{3}{|c|}{ Não Cooperada } & \multirow{2}{*}{$\begin{array}{c}\text { Valor - p } \\
\text { (Mann- } \\
\text { Whitney) }\end{array}$} \\
\hline & Média & $\begin{array}{c}\text { Desvio- } \\
\text { padrão }\end{array}$ & $\begin{array}{c}\% \\
\text { Empresas } \\
\text { Satisfeitas }\end{array}$ & Média & $\begin{array}{l}\text { Desvio- } \\
\text { padrão }\end{array}$ & $\begin{array}{c}\% \\
\text { Empresas } \\
\text { Satisfeitas }\end{array}$ & \\
\hline $\begin{array}{l}\text { Crescimento da participação } \\
\text { no mercado }\end{array}$ & 4,00 & 0,65 & 79,1 & 3,51 & 0,62 & 50,6 & $<0,001 *$ \\
\hline Crescimento do ativo total & 3,90 & 0,59 & 77,6 & 3,60 & 0,61 & 60,4 & $0,002 *$ \\
\hline Crescimento do faturamento & 3,91 & 0,57 & 79,1 & 3,67 & 0,59 & 66,9 & $0,009 *$ \\
\hline Crescimento do lucro líquido & 3,88 & 0,66 & 71,6 & 3,56 & 0,62 & 55,8 & $0,002 *$ \\
\hline $\begin{array}{l}\text { Crescimento do número de } \\
\text { funcionários }\end{array}$ & 3,67 & 0,82 & 56,7 & 3,17 & 0,68 & 29,2 & $<0,001^{*}$ \\
\hline Escore & 19,36 & $\mathbf{1 , 8 5}$ & 43,3 & 17,51 & 2,40 & $\mathbf{1 7 , 5}$ & $<\mathbf{0 , 0 0 1 *}$ \\
\hline
\end{tabular}

* significante a $5 \%$.

Fonte: Elaborado pela autora, baseado nos dados coletados (2015)

Observa-se que, assim como no desempenho medido pela satisfação dos clientes e no desempenho medido pela satisfação dos funcionários, as empresas cooperadas apresentam percentuais de níveis altos de satisfação superior aos percentuais de satisfação média quando o desempenho é medido pelo crescimento da empresa em relação aos concorrentes. Em contraponto, as empresas não cooperadas apresentaram níveis de satisfação média superior aos níveis de satisfação alta. Ambos os grupos de empresas, cooperadas e não cooperadas, apresentaram percentual irrelevante de satisfação baixa.

Com a finalidade de verificar se há diferença significante entre os grupos das empresas cooperadas e empresas não cooperadas, no que diz respeito ao desempenho medido pelo crescimento das empresas em relação aos seus concorrentes, aplicou-se o teste de MannWhitney para cada dimensão, conforme dados da Tabela 11. 




Gráfico 3: Desempenho medido pelo crescimento nas empresas cooperadas e não cooperadas em comparação aos concorrentes e seus níveis de satisfação

Constata-se que em relação a todas as dimensões observadas os grupos apresentam diferença significativa, com destaque para "crescimento da participação no mercado" e “crescimento do número de funcionários”, ambas com valor-p menor que 0,001. Dessa forma, pode-se entender que o desempenho das cooperadas é superior ao das não cooperadas no que tange ao crescimento das empresas em comparação aos seus concorrentes, de acordo com a percepção dos gestores.

\section{Desempenho medido pela lucratividade da empresa em comparação aos concorrentes}

Ainda com a intenção de mensurar o desempenho financeiro das empresas investigadas, indagou-se sobre a lucratividade da empresa em comparação aos seus concorrentes. Os respondentes indicaram seus níveis de satisfação em relação a duas dimensões, a saber: "retorno sobre o capital investido" e "lucro líquido sobre as vendas", os quais os resultados estão elencados na Tabela 12.

Consoante a Tabela 12, verifica-se que as empresas tanto as cooperadas como as não cooperadas, apresentaram médias acima de 3,00 indicando níveis médios de satisfação. No Gráfico 4, é possível analisar os percentuais de satisfação (satisfação baixa, satisfação média e satisfação alta) das empresas cooperadas e não cooperadas, nas dimensões "retorno sobre o capital investido" e "lucro líquido sobre as vendas". 
Tabela 12: Medidas descritivas do desempenho organizacional medido pela lucratividade da empresa em comparação aos concorrentes e respectivos testes de Mann-Whitney para comparação das empresas cooperadas e não cooperadas

\begin{tabular}{|c|c|c|c|c|c|c|c|}
\hline \multirow[b]{2}{*}{ Variável } & \multicolumn{3}{|c|}{ Cooperada } & \multicolumn{3}{|c|}{ Não Cooperada } & \multirow{2}{*}{$\begin{array}{c}\text { Valor - p } \\
\text { (Mann- } \\
\text { Whitney) }\end{array}$} \\
\hline & Média & $\begin{array}{l}\text { Desvio- } \\
\text { padrão }\end{array}$ & $\begin{array}{c}\% \\
\text { Empresas } \\
\text { Satisfeitas } \\
\end{array}$ & Média & $\begin{array}{l}\text { Desvio- } \\
\text { padrão }\end{array}$ & $\begin{array}{c}\% \\
\text { Empresas } \\
\text { Satisfeitas } \\
\end{array}$ & \\
\hline $\begin{array}{l}\text { Retorno sobre o capital } \\
\text { investido }\end{array}$ & 3,79 & 0,69 & 64,2 & 3,46 & 0,57 & 44,8 & $0,001^{*}$ \\
\hline $\begin{array}{l}\text { Lucro líquido sobre as } \\
\text { vendas }\end{array}$ & 3,81 & 0,74 & 67,2 & 3,39 & 0,61 & 39,0 & $<0,001^{*}$ \\
\hline Escore & 7,60 & 1,55 & $\mathbf{5 3 , 7}$ & 6,85 & 0,99 & 25,3 & $<0,001 *$ \\
\hline
\end{tabular}

* significante a $5 \%$.

Fonte: Elaborado pela autora, baseado nos dados coletados (2015)

É possível contemplar no Gráfico 4 que enquanto as empresas cooperadas apresentam percentuais mais acentuados na dimensão "satisfação alta", os percentuais das empresas não cooperadas estão mais concentrados na "satisfação média". Além disso, verifica-se que há baixa satisfação (3\%) das cooperadas em relação ao lucro líquido sobre as vendas e baixa satisfação (1\%) das não cooperadas quando diz respeito ao retorno sobre o capital investido.

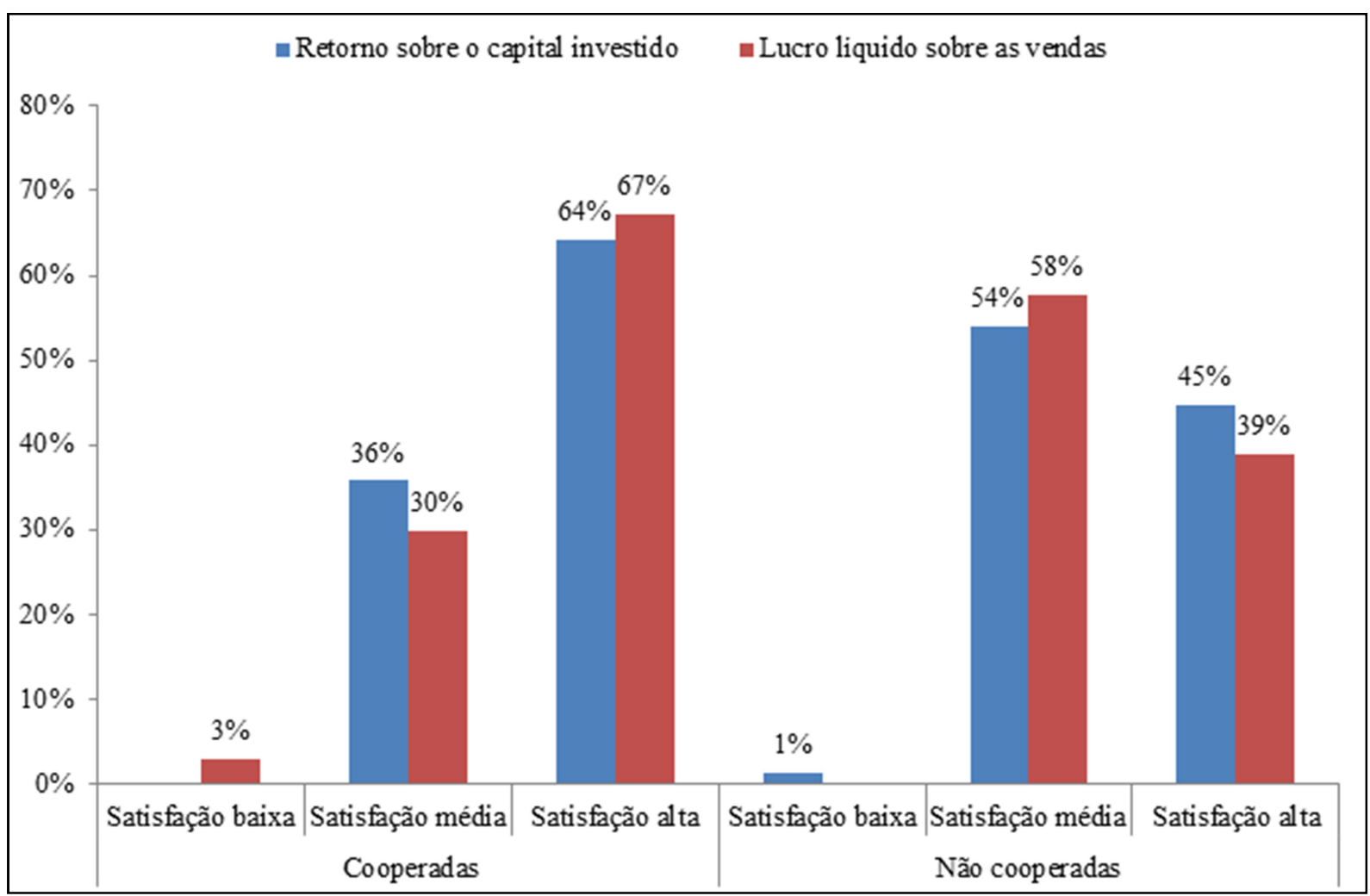

Gráfico 4: Desempenho medido pela lucratividade nas empresas cooperadas e não cooperadas em comparação aos concorrentes e seus níveis de satisfação

O teste de Man-Whitney também foi aplicado para a lucratividade das empresas, objetivando identificar se os grupos das cooperadas e não cooperadas possuem diferença, no 
que diz respeito à referida lucratividade, conforme dados demonstrados na Tabela 12. É notória a diferença entre os grupos, tendo em vista o valor-p obtido para cada variável, 0,001 e menor que 0,001 para retorno sobre o capital investido e lucro líquido sobre as vendas, respectivamente. Portanto, é possível afirmar que o desempenho das empresas cooperadas é superior ao das empresas não cooperadas no que diz respeito à lucratividade em comparação com os concorrentes, na percepção do gestor.

Assim sendo, verificou-se que quanto ao desempenho medido pela satisfação dos clientes, satisfação dos fornecedores, crescimento da empresa e lucratividade da empresa em comparação aos concorrentes constatou-se que as empresas inseridas em redes de cooperação apresentam desempenho superior às não cooperadas, de acordo com a percepção do gestor.

\subsubsection{Desempenho em comparação ao ano anterior}

Com a finalidade de complementar a mensuração do desempenho organizacional, verificou-se também a satisfação dos entrevistados a respeito das medidas de desempenho financeiro em relação ao ano anterior. Assim como para o bloco de perguntas referentes ao "desempenho organizacional em comparação aos concorrentes", realizaram-se os testes de validação de escalas no intuito de verificar a consistência interna para o bloco de perguntas “desempenho organizacional em comparação ao ano anterior". Os resultados, por sua vez, estão elencados na Tabela 13.

Tabela 13: Medida de fidedignidade Alfa de Cronbach para o desempenho organizacional em comparação ao ano anterior correspondente a cada item ausente e para todos os itens com seu intervalo de confiança

\begin{tabular}{c|l|c}
\hline $\begin{array}{c}\text { Medida de } \\
\text { Desempenho }\end{array}$ & \multicolumn{1}{|c|}{ Variável } & $\begin{array}{c}\text { Alfa de } \\
\text { Cronbach }\end{array}$ \\
\hline $\begin{array}{c}\text { Crescimento da } \\
\text { empresa }\end{array}$ & Crescimento da participação de mercado & 0,86 \\
\hline $\begin{array}{c}\text { Lucratividade da } \\
\text { empresa }\end{array}$ & Crescimento do lucro líquido & 0,86 \\
\hline \multicolumn{2}{c|}{ Alfa de Cronbach } & 0,83 \\
\hline \multicolumn{2}{c|}{ Lucro líquido sobre as vendas } & 0,81 \\
\hline
\end{tabular}

Fonte: Elaborado pela autora (2015)

Verifica-se que todas as variáveis, presentes neste bloco de perguntas apresentam Alfa de Cronbach superior a 0,70 , sendo este o valor mínimo aceitável para o Alfa, portanto os 
resultados atestam pela consistência do bloco de perguntas referente ao desempenho organizacional em comparação ao ano anterior.

Desempenho medido pelo crescimento da empresa em comparação ao ano anterior

Quando questionados sobre o desempenho medido pelo crescimento da empresa em comparação ao ano anterior, os entrevistados opinaram a respeito da sua satisfação com o crescimento da participação de mercado e crescimento do lucro líquido. Os resultados das médias obtidas para as empresas cooperadas e não cooperadas, estão evidenciadas na Tabela 14.

Tabela 14: Medidas descritivas do desempenho organizacional medido pelo crescimento da empresa em comparação ano anterior e respectivos testes de Mann-Whitney para comparação das empresas cooperadas e não cooperadas

\begin{tabular}{|c|c|c|c|c|c|c|c|}
\hline \multirow[b]{2}{*}{ Variável } & \multicolumn{3}{|c|}{ Cooperada } & \multicolumn{3}{|c|}{ Não Cooperada } & \multirow{2}{*}{$\begin{array}{c}\text { Valor - p } \\
\text { (Mann- } \\
\text { Whitney) }\end{array}$} \\
\hline & Média & $\begin{array}{c}\text { Desvio- } \\
\text { padrão }\end{array}$ & $\begin{array}{c}\% \% \\
\text { Empresas } \\
\text { Satisfeitas }\end{array}$ & Média & $\begin{array}{c}\text { Desvio- } \\
\text { padrão }\end{array}$ & $\begin{array}{c}\% \\
\text { Empresas } \\
\text { Satisfeitas }\end{array}$ & \\
\hline $\begin{array}{l}\text { Crescimento da participação } \\
\text { de mercado }\end{array}$ & 3,33 & 0,568 & 29,0 & 3,20 & 0,42 & 19,4 & 0,115 \\
\hline Crescimento do lucro líquido & 3,35 & 0,626 & 27,0 & 3,19 & 0,39 & 19,5 & 0,144 \\
\hline Escore & 6,68 & $\mathbf{1 , 1 0}$ & 27,0 & 6,40 & $\mathbf{0 , 7 3}$ & 14,3 & 0,154 \\
\hline
\end{tabular}

Fonte: Elaborado pela autora, baseado nos dados coletados (2015)

Observa-se que as médias obtidas estão em torno de 3,00 para as empresas cooperadas, bem como para as empresas não cooperadas. Vale salientar que há diferença mínima entre as médias dos grupos, com pequena vantagem para as empresas cooperadas. Tal resultado corrobora com aqueles obtidos na comparação do crescimento da empresa em relação aos concorrentes.

Os percentuais de satisfação (satisfação baixa, satisfação média e satisfação alta) das empresas cooperadas e não cooperadas, nas dimensões "crescimento da participação de mercado" e "crescimento do lucro líquido" quando comparadas ao ano anterior estão evidenciados no Gráfico 5.

A partir do Gráfico 5 é possível observar um percentual superior das empresas não cooperadas concentradas no nível de satisfação média, tanto em relação ao "crescimento da participação no mercado" e no "crescimento do lucro líquido". As empresas cooperadas comportam-se da mesma forma, entretanto com um percentual um pouco superior de "satisfação alta" quando comparadas as não cooperadas. 


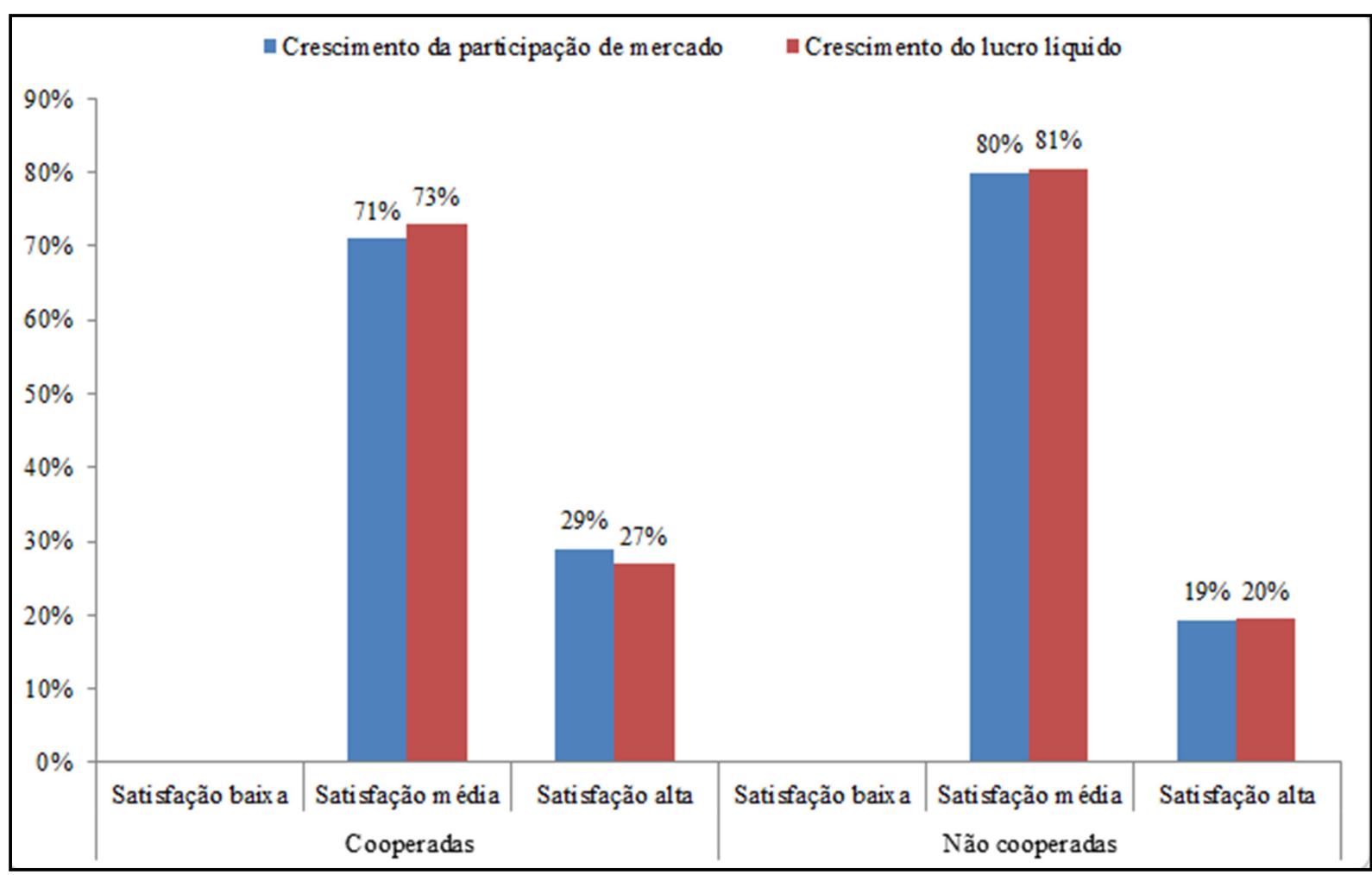

Gráfico 5: Desempenho medido pelo crescimento das empresas cooperadas e não cooperadas em comparação ao ano anterior e seus níveis de satisfação

Com a finalidade de verificar se os grupos das empresas cooperadas e não cooperadas possuem diferença no que diz respeito ao crescimento da empresa em comparação ao ano anterior, aplicou-se o teste de Man-Whitney. Os resultados obtidos, demonstrados na Tabela 14, permitem aceitar a hipótese nula de igualdade entre os grupos, visto que o valor-p para o crescimento da participação no mercado e o crescimento do lucro líquido são 0,115 e 0,144 , respectivamente. Dessa forma, no que tange ao crescimento da empresa em comparação ao ano anterior o desempenho das empresas cooperadas não é superior ao das empresas não cooperadas.

Desempenho medido pela lucratividade da empresa em comparação ao ano anterior

Os respondentes também foram indagados sobre a lucratividade da empresa em comparação ao ano anterior, sendo uma medida financeira adicional para complementação da análise. Os resultados obtidos, dispostos na Tabela 15, demonstram que os respondentes também apresentam níveis médios de satisfação, sendo as empresas cooperadas aquelas que possuem um percentual discretamente superior às empresas não cooperadas, conforme percepção do gestor. 
Tabela 15: Medidas descritivas do desempenho organizacional medido pela lucratividade da empresa em comparação ano anterior e respectivos testes de Mann-Whitney para comparação das empresas cooperadas e não cooperadas

\begin{tabular}{l|c|c|c|c|c|c|c}
\hline \multirow{2}{*}{ Variável } & \multicolumn{3}{|c|}{ Cooperada } & \multicolumn{3}{c|}{ Não Cooperada } & \multicolumn{2}{c}{\begin{tabular}{c} 
Valor - p \\
(Mann- \\
\cline { 2 - 7 }
\end{tabular}} & Média & $\begin{array}{c}\text { Desvio- } \\
\text { padrão }\end{array}$ & $\begin{array}{c}\text { Empresas } \\
\text { Satisfeitas }\end{array}$ & Média & $\begin{array}{c}\text { Desvio- } \\
\text { padrão }\end{array}$ & $\begin{array}{c}\text { Empresas } \\
\text { Satisfeitas }\end{array}$ & $\begin{array}{c}\text { Whitney) } \\
\begin{array}{l}\text { Retorno sobre o capital } \\
\text { investido }\end{array}\end{array}$ & 3,95 & 0,682 & 81,0 & 3,65 & 0,75 & 66,8 & 0,006 \\
$\begin{array}{l}\text { Lucro líquido sobre as } \\
\text { vendas }\end{array}$ & 3,92 & 0,655 & 81,0 & 3,63 & 0,72 & 66,9 & 0,007 \\
\hline \multicolumn{1}{c|}{ Escore } & $\mathbf{7 , 8 7}$ & $\mathbf{1 , 2 4}$ & $\mathbf{7 9 , 0}$ & $\mathbf{7 , 2 8}$ & $\mathbf{1 , 4 3}$ & $\mathbf{6 6 , 8}$ & $\mathbf{0 , 0 0 9}$ \\
\hline
\end{tabular}

Fonte: Elaborado pela autora, baseado nos dados coletados (2015)

O Gráfico 6 elucida os percentuais de satisfação (satisfação baixa, satisfação média e satisfação alta) das empresas cooperadas e não cooperadas, nas dimensões "retorno sobre o capital investido" e "lucro líquido sobre as vendas" quando comparados ao ano anterior.

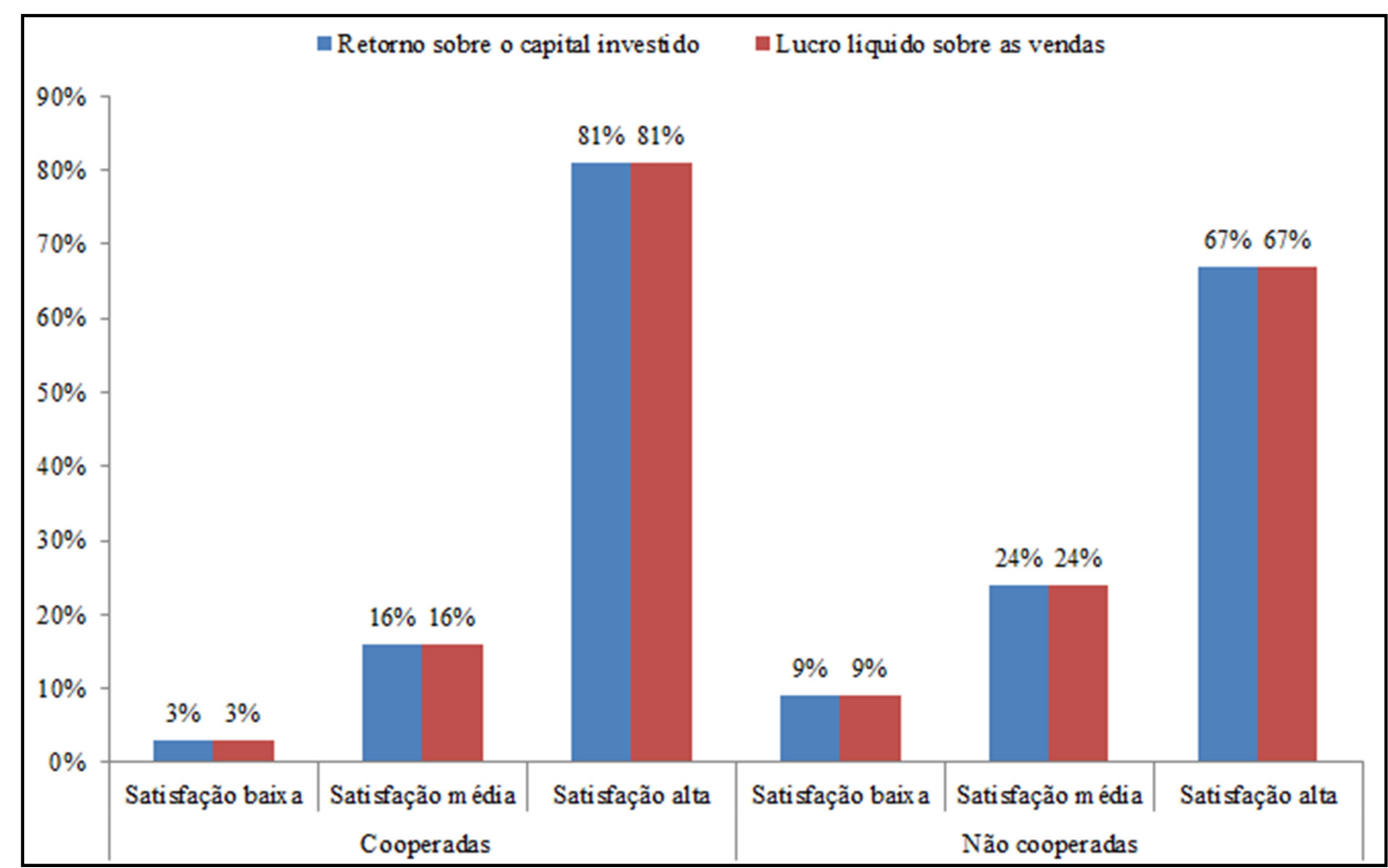

Gráfico 6: Desempenho medido pela lucratividade das empresas cooperadas e não cooperadas em comparação ao ano anterior e seus níveis de satisfação

Pode-se observar que os percentuais obtidos tanto para as empresas cooperadas quanto para as empresas não cooperadas coincidem para ambas as dimensões, em seus níveis de satisfação baixa, satisfação média e satisfação alta. 
No que diz respeito ao teste de Man-Whitney, os resultados obtidos, demonstrados na Tabela 15, permitem aceitar a hipótese nula de igualdade entre os grupos, visto que o valor-p para o retorno sobre o capital investido e o lucro líquido sobre as vendas são 0,006 e 0,007, respectivamente. Portanto, no que concerne à lucratividade da empresa em comparação ao ano anterior o desempenho das empresas cooperadas não é superior ao das empresas não cooperadas.

É importante destacar que quando indagados sobre as mesmas medidas financeiras, crescimento e lucratividade da MPE, porém, em relação aos concorrentes, o desempenho das empresas cooperadas mostra-se superior ao das empresas não cooperadas. Isso pode ser justificado, pelo fato do gestor estar mais satisfeito em relação ao seu concorrente apenas por estar inserido em uma rede e considerar que seu "rival" está em "desvantagem" por não ser participante da referida rede. Tendo em vista que na análise das mesmas medidas “crescimento e lucratividade da MPE”, porém em relação ao ano anterior, não é identificado um percentual satisfatório por parte das empresas cooperadas.

\subsubsection{Desempenho geral}

Adicionalmente, foi acrescentada ao instrumento uma pergunta complementar, em que os entrevistados demonstram sua satisfação com o desempenho da empresa de modo abrangente e global, considerando todos os aspectos e dinâmica geral da empresa em confronto com seus concorrentes e com o desempenho geral apresentado no ano anterior.

Em relação aos testes de consistência efetuados para este bloco de perguntas, os quais os resultados encontram-se disponíveis na Tabela 16, pode-se atestar pela confiabilidade de das questões referentes ao bloco "desempenho geral", tendo em vista que foi obtido um alfa de 0,79 .

Tabela 16: Medida de fidedignidade Alfa de Cronbach para o desempenho organizacional geral correspondente a cada item ausente e para todos os itens com seu intervalo de confiança

\begin{tabular}{c|c}
\hline Variável & Alfa de Cronbach \\
\hline $\begin{array}{c}\text { Desempenho geral comparado aos concorrentes } \\
\text { Desempenho geral comparado ao ano anterior }\end{array}$ & - \\
\hline Alfa de Cronbach & 0,79 \\
\hline Intervalo com 95\% de confiança para Alfa de Cronbach & 0,72 a 0,84 \\
\hline
\end{tabular}


No que diz respeito aos resultados obtidos a partir dos questionamentos efetuados é possível contemplar na Tabela 17 que as empresas cooperadas e não cooperadas apresentaram médias acima de 3,00. No entanto, as médias obtidas pelas empresas cooperadas são superiores as médias alcançadas pelas empresas não cooperadas, tanto para a variável “desempenho geral comparado aos concorrentes", quanto para variável "desempenho geral comparado ao ano anterior".

Tabela 17: Medidas descritivas do desempenho organizacional medido pelo desempenho geral e respectivos testes de Mann-Whitney para comparação das empresas cooperadas e não cooperadas

\begin{tabular}{|c|c|c|c|c|c|c|c|}
\hline \multirow[b]{2}{*}{ Variável } & \multicolumn{3}{|c|}{ Cooperada } & \multicolumn{3}{|c|}{ Não Cooperada } & \multirow{2}{*}{$\begin{array}{c}\text { Valor - p } \\
\text { (Mann- } \\
\text { Whitney) }\end{array}$} \\
\hline & Média & $\begin{array}{c}\text { Desvio- } \\
\text { padrão }\end{array}$ & $\begin{array}{c}\% \\
\text { Empresas } \\
\text { Satisfeitas }\end{array}$ & Média & $\begin{array}{c}\text { Desvio- } \\
\text { padrão }\end{array}$ & $\begin{array}{c}\% \\
\text { Empresas } \\
\text { Satisfeitas }\end{array}$ & \\
\hline $\begin{array}{l}\text { Desempenho Geral } \\
\text { comparado aos concorrentes }\end{array}$ & 3,87 & 0,74 & 74,7 & 3,68 & 0,84 & 62,3 & 0,124 \\
\hline $\begin{array}{l}\text { Desempenho Geral } \\
\text { comparado ao ano anterior }\end{array}$ & 3,83 & 0,73 & 70,0 & 3,57 & 0,77 & 57,8 & 0,35 \\
\hline Escore & 7,46 & 1,62 & 58,3 & 7,25 & 1,54 & 50,6 & 0,183 \\
\hline
\end{tabular}

Fonte: Elaborado pela autora, baseado nos dados coletados (2015)

Os percentuais de satisfação obtidos (satisfação baixa, satisfação média e satisfação alta) das empresas cooperadas e não cooperadas (Gráfico 7) demonstram que as empresas cooperadas possuem maior número de respondentes satisfeitos, visto que $74 \%$ e $70 \%$ corresponde ao percentual de satisfação alta para "desempenho geral comparado com os concorrentes" e "desempenho geral comparado ao ano anterior", respectivamente. 


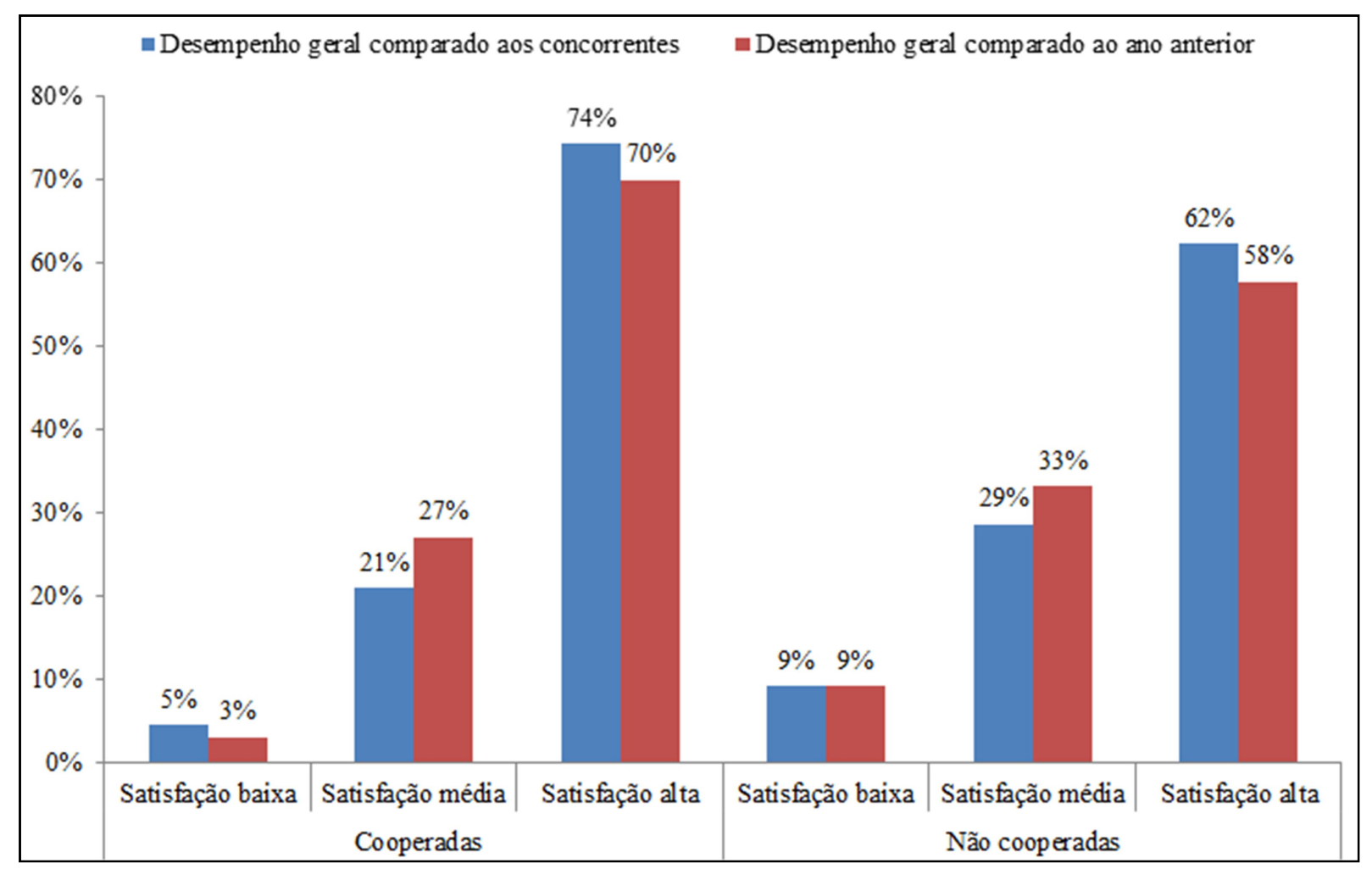

Gráfico 7: Desempenho medido pelo desempenho geral das empresas cooperadas e não cooperadas em comparação ao ano anterior e seus níveis de satisfação

Em contrapartida, os respondentes das empresas não cooperadas foram mais cautelosos ao manterem maior equilíbrio, quando comparadas às empresas cooperadas, entre os percentuais de satisfação alta e satisfação média.

Apesar das diferenças nos percentuais obtidos entre os grupos, o teste de ManWhitney, evidenciado na Tabela 17, apresentou valor-p de 0,124 e valor-p de 0,35, consentindo aceitar a hipótese nula de igualdade entre os grupos. Dessa forma, entende-se que o desempenho geral das empresas cooperadas não é superior ao das empresas não cooperadas.

\subsubsection{Escore para todas as medidas de Desempenho Organizacional}

A partir dos escores obtidos para cada medida de desempenho foi calculado o escore total utilizado como indicador de desempenho total, conforme Tabela 18.

Tabela 18: Desempenho organizacional medido pelo escore de todos os escores das medidas descritivas e respectivos testes de Mann-Whitney para comparação das empresas cooperadas e não cooperadas

\begin{tabular}{c|c|c|c|c|c}
\hline \multirow{2}{*}{ Variável } & \multicolumn{2}{|c|}{ Cooperada } & \multicolumn{2}{c|}{ Não Cooperada } & \multirow{2}{*}{ Valor - p } \\
\cline { 2 - 5 } & Média & Desvio-padrão & Média & Desvio-padrão & (Mann-Whitney) \\
\hline Escore Desempenho TOTAL & 91,33 & 8,08 & 85,47 & 6,99 & $<0,001^{*}$ \\
\hline
\end{tabular}

* significante a $5 \%$.

Fonte: Elaborado pela autora, baseado nos dados coletados (2015) 
De acordo com os resultados obtidos para o teste de Mann-Whitney, pode-se considerar que há diferença significante entre os grupos de empresas cooperadas e não cooperadas (valor-p menor que 0,001). Adicionalmente pode-se verificar que as empresas cooperadas apresentaram melhor média de desempenho $(91,33)$ quando comparadas às empresas não cooperadas $(85,47)$. Dessa forma, é possível concluir que as MPEs inseridas em redes horizontais de cooperação apresentam desempenho organizacional superior àquelas que atuam independente de qualquer relação interorganizacional.

Tal resultado corrobora com a pesquisa de Wegner, Callado e Agnes (2014), em que as redes apresentaram em algumas dimensões, desempenho superior ao daquelas que não estão inseridas em nenhuma rede. Por sua vez, Andrade e Hoffmann (2010), afirmaram em sua pesquisa que as MPEs dificilmente alcançariam um melhor desempenho agindo isoladamente e destacam a relevância das Redes de Cooperação.

De fato, a presente pesquisa também indica o papel de destaque das redes de cooperação, tendo em vista que em várias dimensões de medição de desempenho, estas apresentaram vantagem sobre as MPEs não cooperadas. Além disso, quanto ao desempenho total (gerado pela soma de todos os escores de todos os desempenhos) também se manteve superior às empresas não cooperadas.

Por fim, a Tabela 19 apresenta as medidas de fidedignidade Alfa de Cronbach para o instrumento como um todo.

Tabela 19: Medida de fidedignidade Alfa de Cronbach para o instrumento da pesquisa a cada item ausente e para todos os itens com seu intervalo de confiança

\begin{tabular}{l|c|c}
\hline \multicolumn{1}{c|}{ Dimensão } & $\begin{array}{c}\text { Alfa de } \\
\text { Cronbach }\end{array}$ & $\begin{array}{c}\text { Intervalo com 95\% de } \\
\text { confiança para Alfa }\end{array}$ \\
\hline Desempenho organizacional em comparação aos concorrentes & 0,83 & 0,79 a 0,86 \\
Desempenho organizacional em comparação ao ano anterior & 0,88 & 0,85 a 0,90 \\
Desempenho organizacional geral & 0,79 & 0,72 a 0,84 \\
\hline Global & 0,81 & 0,77 a 0,84 \\
\hline
\end{tabular}

Fonte: Elaborado pela autora (2015)

Considerando todos os respondentes, obteve-se um alfa no valor de 0,81 , uma vez que 0,70 é considerado o valor mínimo para atestar a fidedignidade do instrumento, verifica-se que a consistência interna do instrumento está adequada e evidencia que o instrumento apresenta medidas fidedignas quanto à mensuração do desempenho. 


\section{CAPÍTULO V: CONSIDERAÇÕES FINAIS}

O presente capítulo concentra-se em expor as principais conclusões da pesquisa. Além disso, o objetivo desta seção consiste em apresentar as implicações teóricas e gerenciais do estudo, as limitações da pesquisa e sugestões para pesquisas futuras.

\subsection{IMPLICAÇÕES TEÓRICAS E GERENCIAIS}

A motivação propulsora para a realização da presente pesquisa deveu-se à escassez de estudos sobre as redes de cooperação no Nordeste brasileiro. Ademais, nos últimos anos tem havido um crescimento cada vez maior de empresas que se inserem em redes de cooperação no nordeste, em especial na Paraíba, fato este que motiva à produção de pesquisas.

Dessa maneira, pelas razões já elencadas na introdução deste trabalho, buscou-se verificar se as MPEs inseridas em redes horizontais de cooperação apresentam desempenho organizacional superior àquelas que atuam independente de qualquer relação interorganizacional.

De acordo com os resultados obtidos na pesquisa empírica, foi possível verificar que de acordo com a percepção dos gestores, as empresas inseridas em redes de cooperação apresentam desempenho organizacional superior àquelas que não estão inseridas em nenhuma relação interorganizacional. Uma possível explicação para tal fato deve-se à força que as redes vêm adquirindo por representar uma alternativa das MPEs concorrerem em âmbito global.

Além disso, características peculiares das empresas inseridas em redes, como por exemplo, a troca de conhecimento entre os membros, gerando informações coletivas e individuais contribui para auxiliar no compartilhamento de conhecimentos em decorrência dos laços firmados entre os participantes da rede, de modo que a aprendizagem mútua é amplificada.

As redes de cooperação têm contribuído para gerar renda, favorecendo a criação de empregos e capacitando as empresas, através de cursos, oficinas, encontros, palestras, entre outros. Além do que, o sucesso destas deve-se também ao auxílio de instituições que atuam como elemento propulsor da formação da rede, realizando o devido acompanhamento, estabelecendo acordos e fornecendo informações aos membros da rede. No que diz respeito às MPEs que não estão inseridas em nenhum tipo de relação interorganizacional, percebe-se que apesar destas encontrarem-se, em sua maioria, consolidadas no mercado, tendo em vista o 
tempo de empresa médio, estas apresentam na percepção do gestor um desempenho inferior às empresas cooperadas. Sugere-se, portanto, que haja uma busca por parte das mesmas por capacitação, troca de conhecimento com outras empresas, treinamento de funcionários, utilização das ferramentas de gestão para uma melhor gerência e consequentemente melhor desempenho.

Adicionalmente, vale ressaltar que este trabalho investiu na pesquisa em MPEs, sendo estas uma peça fundamental no âmbito socioeconômico do país. Deve-se considerar a contribuição destas para a geração de empregos e redução da pobreza, tornando-as reconhecida por governos de vários países em desenvolvimento.

\subsection{LIMITAÇÕES E SUGESTÕES PARA PESQUISAS FUTURAS}

Sabe-se que devido às restrições de recursos e tempo a pesquisa apresenta alguns pormenores, como é característico de todo e qualquer estudo.

Um dos fatores limitantes da presente pesquisa, por sua vez, está associado ao fato da amostra ser não-probabilística e por conseguinte, torna-se impossível generalizar os resultados. Outro fator limitante diz respeito à avaliação do desempenho, visto que este foi medido pela satisfação do respondente a respeito de determinadas dimensões de desempenho. Entende-se que este tipo de mensuração pode sofrer interferências emocionais do respondente, conquanto, a medição do desempenho nas MPEs permanece sendo um desafio para a academia.

Para futuras pesquisas, sugere-se aumentar a amostra de empresas a fim de desenvolver maior confiabilidade nos resultados apresentados, bem como análises por meio de outras metodologias. Além disso, estudos comparativos podem ser realizados em diferentes contextos em que as redes de cooperação estão inseridas.

Adicionalmente, almeja-se que o presente estudo possa contribuir de alguma forma para o desenvolvimento das MPEs sejam estas participantes ou não de redes de cooperação. Além disso, espera-se que este assunto possa ser amplamente difundido para que mais MPEs possam considerar como sendo uma estratégia de sobrevivência a sua inserção em uma rede de cooperação.

Espera-se também que os resultados obtidos no presente estudo possam subsidiar informações cientificas relevantes (e comparativas) ainda escassas na literatura sobre redes de cooperação empresarial, e assim contribuir para o desenvolvimento e elucidação de outras pesquisas. 


\section{REFERÊNCIAS}

ACS, Z. J.; MORCK, R. K.; YEUNG, B. Entrepreneurship, globalization, and public policy. Journal of International Management, n. 7, p. 235-251, 2001.

AGUIAR, M. M. S.; IPIRANGA, A. S. R.; MACHADO, D. de Q.; MATOS, L. B. de S. Cooperação Interorganizacional no Setor Moveleiro: Um estudo de caso à luz da análise de redes sociais. REDES, Santa Cruz do Sul, v. 19, n 3, p. 196 - 214, set.- dez., 2014.

ALVES, J. N.; BALSAN, L. A. G.; BAZZO, P. S.; LUBECK, R. M.; GROHMANN, M. Z. Redes de Cooperação de Pequenas e Médias Empresas: Os Fatores Competitivos Aplicados em uma Rede de Imobiliárias. Gestão e Regionalidade, v. 26, n. 78, p. 18-35, set.- dez., 2010 .

AMATO NETO, J. Redes de cooperação produtiva e clusters regionais: oportunidades para as pequenas e médias empresas. São Paulo: Atlas, 2000.

ANDRADE, M. A. R.; HOFFMANN, V. E. Redes interorganizacionais: um estudo das pequenas e médias empresas no setor calçadista do Vale do Rio Tijucas. Revista de Administração e Inovação, v. 7, n. 2, p. 193-216, 2010.

ATHAYDE, M.; MARTINS, G. de A. O legado de McCelland e a educação empreendedora em contabilidade. In IV Congresso Anpcont, 2010, Natal - RN. Anais... IV Congresso ANPCONT, 2010.

ATOUBA, Y.; SHUMATE, M. Interorganizational networking patterns among development organizations. Journal of Communication, v. 60, n. 2, p. 293-317, 2010.

AVLONITIS, G. J.; SALAVOU, H. E. Entrepreneurial orientation of SMEs, product innovativeness, and performance. Journal of Business Research, v. 60, p. 566-575, 2007.

BAIRD, I. S.; LYLES, M. A.; JI, S.; WHARTON, R. Joint venture success: a Sino-U.S. perspective. International Studies of Management \& Organization, v. 20, n. 1, p. 125-134, 1990.

BALBINOT, Z.; MARQUES, R. A. Alianças estratégicas como condicionantes do desenvolvimento da capacidade tecnológica: o caso de cinco empresas do setor eletroeletrônico brasileiro. Revista de Administração Contemporânea, v. 13, n. 4, p. 604-625, 2009.

BALESTRIN, A. A dinâmica da complementaridade de conhecimentos no contexto das redes interorganizacionais. 2005. 214 f. Tese (Doutorado em Administração) - Programa de Pós-Graduação em Administração, Universidade Federal do Rio Grande do Sul, Porto Alegre, 2005. 
BALESTRIN, A.; VARGAS, L. M. A dimensão estratégica das redes horizontais de PMEs: teorizações e evidências. Revista de Administração Contemporânea, Curitiba, v. 8, Edição Especial, p. 203-228, 2004.

BALESTRIN, A.; VARGAS, L. M. Redes horizontais de cooperação como estrutura favorável ao desenvolvimento das PMEs. In: XXVII ENANPAD, 2003, São Paulo. Anais do XXVII Enanpad. São Paulo: Anpad, Setembro, 2003.

BALESTRIN, A.; VARGAS, L. M.; FAYARD, P. Knowledge creation in small-firm network. Journal of Knowledge Management, v. 12, n.2, p. 94-106, 2008.

BALESTRIN, A.; VARGAS, L. M.; FAYARD, P. O Efeito Rede nos Pólos de Inovação: Um Estudo Comparativo. Revista de Administração (FEA-USP), São Paulo, RAUSP, v. 40, n.2, p. 159-171, 2005.

BALESTRIN, A.; VERSCHOORE, J. Fatores Relevantes para o Estabelecimento de Redes de Cooperação entre Empresas do Rio Grande do Sul. Revista de Administração Contemporânea, Curitiba, v. 12, n. 4, p. 1043-1069, out.- dez., 2008.

BALESTRIN, A.; VERSCHOORE, J. Redes de Cooperação Empresarial: Estratégias de gestão na nova economia. Porto Alegre: Bookman, 2009.

BALESTRIN, A.; VERSCHOORE, J. Réplica - Redes são Redes ou Redes são Organizações? Revista de Administração Contemporânea, v. 18, p. 523-533, 2014.

BALESTRIN, A; VERSCHOORE, J. R.; REYS JR., E. O campo de estudos sobre redes de cooperação interorganizacional no Brasil. Revista de Administração Contemporânea, v. 14, n. 4, p. 458-477, 2010.

BARBOSA, N.; LOURI, H. Corporate performance: Does ownership matter? A comparison of foreign and domestic-owned firms in Greece and Portugal. Review of Industrial Organization, v. 27, n. 1, p. 73-102, 2005.

BENEVENE, P.; CORTINI, M. Interaction between structural capital and human capital in Italian NPOs: Leadership, organizational culture and human resource management. Journal of Intellectual Capital, v. 11, n. 2, p. 123-139. 2010.

BERGSMAN, S. Accounting for Small Businesses, Black Enterprise, v. 23, n. 4, Novembro, Nova Iorque, 1992.

BERTRAND, M.; HALLOCK, K. F.; The Gender Gap in Top Corporate Jobs. Industrial and Labor Relations Review, v. 55, n 1, out. 2001. 
BOFFI, S. A. N. O.; OLIVEIRA, E. A. A. Q.; CARNIELO, M. F.; SANTOS, V. S. Aplicação da metodologia do Balanced Scorecard no sistema de avaliação da qualidade de uma unidade estratégica de negócios. Revista Ibero-Americana de Estratégia, São Paulo, v.9, n.3, p.139173, set.- dez. 2010.

BORGATTI, S. P.; FOSTER, P. C. The network paradigm in organizational research: a review and typology. Journal of Management, v.29, n.6, p.991-1013, 2003.

BORTOLASO, I.; VERSCHOORE, J. R.; ANTUNES JÚNIOR, J. A. V. Estratégias Cooperativas: Avaliando a gestão da estratégia em redes de pequenas e médias empresas. Revista Brasileira de Gestão de Negócios, São Paulo, v. 14, n. 45, p. 419-437, out.- dez., 2012.

BOVET, D.; MARTHA; J. Redes de valor: aumente os lucros pelo uso da tecnologia da informação na cadeia de valor. Tradução Márcia Tadeu. São Paulo: Negócio Editora, 2001.

BRASS, D.; GALASKIEWICZ, J.; GREVE, H.; TSAI, W. Taking stock of networks and organizations: a multilevel perspective. Academy of Management Journal, v. 47 n. 6, p. 795-817, 2004.

BRATU, A. The necessity, organization and administration of management accounting within the SMEs. Manager Journal, v. 6, n. 1, p. 89-92. 2007.

BRIDGEWATER, S.; EGAN, C. International Marketing Relationships. New York: Palgrave, 2002.

BRONZO, M.; HONORIO, L. C. Estruturas reticulares em ambientes dinâmicos e competitivos: uma breve reflexão sobre a arquitetura e a coordenação das formas organizacionais em rede. In: I Encontro de Estudos em Estratégia, ANPAD, 2003, Curitiba. 3 ES/ANPAD, 2003.

BRUQUE, S.; MOYANO, J. Organizational determinants of information technology adoption and implementation in SMEs: the case of family and cooperative firms. Technovation, v. 27, n. 5, p. 241-253. 2007.

CABRELLI, F. L.; FERREIRA, A contabilidade gerencial como ferramenta no processo de tomada de decisão. Revista Científica Eletrônica de Ciências Contábeis, n. 9, 2007.

CAMPBELL, A.; GOOLD, M. The collaborative enterprise: why links across the corporation often fail and how to make them work. Reading: Perseus Books, 2000.

CÂNDIDO, G. A.; ABREU, A. F. Os conceitos de redes e as relações interorganizacionais: um estudo exploratório. In: Encontro Nacional da Associação Nacional dos Programas de Pós-Graduação em Administração, 24. 2000, Florianópolis. Anais. Florianópolis: ANPAD, 2000 . 
CARNEIRO, J. M. T.; SILVA, J. F.; ROCHA, A.; HEMAIS, C. A. Mensuração do Desempenho Organizacional: Questões Conceituais e Metodológicas. In: GUTIERREZ, Margarida; BERTRAND, Hélène. (Org.). Estudos em Negócios IV. 15ed. Rio de Janeiro: Mauad, 2005.

CASAROTTO FILHO, N.; PIRES, L. H. Redes de pequenas e médias empresas e desenvolvimento local: estratégias para a conquista da competitividade global com base na experiência italiana. 2. ed. São Paulo: Atlas, 2001.

CAStells, M.; CARDOSO, G. A Sociedade em Rede do Conhecimento à Ação Política. Imprensa Nacional - Casa da Moeda, 2005.

CASTRO, M. de; BULCAGOV, S.; HOFFMANN, V. E. Relacionamentos Interorganizacionais e Resultados: Estudo em uma Rede de Cooperação Horizontal da Região Central do Paraná. Revista de Administração Contemporânea, Curitiba, v. 15, n. 1, art. 2, p. 25-46, jan.-fev., 2011.

CAVALCANTI, M. Cooperativas e comunidades: o empreendimento compartilhado. In: CAVALCANTI, M. (Org.). Gestão social, estratégias e parcerias: redescobrindo essência da administração brasileira de comunidades para o terceiro setor. São Paulo: Saraiva, 2006.

CHAKRAVARTHY, B. S. Measuring strategic performance. Strategic Management Journal, v. 7, n. 5, p. 437-447, 1996.

CHAO, C. Y. Decision-making biases in the alliance life cycle: Implications for alliance failure. Management Decision, v. 49, n. 3, p. 350-364, 2011.

CHILD, J.; MACGRATH, R. G. Organizations Unfettered: Organizational form in an information - intensive economy. Academy of Management Journal, v. 44, n. 6, p. 1135 1148, 2001.

CICCHETTI, A. "Between Hierarchies \& Markets, The logic and the limits of network forms of organization" By Grahame F. Thompson, Oxford University Press, 2003. Journal of Management and Governance, v. 9, p. 199-203, 2005.

COELHO, D. B. Resenhas Bibliográficas: Franquias Brasileiras: Estratégia, Empreendedorismo, Inovação e Internacionalização. Revista de Administração Contemporânea - RAC, Rio de Janeiro, v. 17, n. 1, p. 126-127, jan.-fev., 2013.

COMBS, J. G.; KETCHEN, JR. D. J. Explaining interfirm cooperation and performance: Toward a reconciliation of predictions from the resource-based view and organizational economics. Strategic Management Journal, v. 20, p. 867-888, 1999. 
CORRAR, L. J.; PAULO, E.; DIAS FILHO, J. M. Análise Multivariada. São Paulo: Atlas, 2012.

CORSTEN, D.; GRUEN, T.; PEYINGAUS, M. The effects of supplier-to-buyer identification on operational performance - An empirical investigation of inter-organizational identification in automotive relationships. Journal of Operations Management, v.29, p.549-560, 2011.

CUNHA, C. R. da. Perspectivas Teóricas de Análise das Relações Interorganizacionais. In: Encontro de Estudos Organizacionais, 2002, Recife. Anais... Recife: Observatório da Realidade Organizacional: PROPAD/UFPE: ANPAD, 2002. 1 CD.

CUNHA, J. A. C.; LUIZ PASSADOR, J.; SOUZA PASSADOR, C. Recomendações e apontamentos para categorizações em pesquisas sobre redes interorganizacionais Cadernos EBAPE.BR, v. 9, Edição Especial, p.505-529, Rio de Janeiro, jul., 2011.

CUNHA, J. V. A. da; CORNACHIONE JUNIOR, E. B; MARTINS, G. de A. Doutores em Ciências Contábeis: Análise sob a Óptica da Teoria do Capital Humano. Revista de Administração Contemporânea - RAC, Curitiba, v. 14, n. 3, p. 532-55, Mai./Jun. 2010.

DAR-EL, E. Human Learning: from Learning Curves to Learning Organizations, New York: Springer, 2000.

DRUCKER, P. F. The Information Executives Truly Need. Harvard Business Review, Boston, v. 73, n. 1, p 54 - 62, jan-fev., 1995.

DUYSTERS G.; HAGEDOORN, J.; LEMMENS, C. The effect of alliance block membership on innovative performance. Revue d'Économie Industrielle, Programme National Persée, v. 103, n. 1, p. 59-70, 2003.

ECCLES, R. G. The Performance Measurement Manifesto. Harvard Business Review, Boston, v. 69, n. 1, p 131-137, jan.-fev., 1991.

FAYARD, P. O jogo da interação: informação e comunicação em estratégia. Caxias do Sul: EDUCS, 2000.

FERrEIRA, A. B. de H. Dicionário Aurélio da Língua Portuguesa. $5^{\mathrm{a}}$ ed. Curitiba: Positivo, 2010.

FERREIRA JR., A. N., SILVA, T. B. J.; LIMA FILHO, R. N. A Influência da Contabilidade Gerencial no Desempenho Econômico-Financeiro das Empresas de Cerâmica Vermelha de Senhor do Bonfim - BA. Revista de Gestão, Finanças e Contabilidade, UNEB, Salvador, v. 1, n. 1, p. 72-85, jan.- dez., 2011. 
FIALHO, S. Metodologia para construção e gestão de redes de cooperação interorganizacionais. In: TEIXEIRA, F. (Org.). Gestão de redes de cooperação interempresariais: em busca de novos espaços para o aprendizado e a inovação. Salvador: Casa da Qualidade, 2005.

FOMBRUN, C. J. Strategies for network research in organizations. Academy of Management Review, v. 7, n. 2, p. 280-291, 1982.

FORD, J. D.; SCHELlENBERG, D. A. Conceptual issues of linkage in the assessment of organizational performance. Academy of Management Review, v. 7, 1982.

FRANCO, M. J. B. Tipologia de Processos de Cooperação Empresarial: uma Investigação Empírica sobre o Caso Português. Revista de Administração Contemporânea, v. 11, n. 3, p. 149-176, jul.-set., 2007.

FREZATTI, F.; ROCHA, W.; NASCIMENTO, A. R. do; JUNQUEIRA, E. Controle Gerencial: Uma Abordagem da Contabilidade Gerencial no Contexto Econômico, Comportamental e Sociológico. São Paulo: Atlas, 2009.

FROEHLICH, C. As contribuições das relações interorganizacionais para o empreendedorismo internacional: um ensaio teórico. Revista de Gestão do Unilasalle, Canoas, v. 2, n. 2, set. 2013.

GEROLAMO, M. C.; CARPINETTI, L. C. R.; FLESCHUTZ, T.; SELIGER, G. Clusters e redes de cooperação de pequenas e médias empresas: observatório europeu, caso alemão e contribuições ao caso brasileiro. Gestão e Produção, São Carlos, v. 15, n. 2, p. 351-365, maio-ago. 2008.

GHISI, F. A.; MARTINELLI, D. P. Visão sistêmica das relações interorganizacionais: uma análise das redes de empresas. In: I Congresso Brasileiro de Sistemas, 2005, Ribeirão Preto. I Congresso Brasileiro de Sistemas, 2005.

GONÇALVES, L. S.; CUNHA, V. B.; NEVES JÚNIOR, I. J. das. Análise de resultados: um estudo exploratório sobre a correlação entre o índice Market-to-Book e os índices tradicionais de rentabilidade e EVA ${ }^{\circledR}$. Pensar Contábil, Rio de Janeiro, v.13, n.51, p. 17-25, maio-ago. 2011.

GRANDORI, A.; SODA, G. Inter-firms network: antecedents, mechanisms and forms. Organization Studies, v.16, n.2, p.183-214, 1995.

GRASSENI, M. Domestic multinationals and foreign-owned firms in Italy: Evidence from quantile regression. The European Journal of Comparative Economics, v. 7, n. 1, p. 61-86, 2010 . 
GRASSI, R. A. Cooperação interfirmas: a necessidade da construção de um "paradigma teórico". Ensaios FEE, Porto Alegre, v. 28, n. 1, p. 41-78, jul., 2007.

GRAY, B. \& WOOD, J. Collaborative alliances: Moving from practice to Theory. Applied Behavioral Science, v. 27, n. 1-2, mar. - jun., 1991.

GULATI, R.; NOHRIA, N.; ZAHEER, A. Strategic networks. Strategic Management Journal, v. 21, n. 3, p. 203-215, 2000.

GUNASEKARAN, A.; KOBU, B. Performance measures and metrics in logistics and supply chain management: a review of recent literature (1995-2004) for research and applications. International Journal of Production Research, v. 45, n. 12, p. 2819-2840, 2007.

HABER, S.; REICHEL, A. Identifying Performance Measures of Small Ventures-The Case of the Tourism Industry. Journal of Small Business Management, v. 43, n. 3, p. 257-286, 2005.

HAIR JR.; JOSEPH F.; BABIN, B.; MONEY, A. H.; SAMOUEL, P.; RIBEIRO, L. B. Fundamentos de métodos de pesquisa em administração. Porto Alegre: Bookman, 2005. HÅKANSSON, H., Industrial Technological Development: A Network Aproach, London: Routledge, 1987.

HARDIN, R. One for All: the Logic of Group Conflict. New Jersey: Princeton University, 1995.

HISRICH, R. D.; PETERS, M. P.; SHEPHERD, D. A. Empreendedorismo. $7^{\text {a }}$ Ed. Porto Alegre: Bookman, 2009.

HOQUE, Z. Linking environmental uncertainty to non-financial performance measures and performance: a research note. The British Accounting Review, v. 37, p. 471-481, 2005.

HUMAN, S. E.; PROVAN, K. G. An emergent theory of structure and outcomes in smallfirm strategic manufacturing network. Academy of Management Journal, v. 40, n. 2, p. 368-403, 1997.

IGARASHI, D. C. C.; ENSSLIN, S. R.; ENSSLIN, L.; PALADINI, E. P. A qualidade do ensino sob o viés da avaliação de um programa de pós-graduação em contabilidade: proposta de estruturação de um modelo híbrido. Revista de Administração, São Paulo, v.43, n.2, p.117-137, abr.-maio-jun., 2008.

ITTNER, C. D.; LARCKER, D. F. Assessing empirical research in managerial accounting: a value-based management perspective. Journal of Accounting and Economics, 32, p. 349410, 2001. 
JOHNSON, S. A.; HOUSTON, M. B. A reexamination of the motives and gains in joint ventures. Journal of Financial and Quantitative Analysis, v. 35, n. 1, p. 67-87, 2000.

KANTER, R. M.; BRINKERHOFF, D. Organizational performance: Recent developments in measurement. Annual Review of Sociology, v. 7, 1981.

KAPLAN, R. S.; NORTON, D. P. A estratégia em ação: Balanced Scorecard. 9. ed. Rio de Janeiro: Campus, 1997.

KLEIN, L. L.; PEREIRA, B. A. D.; QUATRIN, Denise Rossato. A Formação, o Desenvolvimento e o Fortalecimento de Redes de Cooperação. Revista da Micro e Pequena Empresa, Campo Limpo Paulista, v.8, n.3, p. 18 - 38, 2014.

KOZA, M.; LEWIN, A. Managing Partnerships and Strategic Alliances: Raising the Odds of Success. European Management Journal, v. 18, n. 2, p. 146-151, 2000.

KUNZLER, M. T.; BULGACOV, S. As estratégias competitivas e colaborativas e os resultados individuais e coletivos no associativismo rural em Quatro Pontes (PR). Revista de Administração Pública, Rio de Janeiro, v. 45, n. 5, p. 1363-1393, set. - out., 2011.

LARSON, A. Network dyads in entrepreneurial settings: a study of governance of exchange relationships. Administrative Science Quartely, v. 37, n. 1, p. 76-104, 1992.

LARSON, R.; FARBER, B. Estatística aplicada; tradução Luciene Ferreira Pauleti Vianna. 4 ed. São Paulo: Pearson Prentice Hall. 2010.

LAZZARINI, S. G. The impact of membership in competing alliance constellations: evidence on the operational performance of global airlines. Strategic Management Journal, v. 28, n. 4, p. 345-367, 2007.

LAZZARINI, S. G. The transition from alliance networks to multilateral alliances in the global airline industry. Brazilian Administration Review, v. 5, n. 1, p. 19-36, 2008.

LEE, S.; MONGE, P. The coevolution of multiplex communication networks in organizational communities. Journal of Communication, v. 61, n. 4, p. 758-779, 2011.

LENZI, F. C.; KIESEL, M. D. Empreendedor de Visão. São Paulo: Atlas, 2009.

LIEDHOLM, C.; MEAD, Donald. Small Enterprises and Economic Development The dynamics of micro and small enterprises. London: Routledge, 1999.

LIMA, J. B. Temas de pesquisa e desafios da produção científica sobre PME. Revista de Estudos Organizacionais, Maringá, v. 1, n.2, p. 27-47, 2000. 
LIN, Z. J.; YANG, H.; ARYA; B. Alliance partners and firm performance: resource complementarity and status association. Strategic Management Journal, v. 30, n. 9, p. 921940, 2009.

LIZOTE, S. A.; VERDINELLI, M. A. Explorando a relação entre capital intelectual e desempenho: Um estudo em empresas prestadoras de serviços contábeis. In: IX Congresso Anpcont, 2015, Curitiba. IX Congresso Anpcont, 2015.

LONGENECKER, J. G; MOORE, C. W; PETTY, W. J. Administração de Pequenas Empresas: Ênfase na Gerência Empresarial. São Paulo: Makron Books, 1997.

LORENZONI, G.; BADEN-FULLER, C. Creating a Strategic Center to Manage a Web of Partners. California Management Review, v. 37, n. 3, p. 146-163, 1995.

LOURENZANI, A. E. B. S.; SILVA, A. L. da; AZEVEDO, P. F. de. O Papel da Confiança na Construção de Ações Coletivas: um estudo em Redes de suprimentos de alimentos. In: XXX ENANPAD, 2006, Salvador - BA. Anais do XXX ENANPAD, 2006.

MACHADO, M. R.; MACHADO, M. A. V.; HOLANDA, F. M. A. Indicadores de desempenho utilizados pelo setor hoteleiro da cidade de João Pessoa/PB. Turismo - Visão e Ação, v. 9, n.3, p. 393-406, set.- dez. 2007.

MAGAlHÃES, J. M.; DAUDT, C. G.; PHONLOR, P. R. Vantagens proporcionadas às pequenas e médias empresas por meio da união em redes de cooperação no contexto do venture capital. Revista de Administração Contemporânea, v. 13, n. 4, p. 583-603, 2009.

MATITZ, Q. R. S. Aspectos Semânticos, Formais e Funcionais do conceito desempenho em estudos organizacionais e estratégia: Um modelo analítico. 2009. 309 f. Tese (Doutorado em Administração) - Programa de Pós-graduação em Administração, Universidade Federal do Paraná, Curitiba, 2009.

McADAM, R. BAILIE, B. Business performance measures and alignment impact on strategy: The role of business improvement models. International Journal of Operations \& Production Management, v. 22, n. 9, p. 972-996, 2002.

MERCHANT, H.; SCHENDEL, D. How do international joint ventures create shareholder value? Strategic Management Journal, v. 21, n. 7, p. 723-737, 2000.

MESQUITA, L. F.; LAZZARINI, S. G. Horizontal and vertical relationships in developing economies: implications for SMEs' access to global markets. Academy of Management Journal, v.51, n.2, p.359-380, 2008.

MEYER, C. How the Right Measures Help Teams Excel. Harvard Business Review, Boston, v.72, n. 3, p 95- 192, mai.-jun., 1994. 
MILES, R. E.; SNOW, C. C. Organizations: new concepts for new forms. California Management Review, v. 28, n. 3, p. 62-73, 1986.

MINTZBERG, H. The Structuring of Organizations. Prentice-Hall, 1979.

MOTTA, R. A busca da competitividade nas empresas. Revista de Administração de Empresas, São Paulo, v. 35, n.1, p. 12-16, mar.-abr., 1995.

MÜLLER-SEITZ, G. Leadership in interorganizational networks: a literature review and suggestions for future research. International Journal of Management Reviews, v. 14, n. 4, p. 428-433, 2011.

NEELY, A.; GREGORY, M.; PLATTS, K. Performance measurement system design: A literature review and research agenda. International Journal of Operations \& Production Management, v. 15, n. 4, p. 80-116, 1995.

NIELSEN, R. P. Cooperative Strategy. Strategic Management Journal. v. 9, n. 5, p. 475492, set- out, 1988.

OLAVE, M. E. L.; AMATO NETO, J. Redes de cooperação produtiva: uma estratégia de competitividade e sobrevivência para pequenas e médias empresas. Gestão e Produção, v.8, n.3, p.289-303, dez., 2001.

OLEIRO, W. N; DAMEDA, A. das N; VICTOR, F. G. O uso da informação contábil na gestão de micro e pequenas empresas atendidas pelo programa de extensão empresarial NEE/FURG. SINERGIA, Rio Grande, v. 11, n. 1, p. 37-47, 2007.

OlIVEIRA, A. L. de; REZENDE, D. C. de; CARVALHO, C. C. de. Redes Interorganizacionais Horizontais Vistas como Sistemas Adaptativos Complexos Coevolutivos: o Caso de uma Rede de Supermercados. Revista de Administração Contemporânea, Curitiba, v. 15, n. 1, p. 67-83, jan.- fev., 2011.

OLIVEIRA, V. M. de; CÂNDIDO, G. A. As Contribuições dos conceitos e modelos de Redes Organizacionais no setor varejista: Um estudo exploratório em pequenos supermercados no estado da Paraíba. Revista Eletrônica de Administração, Edição 64, v. 15, n. 3, set. - dez., 2009.

OLIVER, C. Determinants of interorganizational relationships: integration and future directions. Academy of Management Review, v. 15, n. 12, p. 241-265. 1990.

OLSON, E. M.; SLATER, S. F. The balanced scorecard, competitive strategy, and performance. Business Horizons, maio-jun., 2002.

OLSON, M. A lógica da ação coletiva. São Paulo, EDUSP, 1999. 
PACAGNAN, M.N. Alianças estratégicas e redes colaborativas como alternativa. Revista de Gestão USP, v.13, n. especial, p. 19-30, 2006.

PELHAM, A. M.; WILSON, D. T. A longitudinal study of the impact of market structure, firm structure, strategy, and market orientation culture on dimensions of small- firm performance. Journal of Academy of Marketing Science, v. 24, n.1, p. 27-43, 1996.

PEREIRA, R. de C. de F. Marketing em Redes de Cooperação: um Estudo de Caso em uma Rede Varejista. In: Anais do Encontro de Estudos Organizacionais, 2004.

PEREIRA, B. A. D.; VENTURINI, J. C.; VISENTINI, M. S. Estruturação de relacionamentos horizontais em rede. Revista Eletrônica de Administração, v. 12, n. 5, p. 1-20, 2006.

PERIN, M. G.; SAMPAIO, C. H. Performance empresarial: uma comparação entre indicadores subjetivos e objetivos. In: Anais 23 Encontro Nacional dos Programas de Pós Graduação e Pesquisa em Administração, 1999.

PLOYHART, R. E.; NYBERG, A. J.; REILLY, G.; MALTARICH, M. A. Human capital is dead; long live human capital resources! Journal of Management, v. 40, n. 2, p. 371-398, fev., 2014.

PODOLNY, J. M.; PAGE, K. L. Network forms of organization. Annual Review of Sociology, v.24, p.57-76, 1998.

POLETTO, C. A.; DUARTE, M. A. D. de A.; MATA, W. Gestão compartilhada de P\&D: o caso da Petrobras e a UFRN. Revista de Administração Pública, Rio de Janeiro, v. 45, n. 4, p. 1095-1117, set. - out., 2011.

PRAHALAD, C. K.; RAMASWAMY, V. O futuro da competição: como desenvolver diferenciais inovadores em parcerias com clientes. Rio de Janeiro: Elsevier, 2004.

PRENKERT, F.; HALLÉN, L. Conceptualising, delineating and analysing business networks. European Journal of Marketing, v.40, n.3-4, p.384-407, 2006.

PROVAN, K. G.; SYDOW, J. Evaluating inter-organizational relationships. In: CROPPER, S.; et al. The Oxford Handbook of Inter-organizational relations. Oxford: Oxford University Press, 2008.

PROVAN, K. G.; FISH, A.; SYDOW, J. Interorganizational networks at the network level: a review of the empirical literature on whole networks. Journal of Management, v.33, n.3, p.479-516, 2007. 
REIS, J. A. dos; EL-KOUBA, A.; QUANDT, C. O.; Cruz, J. A. W.; MARTINS, T. S. Cooperação e desenvolvimento: estudo de caso em uma rede de cooperação. Revista Gerenciais, São Paulo, v. 7, n. 1, p. 21-28, 2008.

RING, P. S.; VAN DE VEN, A. H. Developmental Processes of Cooperative Interorganizational Relationships. The Academy of Management Review, v. 19, n. 1, p. 90118, jan., 1994.

SÁNCHEZ, M. A. M.; VALENTÍN, E. M. M. Medidas del rendimiento en las relaciones cooperativas: el efecto del cumplimiento de los objetivos en el grado de satisfacción de los socios. Revista Europea de Dirección y Economía de la Empresa, v. 19, n. 1, p. 147-164, 2010 .

SANTOS, L. C. B. dos. VASCONCELOS, F. N. P. de. COLARES, A. C. V. MOREIRA, M. A. Profissionais da contabilidade engajados no auxílio gerencial às micro e pequenas empresas brasileiras. Revista Brasileira de Contabilidade, n. 210, nov.- dez., 2014.

SANTOS, J. B. Uma proposta de conceituação e representação do desempenho empresarial. Dissertação de Mestrado. 2008. 126f. Escola de Administração de Empresas de São Paulo da Fundação Getúlio Vargas, São Paulo, 2008.

SCHERMERHORN J. R.; Determinants of Interorganizational Cooperation. The Academy of Management Journal, v. 18, n. 4, p. 846-856, dec., 1975.

SCHLITHLER, C. R. B. Redes Intersetoriais de Desenvolvimento Comunitário. Instituto para o Desenvolvimento do Investimento Social, 2010.

SEBRAE. Casos de Sucesso de Redes e Centrais de Negócios. Brasília - DF, 2014.

SERRA, F. R.; FERREIRA, M. P.; Emerging determinants of firm performance: A case study research examining the strategy pillars from a resource-based view. The Journal of the Iberoamerican Academy of Management, v. 8 n. 1, p. 7-24, 2010.

SIEGEL, S.; CASTELLAN, N. J. Estatística não-paramétrica para ciências do comportamento. São Paulo: Bookman, 2006.

SILVA FILHO, G. M. da. Nível de conhecimento dos profissionais de contabilidade em relação ao sistema público de escrituração digital por meio da teoria de resposta ao item. Dissertação de Mestrado. 2015. 104f. Programa MultiInstitucional e Inter-Regional de PósGraduação em Ciências Contábeis da Universidade de Brasília, Universidade Federal da Paraíba e Universidade Federal do Rio Grande do Norte, João Pessoa, 2015.

SILVA, C. M. M.; SCHROEDER, L.; HOFFMANN, V. E. As relações interorganizacionais como mecanismos de desenvolvimento. UniFAE Inteligentia, 2005. 
SILVERMAN, B. S.; BAUM, J. A. C. Alliance-based competitive dynamics. Academy of Management Journal, v.45, n.4, p.791-806, 2002.

SIRMON, D. G.; HITT, M. A.; ARREGLE, J.; CAMPBELL, J. T. The Dynamic Interplay of Capability Strengths And Weaknesses: Investigating The Bases Of Temporary Competitive Advantage. Strategic Management Journal, v. 31, n. 13, p. 1386- 1409, 2010.

SIU, W.S. An institutional analysis of marketing practices of small and medium-sized enterprises (SMEs) in China, Hong Kong and Taiwan. Entrepreneurship and Regional Development, v.17, n.1, p. 65-88, 2005.

SOUTES, D. O.; GUERREIRO, R. Estágios evolutivos da Contabilidade Gerencial em empresas brasileiras. In: XXXI Encontro da ANPAD. Anais... Rio de Janeiro, 2007.

SOUZA, G. H. S. de; LIMA, N. C.; COELHO, J. A. P. de M.; OLIVEIRA, S. V. W. B. de; MILITO, C. M. A Influência das Redes de Cooperação no Desenvolvimento de Micro e Pequenas Empresas (MPES). In: XVII SEMEAD Seminários em Administração, São Paulo. Anais... 2014.

SOUZA, M. M.; MORAES, A. F. de O.; NASCIMENTO, J. P. de B. SILVEIRA, P. R.; SOARES, K. G. R. O comportamento empreendedor dos contabilistas: um estudo exploratório. In: X Simpósio de Excelência em Gestão e Tecnologia. Anais... Gestão e tecnologia para a competitividade, 2013.

STEERS, R. M. Problems in the measurement os organizational effectiveness. Administrative Science Quartely, v. 20, 1975.

TAVARES, W. CASTRO, C. C. de. Relações Interorganizacionais no estabelecimento de uma aglomeração produtiva. Revista de Administração FACES Journal, Belo Horizonte, v. 11, n. 4, p. 31-50, out.- dez., 2012.

TAVARES, W. CASTRO, C. C. de. Relações Interorganizacionais no estabelecimento de uma aglomeração produtiva. Revista de Administração FACES Journal, Belo Horizonte, v. 11, n. 4, p. 31-50, out.- dez. 2012.

TEIXEIRA, E. B.; VITCEL, M. S.; BEBER, M C. Cooperação Estratégica, Redes de Cooperação e Desenvolvimento Regional: o caso Unijuí/Sedai. Desenvolvimento em Questão, Editora Unijuí, ano 5, n. 10, p. 187-210, jul. - dez., 2007.

TODEVA, E.; KNOKE, D. Strategic alliances and models of collaboration. Management Decision, v.43, n.1, p.123-148, 2005.

TONDOLO, V. A. G.; SCHNEIDER, L. C. Vantagens logísticas cadeia de valor na rede de empresas: o caso de uma rede gaúcha de pequenas farmácias. Alcance - UNIVALI, v. 12, n.2, p. 143 - 160, maio-ago. 2005. 
TURETA, C.; PAÇO-CUNHA, E. Emergência e constituição de redes interorganizacionais de pequenas e médias empresas: Um estudo de caso no contexto brasileiro. Revista Eletrônica de Gestão Organizacional, v.6, n.1, 2008.

TURRINI, A.; CRISTOFOLI, D.; FROSINI, F.; NASI G. Networking literature about determinants of network effectiveness. Public Administration, v. 88, n. 2, p. 528-550, 2009.

UTKIN, A. Globalization: Process and Interpretation. Russian Social Science Review, v. 43, n. 6, p. 4-37, nov.- dez., 2002.

VARRICHIO, P.; DIOGENES, D.; JORGE, A.; GARNICA, L. Collaborative networks and sustainable business: a case study in the Brazilian system of innovation. Procedia - Social and Behavioral Sciences, v. 52, p. 90-99, 2012.

VENKATRAMAN, N.; RAMANUJAM, V. Measurement of Business Performance in Strategy Research: A Comparison of Approaches. Academy of Management Review, v. 11, n. 4, p. 801-814, 1986.

VERSCHOORE FILHO, J. R. de S. Redes de Cooperação Interorganizacionais: A Identificação de Atributos e Benefícios para um Modelo de Gestão. 2006. 253 f. Tese (Doutorado em Administração) - Programa de Pós-Graduação em Administração, Universidade Federal do Rio Grande do Sul, Porto Alegre, 2006.

VERSCHOORE, J. R.; BALESTRIN, A. Fatores Competitivos das Empresas em Redes de Cooperação. In: XXX ENANPAD, 2006, Salvador - BA. Anais do XXX ENANPAD, 2006.

VERSCHOORE, J. R.; BALESTRIN, A. Ganhos competitivos das empresas em redes de cooperação. Revista de Administração Eletrônica, São Paulo, v.1, n.1, art.2, jan.-jun., 2008.

WEGNER, D. Governança, Gestão e Capital Social em Redes Horizontais de Empresas: Uma análise de suas relações com o desempenho das empresas participantes. 2011. $203 \mathrm{f}$. Tese (Doutorado em Administração) - Programa de Pós-graduação em Administração, Universidade Federal do Rio Grande do Sul, Porto Alegre, 2011.

WEGNER, D.; ALIEVI, R. M.; BEGNIS, H. S. M. The Life Cycle of Small-firm Networks: An Evaluation of Brazilian Business Networks. BAR, Rio de Janeiro, v. 12, n. 1, art. 3, pp. 39-62, jan.-mar., 2015.

WEGNER, D.; WITTMANN, M. L.; DOTTO, D. M. R. Redes de empresas no Rio Grande do Sul: uma análise de resultados competitivos e fatores de desenvolvimento. Revista Eletrônica de Gestão Organizacional, v. 4, n. 1, jan.-abr., 2006. 
WEGNER, D; CALlADO, A. A. C.; AGNES, J. I. Redes de Cooperação, Franquias e Empresas Individuais: Uma Análise Comparativa do Desempenho Empresarial. In: XVII Simpósio de Administração da Produção, Logística e Operações Internacionais, São Paulo. Anais... 2014.

WEGNER, D; MAEHLER, A. E. Desempenho de empresas participantes de rede interorganizacionais: analisando a influência do capital social e da capacidade absortiva. Revista Gestão e Planejamento, Salvador, v. 13, n. 2, p. 191-211, maio-ago., 2012.

WHETTEN, D. A. Interorganizational relations: A review of the field. Journal of Higher Education, v.52, n.1, p.1-28, 1981.

WILDEMAN, L. Alliances and networks: the next generation. International Journal of Technology Management, Bristol, v.15, n.1-2, p.96-108, Fall, 1998.

WRIGHT, R. W.; ETEMAD, H. SMEs and the global economy. Journal of International Management, v.7, p. 151-154, 2001.

ZANCAN, C. Redes de Cooperação: Um Estudo de Relações Interorganizacionais na Associação dos Produtores de Vinhos Finos do Vale dos Vinhedos (APROVALE). 2010. 287 f. Tese (Doutorado em Administração) - Programa de Pós-Graduação em Administração, Universidade de Brasília, Brasília, 2010.

ZANCAN, C.; SANTOS, P. da C. F. dos; COSTA, A. C. S.; CRUZ, N. J. T. da. Condicionantes de consolidação de redes de cooperação interorganizacional: um estudo de caso sobre o Rio Grande do Sul. Revista de Administração Pública, Rio de Janeiro v. 47, n. 3, p. 647-669, maio-jun., 2013.

ZEN, A. C.; WEGNER, D. A Troca de Conhecimento nas Redes Interorganizacionais: o caso da Rede Gaúcha de Incubadoras e Parques Tecnológicos. In: XI Semead, 2008, São Paulo. XI Semead - Empreeendedorismo em Organizações, 2008. 


\section{APÊNDICE A: QUESTIONÁRIO}

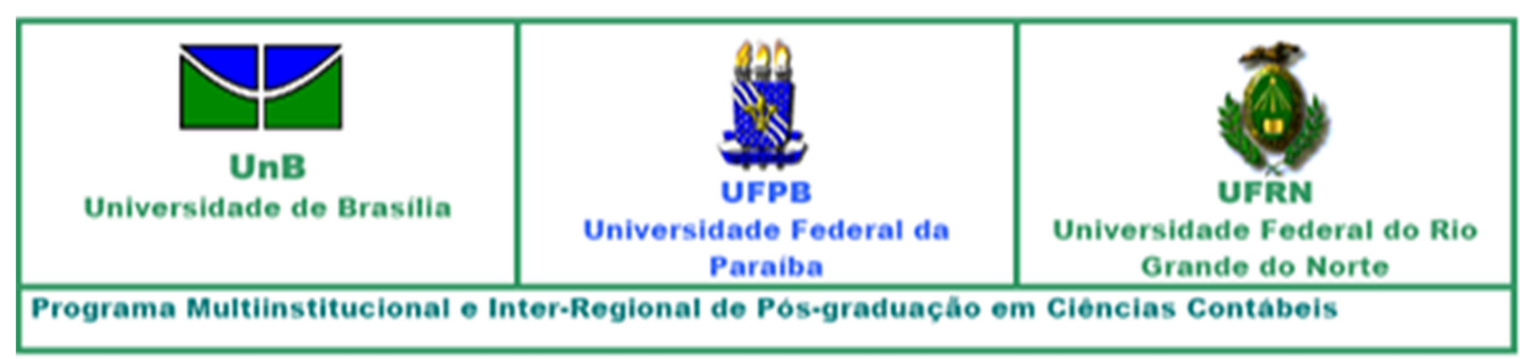

\section{PROGRAMA MULTIINSTITUCIONAL E INTER-REGIONAL DE PÓS-GRADUAÇÃO EM CIÊNCIAS CONTÁBEIS}

PESQUISA SOBRE O DESEMPENHO ORGANIZACIONAL DAS MICRO E PEQUENAS EMPRESAS: ESTUDO COMPARATIVO ENTRE REDES DE COOPERAÇÃO E EMPRESAS INDEPENDENTES

Prezado participante (a),

Para a realização desta pesquisa, solicito sua colaboração participando deste estudo mediante o preenchimento de um questionário individual.

$\mathrm{O}$ referido questionário faz parte de uma pesquisa para conclusão do mestrado em Ciências Contábeis, o qual pretende analisar o desempenho de micro e pequenas empresas que atuam no mercado como participantes de redes de cooperação ou independente de qualquer rede.

A sua participação na pesquisa é voluntária, não serão solicitadas informações financeiras da sua empresa e suas respostas são completamente anônimas, sendo apenas os pesquisadores diretamente envolvidos no projeto os que terão acesso aos dados.

Por oportuno, agradecemos a vossa preciosa colaboração e nos colocamos à disposição para outros esclarecimentos que se façam necessários.

\section{PARTE I - PERFIL DA EMPRESA}

1- Há quanto tempo esta empresa atua no mercado? anos

2- Quantas pessoas trabalham na empresa? (incluindo familiares) pessoas

3 - Qual o setor de atuação da empresa?

( ) Varejo de materiais de construção

( ) Varejo de produtos farmacêuticos

( ) Mercados 
( ) Produtos agrícolas

( ) Varejo de Móveis

( ) Serviços

( ) Outro: (por favor, especifique)

4 - Como a sua empresa atua no mercado?

( ) Participando de Rede de Cooperação （ ） Independente

Se respondeu "Independente" na questão anterior, por gentileza, seguir para parte II do questionário.

5 - Há quanto tempo participa de uma rede de cooperação? anos

6 - Qual a rede de cooperação sua empresa participa?

\section{PARTE II - EMPRESA EM COMPARAÇÃO COM OS CONCORRENTES}

1 - Satisfação dos clientes: Na sua percepção, como foi o desempenho da sua empresa, no último ano, quando comparado à média dos concorrentes do setor?

$\begin{array}{ccccc}\text { Muito } & \text { Pior que } & \text { Igual à } & \text { Melhor a } & \begin{array}{c}\text { Muito } \\ \text { Melhor } \\ \text { Pior que } \\ \text { a média }\end{array} \\ \text { a média } & \text { média } & \text { que média } & \begin{array}{c}\text { que a } \\ \text { média }\end{array}\end{array}$

\begin{tabular}{|c|c|c|c|c|c|}
\hline $\begin{array}{l}\text { Valor agregado para o cliente } \\
\text { (pacote de produtos e serviços) }\end{array}$ & $($ ) & $(\quad)$ & $(\quad)$ & $(\quad)$ & $($ ) \\
\hline $\begin{array}{l}\text { Número de reclamações de } \\
\text { clientes }\end{array}$ & () & () & () & () & () \\
\hline $\begin{array}{l}\text { Fidelidade dos clientes (taxa de } \\
\text { recompra) }\end{array}$ & $(\quad)$ & $(\quad)$ & $(\quad)$ & $(\quad)$ & $(\quad)$ \\
\hline Retenção de novos clientes & $($ ) & $(\quad)$ & $(\quad)$ & $(\quad)$ & $($ ) \\
\hline Satisfação geral dos clientes & $(\quad)$ & $(\quad)$ & $(\quad)$ & $(\quad)$ & $(\quad)$ \\
\hline
\end{tabular}


2 - Satisfação dos Funcionários: Na sua percepção, como foi o desempenho da sua empresa, no último ano, quando comparado à média dos concorrentes do setor?

\begin{tabular}{|c|c|c|c|c|}
\hline $\begin{array}{l}\text { Muito } \\
\text { Pior que } \\
\text { a média }\end{array}$ & $\begin{array}{l}\text { Pior que } \\
\text { a média }\end{array}$ & $\begin{array}{l}\text { Igual à } \\
\text { média }\end{array}$ & $\begin{array}{c}\text { Melhor } \\
\text { que a } \\
\text { média }\end{array}$ & $\begin{array}{l}\text { Muito } \\
\text { Melhor } \\
\text { que a } \\
\text { média }\end{array}$ \\
\hline
\end{tabular}

\begin{tabular}{|c|c|c|c|c|c|}
\hline Rotatividade dos funcionários & $(\quad)$ & $(\quad)$ & $(\quad)$ & $(\quad)$ & $(\quad)$ \\
\hline $\begin{array}{l}\text { Investimento no desenvolvimento } \mathrm{e} \\
\text { treinamento dos funcionários }\end{array}$ & $(\quad)$ & () & $(\quad)$ & $(\quad)$ & () \\
\hline Política de Remuneração e Benefícios & & $(\quad)$ & $(\quad)$ & $(\quad)$ & $(\quad)$ \\
\hline Plano de Carreira & $(\quad)$ & $(\quad)$ & $(\quad)$ & $(\quad)$ & $(\quad)$ \\
\hline Clima organizacional & () & () & () & () & () \\
\hline Satisfação geral dos funcionários & () & () & () & $(\quad)$ & () \\
\hline
\end{tabular}

3 - Na sua percepção, como foi o crescimento da sua empresa, no último ano, quando comparado à média dos concorrentes do setor?

$\begin{array}{ccccc}\text { Muito } & \text { Pior que } & \text { Igual à } & \begin{array}{c}\text { Melhor } \\ \text { que a }\end{array} & \begin{array}{c}\text { Muito } \\ \text { Melhor } \\ \text { Pior que } \\ \text { a média }\end{array} \\ \text { a média } & \text { média } & \begin{array}{c}\text { média } \\ \text { média }\end{array}\end{array}$

\begin{tabular}{|c|c|c|c|c|c|}
\hline $\begin{array}{l}\text { Crescimento da participação de } \\
\text { mercado }\end{array}$ & $(\quad)$ & $(）$ & $(\quad)$ & $(\quad)$ & $(\quad)$ \\
\hline Crescimento do ativo total & $(\quad)$ & $(\quad)$ & $(\quad)$ & $(\quad)$ & $(\quad)$ \\
\hline Crescimento do faturamento & $(\quad)$ & $(\quad)$ & $(\quad)$ & $(\quad)$ & $(\quad)$ \\
\hline Crescimento do lucro líquido & () & $(\quad)$ & $(\quad)$ & $(\quad)$ & $(\quad)$ \\
\hline $\begin{array}{l}\text { Crescimento do número de } \\
\text { funcionários }\end{array}$ & $(\quad)$ & () & () & & () \\
\hline
\end{tabular}

4 - Na sua percepção, como foi a lucratividade da sua empresa, no último ano, quando comparado à média dos concorrentes do setor?

\begin{tabular}{|c|c|c|c|}
\hline $\begin{array}{l}\text { Muito } \\
\text { Pior que } \\
\text { a média }\end{array}$ & $\begin{array}{l}\text { Pior que } \\
\text { a média }\end{array}$ & $\begin{array}{l}\text { Igual à } \\
\text { média }\end{array}$ & $\begin{array}{l}\text { Melhor } \\
\text { que a } \\
\text { média }\end{array}$ \\
\hline
\end{tabular}

\begin{tabular}{llllll}
\hline Retorno sobre o capital investido & $(\quad)$ & $($ ) & $($ ) & $($ ) & $($ ) \\
Lucro líquido sobre as vendas & $(\quad)$ & $(\quad)$ & $(\quad)$ & $(\quad)$ & $(\quad)$ \\
\hline
\end{tabular}




\section{PARTE III - EMPRESA EM COMPARAÇ̃̃O AO ANO ANTERIOR}

1 - Como foi o crescimento da sua empresa, em 2014, quando comparado ao ano de 2013 ? (Caso a empresa tenha menos de 2 anos, por gentiliza, marcar "Não se aplica")

Muito Pior Igual Melhor $\begin{gathered}\text { Muito } \\ \text { Melhor }\end{gathered}$ año se
aplica

\begin{tabular}{|c|c|c|c|c|c|c|}
\hline $\begin{array}{l}\text { Crescimento da participação } \\
\text { de mercado }\end{array}$ & $(\quad)$ & () & $($ ) & & $(\quad)$ & $(\quad)$ \\
\hline Crescimento do lucro líquido & $(\quad)$ & $(\quad)$ & $(\quad)$ & $(\quad)$ & $(\quad)$ & $(\quad)$ \\
\hline
\end{tabular}

2 - Como foi a lucratividade da sua empresa, em 2014, quando comparado ao ano de 2013 ? (Caso a empresa tenha menos de 2 anos, por gentiliza, marcar "Não se aplica")

Muito
Pior Pior Igual Melhor $\begin{gathered}\text { Muito } \\ \text { Melhor ano se } \\ \text { aplica }\end{gathered}$

$\begin{aligned} & \text { Retorno sobre } \\ & \text { investido }\end{aligned}$
$\begin{aligned} & \text { Lucro capital } \\ & \text { vendas }\end{aligned}$

\section{PATER IV - DESEMPENHO DA SUA EMPRESA EM GERAL}

Muito
Pior Pior Igual Melhor $\begin{gathered}\text { Muito } \\ \text { Melhor }\end{gathered}$

Na sua percepção, como foi o desempenho geral da sua empresa, no último ano, quando comparado à média dos concorrentes do setor?

$\mathrm{Na}$ sua percepção, como foi o desempenho geral da sua empresa, no último ano comparado ao resultado do ano anterior? 
PARTE V - COMPETITIVIDADE

Discordo

Concordo

totalmente

Totalmente

\begin{tabular}{|c|c|c|c|c|c|}
\hline $\begin{array}{l}\text { Na região de atuação da minha } \\
\text { empresa há vários } \\
\text { concorrentes que estão bem } \\
\text { estabelecidos há anos. }\end{array}$ & 1 & 2 & 3 & 4 & 5 \\
\hline $\begin{array}{l}\text { Há um grande número de } \\
\text { concorrentes que entraram } \\
\text { recentemente na região de } \\
\text { atuação da minha empresa. }\end{array}$ & 1 & 2 & 3 & 4 & 5 \\
\hline $\begin{array}{l}\text { Tenho vários concorrentes que } \\
\text { focam no mesmo perfil de } \\
\text { clientes. }\end{array}$ & 1 & 2 & 3 & 4 & 5 \\
\hline $\begin{array}{l}\text { No nosso segmento, todos os } \\
\text { serviços que um concorrente } \\
\text { oferece podem ser imitados } \\
\text { pela concorrência em curto } \\
\text { período de tempo. }\end{array}$ & 1 & 2 & 3 & 4 & 5 \\
\hline
\end{tabular}

\section{PARTE VI - ASPECTOS ASSOCIADOS ÀS INFORMAÇÕES CONTÁBEIS}

1- Os serviços contábeis que são prestados à empresa são desenvolvidos por:

( ) Empresas ou contadores terceirizados

( ) Contador/profissional pertencente ao quadro funcional da empresa

2- Quanto às funções exercidas pelo contador da sua empresa:

Discordo

Concordo

totalmente

Totalmente

\begin{tabular}{|c|c|c|c|c|c|}
\hline $\begin{array}{l}\text { Elaboração da folha de } \\
\text { pagamento e cálculo das } \\
\text { obrigações trabalhistas. }\end{array}$ & 1 & 2 & 3 & 4 & 5 \\
\hline Cálculo das obrigações fiscais. & 1 & 2 & 3 & 4 & 5 \\
\hline $\begin{array}{l}\text { Elaboração das demonstrações } \\
\text { contábeis. }\end{array}$ & 1 & 2 & 3 & 4 & 5 \\
\hline Elaboração de relatórios de & 1 & 2 & 3 & 4 & 5 \\
\hline
\end{tabular}




\begin{tabular}{llllll}
\hline custos & & & & & \\
\hline Elaboração de orçamentos & 1 & 2 & 3 & 4 & 5 \\
\hline $\begin{array}{l}\text { Controle financeiro (fluxo de } \\
\text { caixa, contas a receber, contas } \\
\text { a pagar, etc.) }\end{array}$ & 1 & 2 & 3 & 4 & 5 \\
\hline
\end{tabular}

3- Analise as situações e marque de acordo com a realidade observada na sua empresa:

Discordo

totalmente
Concordo

Totalmente

Você percebe que seus custos
estão superando seus ganhos
obtidos. Dessa forma, marca
uma reunião com seu contador
para discutir possibilidades de
redução de custos.
Você começou a vender uma
nova linha de produtos e
percebe que tem dificuldade
para estabelecer o preço de
venda. Dessa forma, você
entra em contato com seu
contador para que o mesmo o
auxilie na formação de preço
dos produtos.
Você constata que a
rotatividade dos seus estoques
está variando de acordo com a
época do ano e percebe que
em determinados períodos do
ano é necessário tomar
medidas de controle de
estoques.
consulta seu contador para que
sejam tomadas medidas de
solução.
Os seus negócios estão indo
bem e você tem pretensões em
ampliá-lo. Dessa forma,
consulta seu contador para que
o mesmo possa lhe auxiliar na
melhor forma de implementar
esse investimento.


4- Analise as situações e marque conforme procederia:

Discordo

Concordo

totalmente

Totalmente

\begin{tabular}{|c|c|c|c|c|c|}
\hline $\begin{array}{l}\text { As informações fornecidas } \\
\text { pelo contador são utilizadas } \\
\text { para fins gerenciais. }\end{array}$ & 1 & 2 & 3 & 4 & 5 \\
\hline $\begin{array}{l}\text { Caso o contador produzisse } \\
\text { relatórios que lhe fornecesse a } \\
\text { situação da empresa no } \\
\text { mercado e informações úteis } \\
\text { para seu gerenciamento, você } \\
\text { estaria disposto a abrir } \\
\text { informações do } \\
\text { empreendimento. }\end{array}$ & 1 & 2 & 3 & 4 & 5 \\
\hline $\begin{array}{l}\text { Caso o governo simplificasse } \\
\text { os impostos de modo que você } \\
\text { mesmo fosse capaz de calcular } \\
\text { e efetuar os pagamentos } \\
\text { referentes às obrigações } \\
\text { fiscais e trabalhistas, você } \\
\text { manteria o seu contrato com o } \\
\text { contador. }\end{array}$ & 1 & 2 & 3 & 4 & 5 \\
\hline $\begin{array}{l}\text { Se o contador produzisse } \\
\text { relatórios semanais que lhe } \\
\text { permitisse um controle das } \\
\text { operações e o conhecimento } \\
\text { de como está indo o seu } \\
\text { negócio, você estaria disposto } \\
\text { a pagar a mais por seus } \\
\text { serviços. }\end{array}$ & 1 & 2 & 3 & 4 & 5 \\
\hline
\end{tabular}

\section{PARTE VII - PERFIL DO RESPONDENTE}

1- Qual das opções a seguir, melhor descreve sua posição na sua empresa?

( ) Sócio-proprietário ( ) Gerente ( ) Outro:

2- Sexo:

( ) Masculino ( ) Feminino

3- Idade: 
4 - Escolaridade:

( ) Ensino Fundamental

( ) Ensino Médio

Graduação. Qual?

Pós-graduação. Qual?

5. Situação da escolaridade:

( ) Completo ( ) Incompleto

6 - Há quanto tempo atua neste setor? anos

7 - Há quanto tempo está nesta empresa? ___ anos

8 - Há quanto tempo está neste cargo? anos

Obrigada por contribuir com a pesquisa.

Agradecemos seu auxílio e ficamos à disposição em caso de dúvidas.

Atenciosamente,

Prof. Dr. Aldo Leonardo Cunha Callado

Professor do Departamento de Finanças e Contabilidade

Universidade Federal da Paraíba (UFPB)

E-mail: aldocallado@yahoo.com.br

Telefone: (83) 99928-8236

Ana Karla de Lucena Gomes

Mestranda em Ciências Contábeis Unb/ UFPB/UFRN

E-mail: aklucenagomes@gmail.com

Telefone: (83) 98791-7760 